\title{
Geochronology and lithogeochemistry of granitoid rocks from the central part of the Central plutonic belt, New Brunswick, Canada: implications for Sn-W-Mo exploration
}

\author{
Reginald A. Wilson ${ }^{1^{*}}$ and SANDra L. KAMO ${ }^{2}$ \\ 1. New Brunswick Department of Energy and Mines, Geological Surveys Branch, 2574 Route 180, \\ South Tetagouche, New Brunswick E2A 7B8, Canada \\ 2. Jack Satterly Geochronology Laboratory, Department of Earth Sciences, University of Toronto, \\ 22 Russell Street, Toronto, Ontario M5S 3B1, Canada \\ *Corresponding author $<$ reg.wilson@gnb.ca $>$
}

Date received: 06 November 2015 g Date accepted: 03 February 2016

\begin{abstract}
The central part of the Central plutonic belt in New Brunswick is underlain by numerous plutons of calc-alkaline, foliated and unfoliated granite that intrude Cambrian to Early Ordovician metasedimentary rocks. U-Pb (zircon) dating demonstrates that granites range in age from Middle Ordovician to Late Devonian, although most are late Silurian to Early Devonian. An age of $467 \pm 7 \mathrm{Ma}$ has been obtained on the foliated McKiel Lake Granite, whereas unfoliated intrusions yield ages of 423.2 \pm 3.2 Ma (Bogan Brook Granodiorite), 420.7 +1.8/-2.0 Ma (Nashwaak Granite), $419.0 \pm 0.5 \mathrm{Ma}$ (Redstone Mountain Granite), $416.1 \pm 0.5 \mathrm{Ma}$ (Beadle Mountain Granite), $415.8 \pm 0.3 \mathrm{Ma}$ (Juniper Barren Granite), 409.7 $\pm 0.5 \mathrm{Ma}$ (Lost Lake Granite), and 380.6 $\pm 0.3 \mathrm{Ma}$ (Burnthill Granite). All plutons exhibit mixed arc-like and within-plate geochemical signatures, although the Redstone Mountain and Burnthill granites are dominantly within-plate type. Trace element data reveal a close overall geochemical similarity between Ordovician and Silurian - Devonian plutons, indicating that all were generated by partial melting of similar crustal sources and/or share a similar petrogenesis. Late Silurian to Early Devonian plutons mainly comprise biotite and/or muscovite-bearing, peraluminous granite and are considered prospective for granophile-element mineralization. All plutons contain Sn well in excess of the granite global average abundance, and several contain average tin values comparable to productive stanniferous granites elsewhere. The Burnthill, Lost Lake, Beadle Mountain and Nashwaak granites are geochemically most evolved and enriched in Sn and W. The Burnthill Granite in particular has experienced late-stage hydrothermal processes that have resulted in local enrichments of these elements.
\end{abstract}

\begin{abstract}
RÉSUMÉ
La portion centrale de la ceinture plutonique centrale du NouveauBrunswick comporte de nombreux plutons de granites calco-alcalins, foliés et non foliés, qui font intrusion dans des roches métasédimentaires datant du Cambrien à l'Ordovicien précoce. Une datation UPb sur zircon révèle que les granites datent de l'Ordovicien moyen au Dévonien tardif, mais du Silurien tardif au Dévonien précoce pour la plupart. Le granite folié du lac McKiel est âgé de $467 \pm 7 \mathrm{Ma}$, alors que les intrusions non foliées remontent à 423,2 \pm 3,2 Ma (granodiorite du ruisseau Bogan), à 420,7 + 1,8/-2,0 Ma (granite de Nashwaak), à 419,0 $\pm 0,5 \mathrm{Ma}$ (granite du mont Redstone, à $416,1 \pm 0,5 \mathrm{Ma}$ (granite du mont Beadle), à 415,8 \pm 0,3 Ma (granite de Juniper Barren), à 409,7 $\pm 0,5 \mathrm{Ma}$ (granite du lac Lost) et à 380,6 $\pm 0,3 \mathrm{Ma}$ (granite de Burnthill). Tous les plutons présentent des signatures géochimiques en
\end{abstract}


forme d'arc et intraplaques mixtes, bien que les granites du mont Redstone et de Burnthill soient surtout de type intraplaque.Les données sur les éléments traces des plutons de l'Ordovicien et du SilurienDévonien présentent une similitude géochimique globale étroite, ce qui indique qu'ils proviennent tous de la fusion partielle de sources crustales similaires et/ou partagent une pétrogenèse similaire. Les plutons du Silurien tardif au Dévonien précoce sont surtout des granites hyperalumineux à biotite et/ou muscovite et abritent potentiellement des minéralisations d'éléments granophiles. Tous les plutons contiennent des teneurs en Sn très supérieures à l'abondance moyenne générale des granites et plusieurs affichent des valeurs moyennes détain comparables à celles des granites stannifères productifs observés ailleurs. Les granites de Burnthill, du lac Lost, du mont Beadle et de Nashwaak sont les plus évolués sur le plan géochimique et les plus riches en Sn et en W. Le granite de Burnthill en particulier a connu des processus hydrothermaux de phase tardive qui ont abouti à des enrichissements locaux de ces éléments.

[Traduit par la redaction]

\section{INTRODUCTION}

The Central plutonic belt comprises mainly granitoid rocks that underlie a large area of central New Brunswick. They intruded Cambrian-Ordovician rocks of the Miramichi Group and Trousers Lake Metamorphic Suite in a $\sim 250 \mathrm{~km}$-long belt trending north-northeast that extends from the Maine border in southwestern New Brunswick to Chaleur Bay in the northeast (Fig. 1). Ranging in age from Early Ordovician to Late Devonian, these intrusive rocks are predominantly granites, and include several plutonic complexes of batholithic proportions, along with numerous smaller plutons (Fig. 1). The genetic association of some of these plutons with economic or potentially economic concentrations of elements such as Sn, W, Mo, $\mathrm{Cu}, \mathrm{Sb}, \mathrm{In}, \mathrm{Be}$, and $\mathrm{Au}$, has been known for many years (Ruitenberg and Fyffe 1982, and references therein).

A comprehensive study of granites from the Appalachian orogen in New Brunswick and the Gaspé Peninsula of Québec, including geological, petrographic, geochemical, isotopic and geochronological work, was carried out by the Geological Survey of Canada in the 1980s (Whalen 1993; Whalen et al. 1994, 1996, 1998). Almost all granitoid intrusive rocks in New Brunswick were sampled at that time, although difficulties involving access and exposure meant that some plutons, including most of the granites discussed herein, were only examined at a "reconnaissance" level. Geochronological work carried out during this and previous studies included $\mathrm{K}-\mathrm{Ar}$ and $\mathrm{Rb}-\mathrm{Sr}$ dating of the Redstone Mountain, Lost Lake, McKiel Lake, Bogan Brook and Nashwaak intrusions (Fyffe and Cormier 1979; Poole 1980; Bevier and Whalen 1990; Whalen and Theriault 1990), and ${ }^{40} \mathrm{Ar} /{ }^{39} \mathrm{Ar}$ dating of the Burnthill Granite (Taylor et al. 1987). More recently, attention was focused on New Brunswick granites and associated intrusion-related mineralization during the 2010-2015 federal-provincial Targeted Geoscience Initiative-4 (TGI-4) project (Rogers 2011), the purpose of which was to identify and evaluate "fertile" intrusions and vectors to additional W, Mo, Sn and other deposits. In the central part of the Central plutonic belt (Fig. 1), TGI-4 field work conducted by the New Brunswick Geological Surveys Branch centred on supplementing the

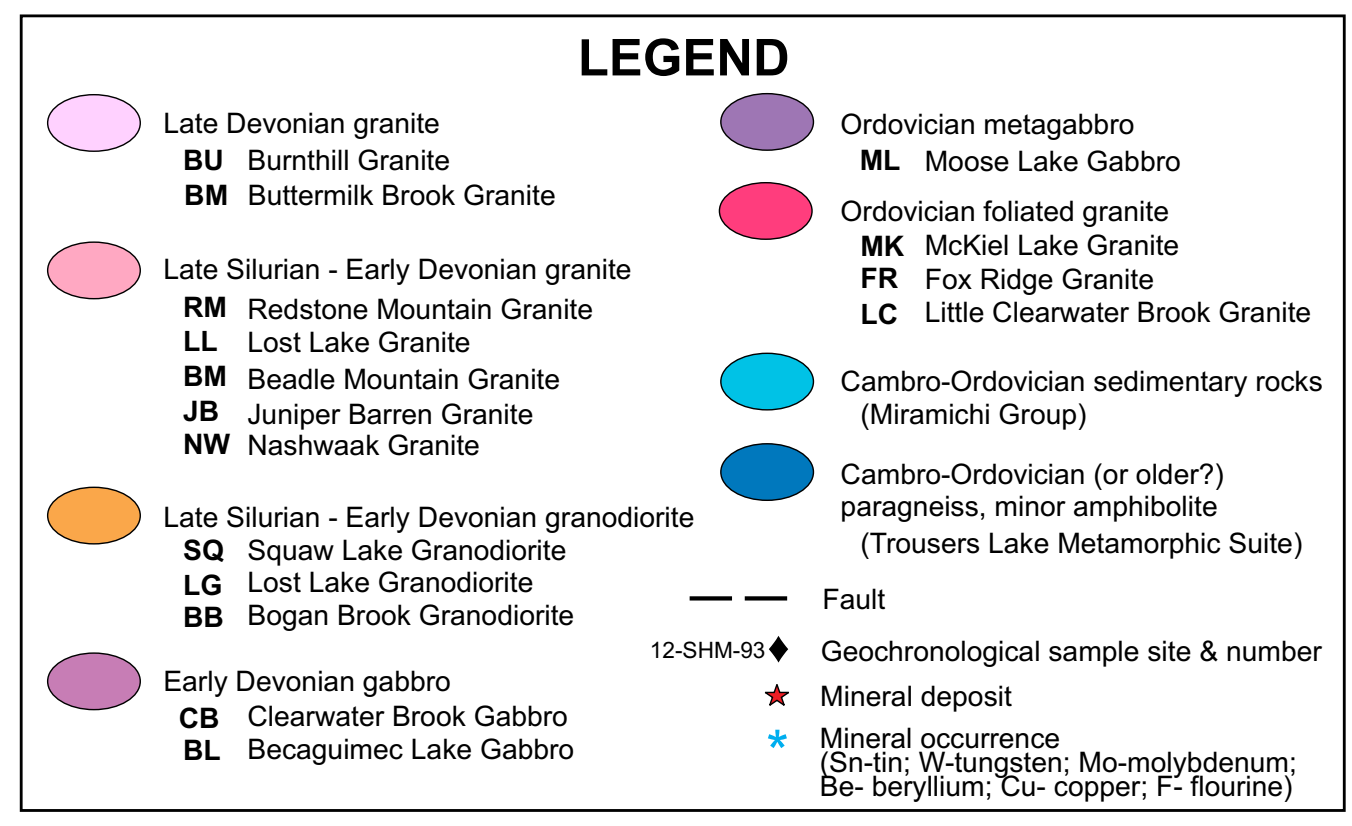

Geochronology and lithogeochemistry of granitoid rocks from Copyright (C) Atlantic Geology 2016 the central part of the Central plutonic belt, New Brunswick... 


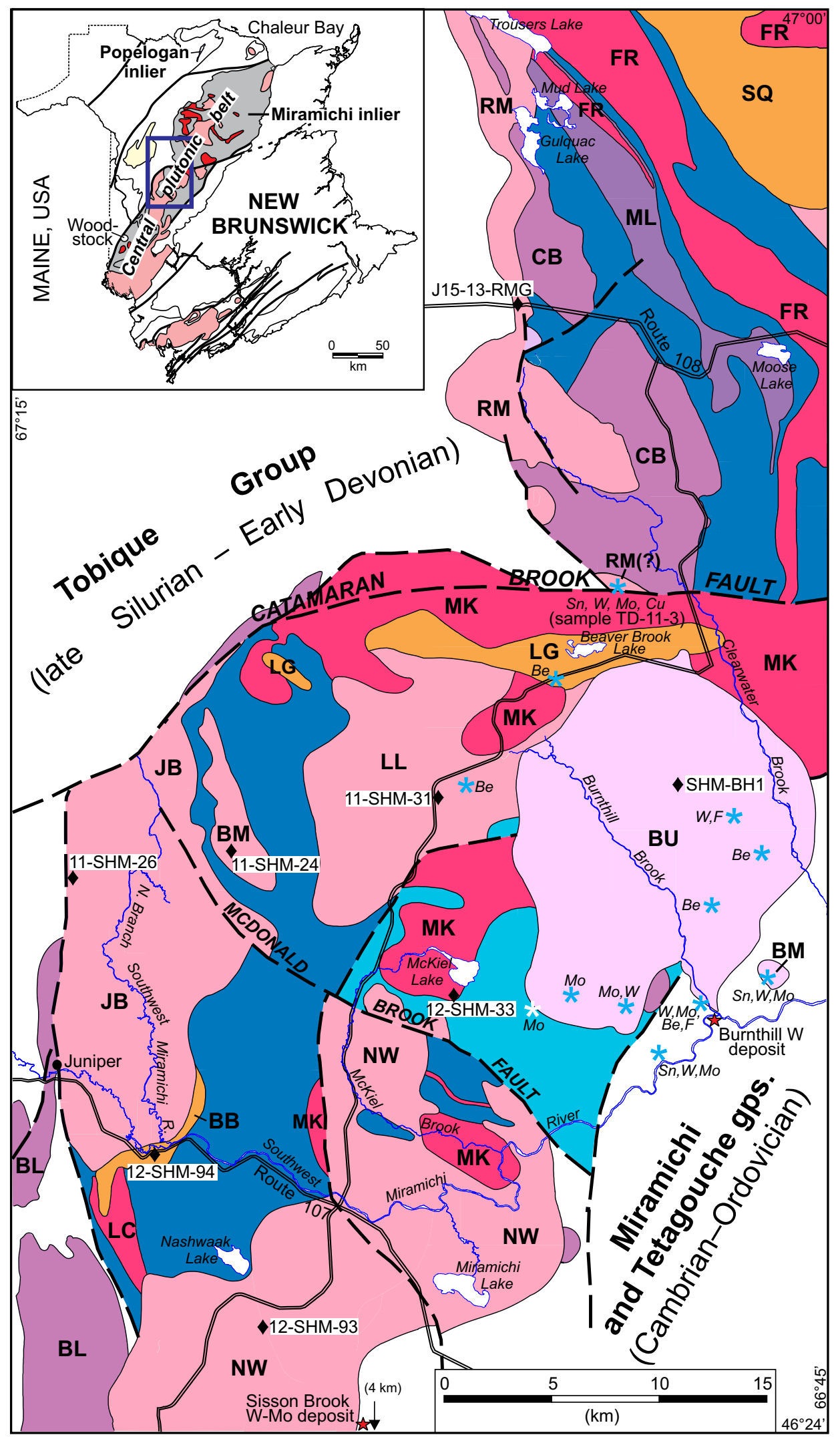

Figure 1. Geology of the central part of the Central plutonic belt, New Brunswick, modified after Smith and Fyffe (2006a). Legend is on the facing page. Inset: Ordovician granites are in red and Devonian granites in pink. 
Whalen (1993) database with the acquisition of additional lithogeochemical and geochronological analyses, and on producing improved geological maps for an area characterized by very poor bedrock exposure. This paper presents the results of new lithogeochemical analyses from ten plutons, and crystallization ages determined by Chemical Abrasion-Isotope Dilution-Thermal Ionization Mass Spectrometry (CA-ID-TIMS) for eight of those plutons. These data form the basis of inferences regarding the potential for economic concentrations of graniterelated mineralization in some of these intrusive rocks.

\section{OVERVIEW OF REGIONAL GEOLOGY}

The Central plutonic belt is situated almost entirely within the Miramichi inlier (Fig. 1), which comprises Cambrian to Ordovician stratified rocks of the Miramichi, Woodstock, and Meductic groups, the Bathurst Supergroup, and the Trousers Lake Metamorphic Suite. The Miramichi Group and correlative rocks of the Woodstock Group were deposited as a clastic apron on the passive margin of Ganderia following the late Neoproterozoic opening of the Iapetus Ocean and rifting of the Ganderian continental block from Amazonia (van Staal et al. 2009, 2012). The Trousers Lake Metamorphic Suite (Fyffe et al. 1988) underlies a 15-20 kmwide belt in the core of the Miramichi inlier; paragneiss that dominates this unit is generally interpreted as part of the Miramichi Group that was subjected to amphibolite-facies conditions, and juxtaposed against lower-grade Miramichi rocks along thrust or reverse fault(s) (Fyffe et al. 1988; McClenaghan et al. 2014). The Trousers Lake suite also includes minor amphibolite (metabasalt and metagabbro) and felsic orthogneiss that have been correlated with volcanic rocks of the Bathurst Supergroup (Fyffe et al. 1988; Winchester et al. 1992). The Bathurst Supergroup comprises volcanic and sedimentary rocks that were deposited during extension and rifting of the Early to Middle Ordovician, ensialic Popelogan arc, leading to opening of the Tetagouche backarc basin (van Staal et al. 2003, 2016). Early Ordovician, pre-rifting volcanic rocks of the Popelogan arc are exposed in the southwestern part of the Miramichi inlier near Woodstock, where they are assigned to the Meductic Group (Fyffe 2001), whereas Middle Ordovician, postrifting arc volcanic rocks are exposed in the Popelogan inlier in northern New Brunswick and assigned to the Balmoral Group (Wilson 2003) (Fig. 1 inset). All of these units were accreted to the Laurentian margin during the Salinic (Silurian) and Acadian (Devonian) orogenic cycles (van Staal and de Roo 1995; van Staal et al. 2003, 2009).

The oldest plutonic rocks in the Central plutonic belt are foliated granites that generally yield Floian to Darriwilian (Early to Middle Ordovician) U-Pb (zircon) ages (Whalen 1993; Whalen et al. 1998; McNicoll et al. 2003). For most of these intrusions, within-plate-like chemical signatures (Whalen 1993) strongly imply that they are plutonic equivalents of the backarc volcanic rocks of the Bathurst Supergroup. However, foliated granites with Early Ordovician ages predate backarc volcanism, suggesting correlation with arc volcanic rocks of the Meductic Group, although, except for the Gibson and Benton plutons in the Woodstock area (Whalen et al. 1998), these granites lack typical arc-like geochemical signatures. In the central part of the Central plutonic belt, the Fox Ridge Granite (Fig. 1; not sampled in this study) and felsic orthogneiss from the Trousers Lake Metamorphic Suite have yielded U-Pb (zircon) ages of 451 $+15 /-1 \mathrm{Ma}$ and $434+29 /-6 \mathrm{Ma}$, respectively (Fyffe et al. 1988); the older limits of these error ranges place both units in the Darriwilian, like most other Ordovician granites in the Miramichi inlier. In the study area, most foliated felsic intrusions are assigned to the McKiel Lake Granite, which, in addition to exposures in the type area at McKiel Lake, includes a large body on the south side of the Catamaran Brook Fault that was probably originally (prior to SilurianDevonian plutonism) contiguous with foliated granite in the upper part of Burnthill Brook (Fig. 1), and a smaller pluton on the lower part of McKiel Brook (Fig. 1) that Poole (1980) informally referred to as the "Sugar granite".

Most plutonic rocks in the study area are unfoliated granites. Based on previously acquired $\mathrm{Rb}-\mathrm{Sr}$ and $\mathrm{K}-\mathrm{Ar}$ ages (Fyffe and Cormier 1979; Poole 1980; Bevier and Whalen 1990; Whalen and Theriault 1990; see below), and U-Pb zircon and monazite ages from similar plutonic suites farther north (Bevier and Whalen 1990), these granites have been assumed to range in age from late Silurian to Early Devonian. Included in this group are the Lost Lake, Beadle Mountain, Juniper Barren, Nashwaak, and Redstone Mountain granites. Associated and generally smaller bodies of granodiorite (Lost Lake and Bogan Brook granodiorites) display a similar range of $\mathrm{K}-\mathrm{Ar}$ and $\mathrm{Rb}-\mathrm{Sr}$ ages but commonly have a weak foliation (Poole 1980; St. Peter 1981; Lutes 1981; Crouse 1981a). The Burnthill Granite clearly intruded the Lost Lake Granite, and supported by the results of previous ${ }^{40} \mathrm{Ar} /{ }^{39} \mathrm{Ar}$ dating (Taylor et al. 1987; see below), has historically been regarded as the youngest plutonic rock unit in the area.

\section{DESCRIPTION OF PLUTONS}

It is not the purpose of this contribution to present detailed lithological and petrographic descriptions of the plutonic rocks of central New Brunswick. This regional information can be obtained from previously published work by Whalen (1993), MacLellan et al. (1990), and several New Brunswick Geological Surveys reports from the late 1970s and early 1980s. For the interested reader, sources of lithological information for each of the ten plutons discussed herein have been tabulated (Table 1); brief lithological descriptions 
Table 1. Sources of lithological descriptions of granitoid rocks from the central part of the Central plutonic belt.

\begin{tabular}{|c|c|c|c|c|c|c|c|c|c|c|c|}
\hline & 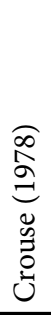 & 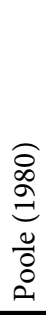 & 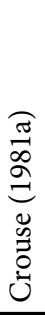 & 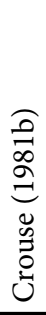 & 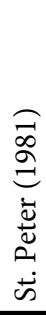 & 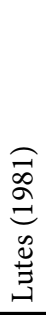 & 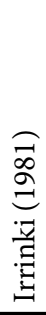 & 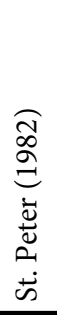 & 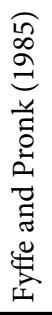 & 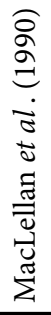 & 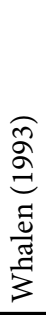 \\
\hline Burnthill Granite & & & $\mathrm{X}$ & & & & $\mathrm{X}$ & & & $\mathrm{X}$ & $\mathrm{X}$ \\
\hline Lost Lake Granite & & $\mathrm{X}$ & $\mathrm{X}$ & & $\mathrm{X}$ & & & & & & $\mathrm{X}$ \\
\hline Lost Lake Granodiorite & & & $\mathrm{X}$ & & $\mathrm{X}$ & & & & & & $\mathrm{X}$ \\
\hline Beadle Mountain Granite & & & & & $\mathrm{X}$ & & & & & & $\mathrm{X}$ \\
\hline Juniper Barren Granite & & & & & $\mathrm{X}$ & & & $\mathrm{X}$ & & & $\mathrm{X}$ \\
\hline Redstone Mountain Granite & $\mathrm{X}$ & & $\mathrm{X}$ & & & & & & $\mathrm{X}$ & & $\mathrm{X}$ \\
\hline Nashwaak Granite & & & $\mathrm{X}$ & $\mathrm{X}$ & $\mathrm{X}$ & $\mathrm{X}$ & & & & & $\mathrm{X}$ \\
\hline Bogan Brook Granodiorite & & & & & $\mathrm{X}$ & $\mathrm{X}$ & & & & & $\mathrm{X}$ \\
\hline Little Clearwater Brook Granite & & & & & $\mathrm{X}$ & $\mathrm{X}$ & & $\mathrm{X}$ & & & $\mathrm{X}$ \\
\hline McKiel Lake Granite* & & $\mathrm{X}$ & $\mathrm{X}$ & & $\mathrm{X}$ & & & & & & $\mathrm{X}$ \\
\hline
\end{tabular}

* Note: Whalen (1993) included the McKiel Lake Granite in his discussion of the Fox Ridge Granite.

are provided below. Many of these plutons, regardless of age, share characteristics such as the occurrence of pegmatite pods that locally contain tourmaline or beryl, garnetiferous aplitic dykes, and inclusions or enclaves of paragneiss ranging in size from small xenoliths to large roof pendants.

The Burnthill Granite is a texturally and mineralogically heterogeneous intrusion of coarse- to very coarse-grained biotite granite comprising a dominant phase of pink to red, medium- to coarse-grained, equigranular to seriate, alkali feldspar-phyric granite (Fig. 2a), and subsidiary phases of medium-grained equigranular granite, equigranular to quartz-feldspar-phyric microgranite, melanocratic biotite granite, and minor aplite and pegmatite (MacLellan et al. 1990). The Burnthill Granite intrudes Cambrian and Ordovician sedimentary and volcanic rocks of the Miramichi and Tetagouche groups, foliated granite (McKiel Lake Granite) and unfoliated granitoid rocks (Lost Lake Granite and Lost Lake Granodiorite). Tungsten mineralization at the Burnthill deposit (MacLellan et al. 1990) is genetically related to a buried cupola near the southeastern margin of the granite (Fig. 1).

The Lost Lake Granite comprises light grey to light pink, medium- to coarse-grained, equigranular, biotite \pm muscovite granite (Fig. 2b) and minor muscovite granite and pegmatite that commonly contain garnet, tourmaline, or beryl. It intrudes the foliated McKiel Lake Granite and high-grade metamorphic rocks (mainly paragneiss) of the Trousers Lake Metamorphic Suite, and is intruded by the Burnthill Granite.

The Lost Lake Granodiorite lies along the northern margin of the Lost Lake Granite (Fig. 1) and is interpreted as a cogenetic phase of the latter. It consists of grey to pink, fine- to medium-grained, equigranular biotite granite to granodiorite (Fig. 2c), and subordinate muscovite-biotite granite and muscovite pegmatite. It intrudes the McKiel Lake Granite and is intruded by the Burnthill Granite.

The Beadle Mountain Granite comprises light pink, medium- to coarse-grained, equigranular, muscovite, muscovite-biotite (Fig. 2d), and lesser biotite-muscovite granite, locally containing pods of muscovite-tourmaline pegmatite. The Beadle Mountain Granite has been interpreted to intrude the Juniper Barren Granite (St. Peter 1981), presumably as a younger, more evolved phase of that pluton, but for the most part it intrudes the Trousers Lake Metamorphic Suite near the eastern margin of the Juniper Barren Granite (Fig. 1).

The Juniper Barren Granite is composed of light grey to light pink, medium- to coarse-grained, equigranular to subporphyritic biotite granite (Fig. 3a), and minor biotite- and muscovite-bearing granite, garnetiferous aplite, and pegmatite. It intrudes the Trousers Lake Metamorphic Suite on the east and is in fault contact with Lower Devonian volcanic and sedimentary rocks of the Tobique Group on the north and west (Fig. 1).

The Redstone Mountain Granite comprises at least two phases, including pink to red, medium-grained, equigranular to subporphyritic biotite-amphibole granite containing sparse quartz phenocrysts and white plagioclase phenocrysts set in a fine-grained granophyric groundmass 
(Fig. 3b), and buff to maroon, probably subvolcanic quartzfeldspar porphyry. Associated with the granite are a local aplitic phase, porphyritic felsic dykes, and dykes and plugs of fine- to medium-grained, pyroxene-amphibole diabase and gabbro. The Redstone Mountain Granite intrudes the Trousers Lake Metamorphic Suite and the Clearwater Brook Gabbro on the east, and late Silurian to Early Devonian volcanic rocks of the Tobique Group (Costigan Mountain Formation) on the west (Fig. 1).

The Nashwaak Granite consists of light grey to light pink, medium- to coarse-grained, equigranular to seriate, biotite and biotite-muscovite granite (Fig. 3c) that locally contains xenoliths of paragneiss, and minor garnetiferous, muscovite-bearing granite. It intrudes the Trousers Lake Metamorphic Suite, Miramichi Group and McKiel Lake
Granite on the north, the Miramichi and Tetagouche groups and Howard Peak Granodiorite on the southeast, and the Becaguimec Lake Gabbro on the southwest (Fig. 1). The Sisson W-Mo deposit is located near the eastern margin of the Nashwaak Granite just south of the study area (Fig. 1).

The Bogan Brook Granodiorite is a medium to dark grey, fine- to medium-grained, equigranular biotite or hornblende-biotite granodiorite displaying a weak fabric and containing numerous xenoliths and enclaves of paragneiss or migmatized paragneiss (Fig. 3d) from the Trousers Lake Metamorphic Suite. It intrudes the latter unit and the Little Clearwater Brook Granite on the southeast, and is intruded by the Juniper Barren Granite on the northwest (Fig. 1).

The Little Clearwater Brook Granite consists of pink, medium-grained, foliated, porphyritic granite
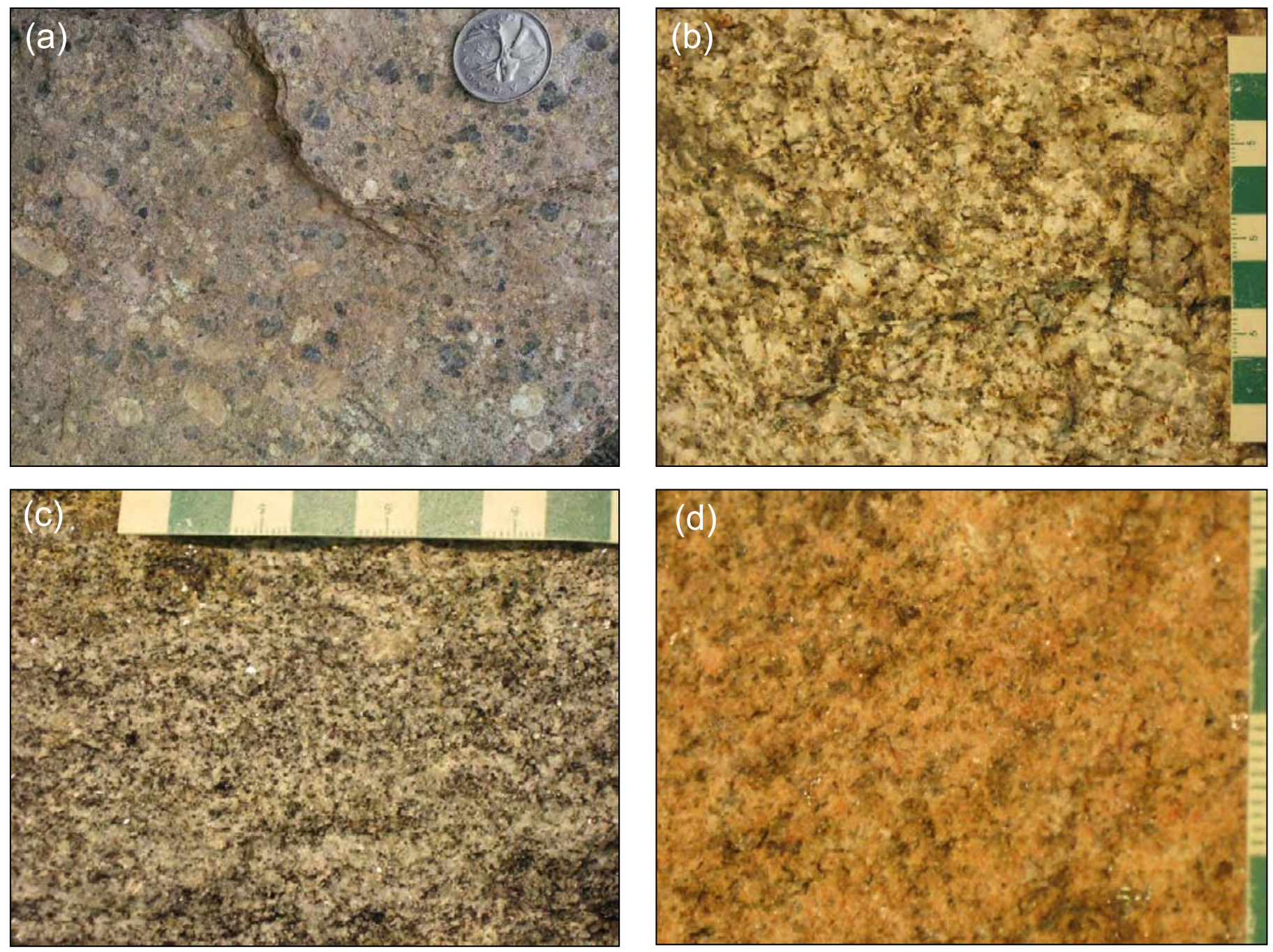

Figure 2. Photographs of plutonic rocks from the central part of the Central plutonic belt. (a) Burnthill Granite; (b) Lost Lake Granite; (c) Lost Lake Granodiorite; (d) Beadle Mountain Granite. Photographs (b), (c), and (d) by S.H. McClenaghan. 

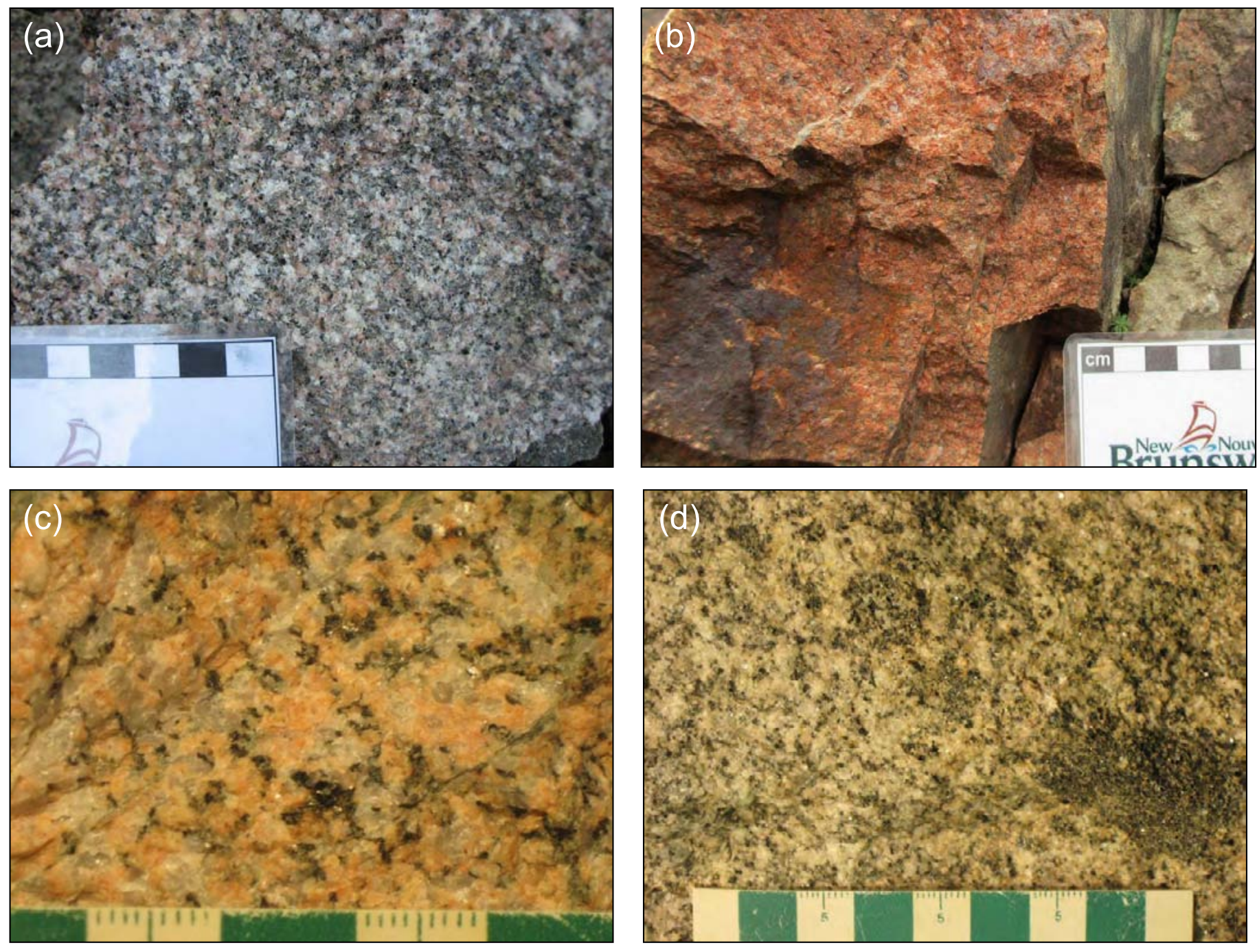

Figure 3. Photographs of plutonic rocks from the central part of the Central plutonic belt. (a) Juniper Barren Granite; (b) Redstone Mountain Granite; (c) Nashwaak Granite; (d) Bogan Brook Granodiorite (note partly assimilated xenolith of paragneiss in the lower right). Photographs (c) and (d) by S.H. McClenaghan.

containing alkali feldspar augen and local enclaves of Cambrian-Ordovician paragneiss (Fig. 4a). It intrudes the Trousers Lake Metamorphic Suite and is intruded by the Bogan Brook Granodiorite (Fig. 1).

The McKiel Lake Granite comprises grey to pink, medium- to coarse-grained, strongly foliated, equigranular to megacrystic (feldspar-augen) biotite granite (Fig. 4b), minor fine- to medium-grained, equigranular, biotitemuscovite granite and granite metaporphyry, and pods and veins/dykes of pegmatite. It intrudes the Trousers Lake Metamorphic Suite and Miramichi Group and is intruded by the Nashwaak, Burnthill, and Lost Lake plutons (Fig. 1).

\section{GEOCHRONOLOGY}

Granite samples from eight plutons were analysed at the Jack Satterly Geochronology Laboratory, University of Toronto. Analytical methods are given in Appendix A; geochronological data are presented in Table 2 and plotted on concordia diagrams in Figures $5 \mathrm{a}-\mathrm{h}$. Geologically young zircon grains generally have less accumulated radiogenic $\mathrm{Pb}$ than older grains, so in three cases multi-grain analyses were performed rather than single zircon grain analyses to ensure sufficient signal to noise ratios; however, this increases the likelihood of analyzing older, pre-emplacement (inherited) zircon. Due to the greater abundance of ${ }^{238} \mathrm{U}$ in geologically 

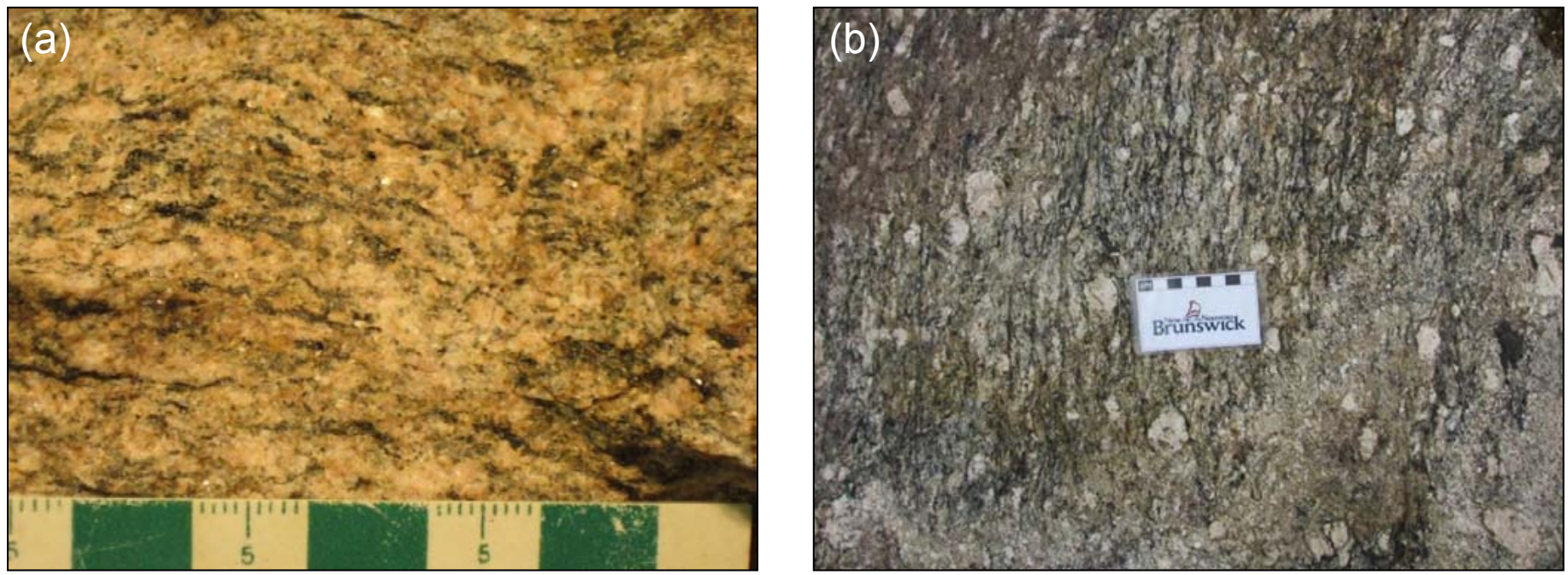

Figure 4. Photographs of plutonic rocks from the central part of the Central plutonic belt. (a) Little Clearwater Brook Granite; (b) McKiel Lake Granite. Photograph (a) is by S.H. McClenaghan.

young zircon, and the greater uncertainty in the accuracy of the ${ }^{235} \mathrm{U}$ decay constant (Schoene et al. 2006; Mattinson 2010), the average ${ }^{206} \mathrm{~Pb} /{ }^{238} \mathrm{U}$ age is considered the most reliable age interpretation in most of these samples. In this study, the best age estimates for the granites are based on the weighted average ${ }^{206} \mathrm{~Pb} /{ }^{238} \mathrm{U}$ dates, with the exception of the last three reported samples. In the latter cases (12-SHM-93, -94, -33), it is interpreted that $\mathrm{Pb}$ loss has resulted in discordance in some analyses, in which case both the oldest single ${ }^{206} \mathrm{~Pb} /{ }^{238} \mathrm{U}$ date and the weighted average ${ }^{207} \mathrm{~Pb} /{ }^{206} \mathrm{~Pb}$ age are given as minimum and maximum age estimates, respectively.

11-SHM-BH1: Burnthill Granite. Long, prismatic, euhedral crystals generally devoid of inclusions and cracks were analyzed. Two single grains and one fraction of two prismatic euhedral fragments (Z1-Z3) gave overlapping, concordant data with a weighted mean ${ }^{206} \mathrm{~Pb} /{ }^{238} \mathrm{U}$ age of $380.6 \pm 0.3 \mathrm{Ma}$ (MSWD $=1.3$; Fig. 5a), which is interpreted as the best estimate for the time of granite emplacement and crystallization.

11-SHM-31: Lost Lake Granite. Three of four single zircon grains (Z2-Z4) selected from an abundant population of clear, gem quality grains gave equivalent ${ }^{206} \mathrm{~Pb} /{ }^{238} \mathrm{U}$ ages with a weighted mean of $409.7 \pm 0.5 \mathrm{Ma}$ (MSWD = 0.9; Fig. 5b). This age is interpreted as the time of granite emplacement and crystallization. A fourth grain (Z1) is slightly older at $413.8 \pm 0.9 \mathrm{Ma}$ and is interpreted as xenocrystic, or it may contain an inherited core component, and was therefore excluded from the mean.

11-SHM-24: Beadle Mountain Granite. Elongate to equant, euhedral zircon crystals were selected for chemical abrasion. Two single grains (Z2 and Z3) gave concordant and overlapping data that have a weighted mean ${ }^{206} \mathrm{~Pb} /{ }^{238} \mathrm{U}$ age of $416.1 \pm 0.5 \mathrm{Ma}$ (MSWD = 1.3; Fig. 5c). Five small crystals (Z1) gave concordant data with an older ${ }^{206} \mathrm{~Pb} /{ }^{238} \mathrm{U}$ age of
$433.0 \pm 0.7 \mathrm{Ma}$, which was likely a mixture of magmatic grains and one or more inherited grains, and is therefore not considered geologically meaningful. The $416.1 \pm 0.5 \mathrm{Ma}$ age is considered the best age estimate for granite crystallization.

11-SHM-26: Juniper Barren Granite. Abundant, euhedral, elongate to equant zircon grains are largely unaltered, and a group of the clearest grains was selected for chemical abrasion. Three single zircon grains $(\mathrm{Z} 1-\mathrm{Z} 3)$ gave concordant, overlapping data that have a weighted mean ${ }^{206} \mathrm{~Pb} /{ }^{238} \mathrm{U}$ age of $415.8 \pm 0.3 \mathrm{Ma}(\mathrm{MSWD}=1.7$; Fig. $5 \mathrm{~d})$. This is interpreted as the best estimate for the time of emplacement and crystallization of the granite, and is within error of the $416.1 \pm 0.5 \mathrm{Ma}$ age for the Beadle Mountain Granite.

J15-13-RMG: Redstone Mountain Granite. Zircon crystals from this granite are typically fresh, euhedral stubby prisms. Three analyses (one single grain and two analyses of two grains each) gave concordant, overlapping data with a weighted mean ${ }^{206} \mathrm{~Pb} /{ }^{238} \mathrm{U}$ age of $419.0 \pm 0.5 \mathrm{Ma}$ (MSWD $=1.6$; Fig. $5 \mathrm{e}$ ), and this age is interpreted to best estimate the time of granite crystallization. One grain (Z1), larger and older than the other dated grains, is interpreted as a xenocryst and has a ${ }^{206} \mathrm{~Pb} /{ }^{238} \mathrm{U}$ age of $423.3 \pm 0.6 \mathrm{Ma}$.

12-SHM-93: Nashwaak Granite. Three elongate, euhedral zircon crystals selected for chemical abrasion gave overlapping data $(\mathrm{Z} 1-\mathrm{Z} 3)$ that are $0.9 \%$ to $2.7 \%$ discordant and have consistent ${ }^{207} \mathrm{~Pb} /{ }^{206} \mathrm{~Pb}$ ages. A line through all of the data indicates intercept ages of $423 \pm 16 \mathrm{Ma}$ and 134 $\pm 640 \mathrm{Ma}(\mathrm{MSWD}=0.21$ ) when unconstrained, but is imprecise due to the lack of spread in the data. If timeaveraged $\mathrm{Pb}$ loss at $200 \mathrm{Ma}$ is assumed, an upper intercept age of $425.1 \pm 3.5 \mathrm{Ma}(\mathrm{MSWD}=0.15)$ is given. The youngest possible age interpretation is given by the oldest ${ }^{206} \mathrm{~Pb} /{ }^{238} \mathrm{U}$ age for $\mathrm{Z} 1$ at $417.2 \pm 0.7 \mathrm{Ma}$, but if any $\mathrm{Pb}$ loss 
Table 2. U-Pb CA-ID-TIMS zircon data for granite samples from the central part of thr Central plutonic belt, New Brunswick.

\begin{tabular}{|c|c|c|c|c|c|c|c|c|c|c|c|c|c|c|c|c|c|}
\hline \multirow{2}{*}{\multicolumn{2}{|c|}{$\begin{array}{c}\text { Sample/ } \\
\text { Analysis no. }\end{array}$}} & \multirow[b]{2}{*}{$\begin{array}{c}\text { Weight } \\
(\mu \mathrm{g})\end{array}$} & \multirow[b]{2}{*}{$\begin{array}{c}\mathrm{U} \\
(\mathrm{ppm}\end{array}$} & \multicolumn{8}{|c|}{ Isotopic ratios } & \multicolumn{6}{|c|}{ Apparent age (Ma) } \\
\hline & & & & $\begin{array}{c}\mathrm{Th} / \\
\mathrm{U}\end{array}$ & $\begin{array}{l}\mathrm{PbC} \\
(\mathrm{pg}) \\
\end{array}$ & $\begin{array}{l}{ }^{206} \mathrm{~Pb} / \\
{ }^{204} \mathrm{~Pb}\end{array}$ & $\begin{array}{l}{ }^{207} \mathrm{~Pb} / \\
{ }^{235} \mathrm{U} \\
\end{array}$ & $2 \sigma$ & $\begin{array}{l}{ }^{206} \mathrm{~Pb} / \\
{ }^{238} \mathrm{U} \\
\end{array}$ & $2 \sigma$ & $\rho$ & ${ }^{{ }^{206} \mathrm{~Pb} /}$ & $2 \sigma$ & $\begin{array}{l}{ }^{207} \mathrm{~Pb} / \\
{ }^{235} \mathrm{U} \\
\end{array}$ & $2 \sigma$ & $\begin{array}{l}{ }^{207} \mathrm{~Pb} / \\
{ }^{206} \mathrm{~Pb}\end{array}$ & $2 \sigma$ \\
\hline \multicolumn{18}{|c|}{ A 11-SHM-BH1, Burnthill Granite (Lat. 46-40-18.0N; Long. 66-50-12.0W) } \\
\hline & $\mathrm{Z} 1$ & 3.1 & 247 & 0.50 & 0.6 & 5136 & 0.4545 & 0.0016 & 0.06084 & 0.00007 & 0.607 & 380.75 & 0.44 & 380.5 & 1.1 & 379 & 7 \\
\hline & $\mathrm{Z}^{*}$ & 3.8 & 250 & 0.53 & 0.6 & 6476 & 0.4540 & 0.0015 & 0.06081 & 0.00011 & 0.702 & 380.56 & 0.65 & 380.1 & 1.0 & 377 & 5 \\
\hline & $\mathrm{Z3}$ & 5.5 & 141 & 0.46 & 0.7 & 4268 & 0.4542 & 0.0017 & 0.06075 & 0.00010 & 0.614 & 380.16 & 0.59 & 380.2 & 1.2 & 381 & 7 \\
\hline \multicolumn{18}{|c|}{ B 11-SHM-031, Lost Lake Granite (Lat. 46-40-08.2N; Long. 66-59-40.0W) } \\
\hline & $\mathrm{Z} 1$ & 2.8 & 172 & 0.49 & 0.5 & 3906 & 0.5004 & 0.0021 & 0.06630 & 0.00015 & 0.661 & 413.80 & 0.90 & 412.0 & 1.4 & 402 & 7 \\
\hline & $\mathrm{Z} 2$ & 1.5 & 176 & 0.43 & 2.9 & 399 & 0.4896 & 0.0209 & 0.06572 & 0.00040 & 0.532 & 410.32 & 2.42 & 404.6 & 14.2 & 372 & 89 \\
\hline & $\mathrm{Z3}$ & 3.0 & 129 & 0.35 & 1.8 & 901 & 0.4883 & 0.0071 & 0.06568 & 0.00012 & 0.604 & 410.06 & 0.74 & 403.7 & 4.8 & 368 & 30 \\
\hline & $\mathrm{Z} 4$ & 1.6 & 123 & 0.39 & 1.0 & 807 & 0.4812 & 0.0073 & 0.06558 & 0.00011 & 0.667 & 409.44 & 0.65 & 398.9 & 5.0 & 338 & 32 \\
\hline \multicolumn{18}{|c|}{ C 11-SHM-024, Beadle Mountain Granite (Lat. 46-38-34.2N; Long. 67-07-10.9W) } \\
\hline & $\mathrm{Z} 1^{* *}$ & 2.6 & 319 & 0.32 & 0.2 & 15996 & 0.5325 & 0.0014 & 0.06948 & 0.00012 & 0.805 & 433.00 & 0.74 & 433.5 & 0.9 & 436 & 4 \\
\hline & $\mathrm{Z} 2$ & 3.1 & 218 & 0.48 & 0.5 & 6302 & 0.5077 & 0.0018 & 0.06673 & 0.00013 & 0.686 & 416.45 & 0.76 & 416.9 & 1.2 & 419 & 6 \\
\hline & $\mathrm{Z3}$ & 2.6 & 187 & 0.42 & 0.3 & 7748 & 0.5068 & 0.0015 & 0.06663 & 0.00012 & 0.763 & 415.84 & 0.72 & 416.3 & 1.0 & 419 & 4 \\
\hline \multicolumn{18}{|c|}{ D 11-SHM-026, Juniper Barren Granite (Lat. 46-37-56.4N; Long. 67-12-53.1W) } \\
\hline & $\mathrm{Z} 1$ & 2.2 & 228 & 0.41 & 0.5 & 4535 & 0.5059 & 0.0017 & 0.06668 & 0.00008 & 0.629 & 416.11 & 0.51 & 415.7 & 1.2 & 413 & 6 \\
\hline & $\mathrm{Z} 2$ & 1.5 & 201 & 0.44 & 0.2 & 5856 & 0.5079 & 0.0027 & 0.06664 & 0.00008 & 0.469 & 415.90 & 0.50 & 417.0 & 1.8 & 423 & 11 \\
\hline & $\mathrm{Z3}$ & 2.1 & 144 & 0.46 & 0.4 & 3537 & 0.5061 & 0.0020 & 0.06657 & 0.00008 & 0.603 & 415.48 & 0.49 & 415.8 & 1.4 & 418 & 8 \\
\hline \multicolumn{18}{|c|}{ E J15-13-RMG, Redstone Mountain Granite (Lat. 46-52-31.2N, Long. 66-56-46.6W) } \\
\hline & $\mathrm{Z} 1$ & 13.0 & 75 & 0.51 & 1.6 & 2536 & 0.5165 & 0.0026 & 0.06787 & 0.00010 & 0.564 & 423.31 & 0.63 & 422.8 & 1.7 & 420 & 10 \\
\hline & $\mathrm{Z} 2$ & 4.0 & 230 & 0.59 & 0.8 & 4810 & 0.5120 & 0.0017 & 0.06723 & 0.00012 & 0.674 & 419.46 & 0.70 & 419.8 & 1.1 & 422 & 6 \\
\hline & $\mathrm{Z3}^{*}$ & 5.0 & 131 & 0.50 & 0.6 & 4988 & 0.5121 & 0.0023 & 0.06712 & 0.00023 & 0.814 & 418.79 & 1.36 & 419.8 & 1.6 & 426 & 6 \\
\hline & $\mathrm{Z}^{*}$ & 1.0 & 503 & 0.68 & 0.4 & 5883 & 0.5113 & 0.0020 & 0.06707 & 0.00015 & 0.675 & 418.46 & 0.88 & 419.3 & 1.3 & 424 & 6 \\
\hline \multicolumn{18}{|c|}{ F 12-SHM-93, Nashwaak Granite (Lat. 46-26-41.0N, Long. 67-06-04.3W) } \\
\hline & $\mathrm{Z} 1$ & 3.7 & 171 & 0.34 & 0.5 & 5432 & 0.5090 & 0.0017 & 0.06685 & 0.00012 & 0.707 & 417.16 & 0.73 & 417.8 & 1.1 & 421 & 5 \\
\hline & $\mathrm{Z} 2$ & 2.8 & 215 & 0.39 & 0.2 & 11189 & 0.5079 & 0.0035 & 0.06671 & 0.00044 & 0.981 & 416.30 & 2.68 & 417.0 & 2.4 & 421 & 3 \\
\hline & $\mathrm{Z3}$ & 0.8 & 681 & 0.36 & 0.2 & 15285 & 0.5049 & 0.0010 & 0.06635 & 0.00007 & 0.828 & 414.10 & 0.39 & 415.0 & 0.7 & 420 & 3 \\
\hline \multicolumn{18}{|c|}{ G 12-SHM-94, Bogan Brook Granodiorite (Lat. 46-30-59.9N, Long. 67-09-49.9W) } \\
\hline & $\mathrm{Z} 1$ & 3.0 & 205 & 0.28 & 0.3 & 8151 & 0.5530 & 0.0044 & 0.07132 & 0.00048 & 0.854 & 444.11 & 2.89 & 447.0 & 2.9 & 462 & 9 \\
\hline & $\mathrm{Z} 2$ & 2.8 & 174 & 0.44 & 0.3 & 7786 & 0.5092 & 0.0024 & 0.06679 & 0.00011 & 0.539 & 416.80 & 0.68 & 417.9 & 1.6 & 424 & 9 \\
\hline & $\mathrm{Z3}$ & 5.4 & 177 & 0.53 & 0.4 & 9333 & 0.5060 & 0.0056 & 0.06637 & 0.00072 & 0.986 & 414.25 & 4.36 & 415.8 & 3.8 & 424 & 4 \\
\hline & $\mathrm{Z} 4$ & 3.2 & 247 & 0.65 & 0.4 & 9199 & 0.5052 & 0.0019 & 0.06635 & 0.00019 & 0.747 & 414.12 & 1.12 & 415.2 & 1.3 & 421 & 6 \\
\hline \multicolumn{18}{|c|}{ H 12-SHM-33, McKiel Lake Granite (Lat. 46-34-55.9N, Long. 66-58-54.3W) } \\
\hline & $\mathrm{Z} 1$ & 1.4 & 170 & 0.39 & 0.3 & 3715 & 0.6197 & 0.0036 & 0.07542 & 0.00013 & 0.545 & 468.71 & 0.81 & 489.7 & 2.2 & 589 & 11 \\
\hline & $\mathrm{Z} 2$ & 1.3 & 158 & 0.49 & 0.6 & 1776 & 0.5764 & 0.0049 & 0.07414 & 0.00014 & 0.528 & 461.05 & 0.82 & 462.1 & 3.1 & 468 & 17 \\
\hline & $\mathrm{Z3}$ & 1.2 & 260 & 0.42 & 1.0 & 1429 & 0.5692 & 0.0047 & 0.07296 & 0.00014 & 0.523 & 453.98 & 0.84 & 457.5 & 3.1 & 475 & 17 \\
\hline & $\mathrm{Z} 4$ & 1.3 & 318 & na & 0.7 & 2599 & 0.5659 & 0.0028 & 0.07293 & 0.00007 & 0.620 & 453.77 & 0.42 & 455.4 & 1.8 & 463 & 10 \\
\hline
\end{tabular}

Notes: Chemically abraded single zircon crystals were analyzed (Mattinson 2005) except for 2 analyses that had 2 grains each $\left({ }^{*}\right)$ and one analysis with 5 grains $\left(^{* *}\right)$.

A mixed ${ }^{205} \mathrm{~Pb}-{ }^{233-235} \mathrm{U}$ spike (ET535) was used in all but $11-\mathrm{SHM}-24$ which used the $\mathrm{ROM}{ }^{205} \mathrm{~Pb}^{-235} \mathrm{U}$ spike.

$\mathrm{Th} / \mathrm{U}$ calculated from radiogenic ${ }^{208} \mathrm{~Pb} /{ }^{206} \mathrm{~Pb}$ ratio and ${ }^{207} \mathrm{~Pb} /{ }^{206} \mathrm{~Pb}$ age assuming concordance.

$\mathrm{PbC}$ is total common $\mathrm{Pb}$ assuming isotopic composition of laboratory blank.

${ }^{206} \mathrm{~Pb} /{ }^{204} \mathrm{~Pb}$ measured and corrected for fractionation and common $\mathrm{Pb}$ in the spike.

$\mathrm{Pb} / \mathrm{U}$ ratios corrected for fractionation, common $\mathrm{Pb}$ in the spike, and blank; no correction for initial common $\mathrm{Pb}$ from geological sources was made.

Correction for ${ }^{230} \mathrm{Th}$ disequilibrium in ${ }^{206} \mathrm{~Pb} /{ }^{238} \mathrm{U}$ and ${ }^{207} \mathrm{~Pb} /{ }^{206} \mathrm{~Pb}$ assuming $\mathrm{Th} / \mathrm{U}$ of 4.2 in the magma.

$\rho=$ correlation coefficients of $\mathrm{X}-\mathrm{Y}$ errors on the concordia plot. 

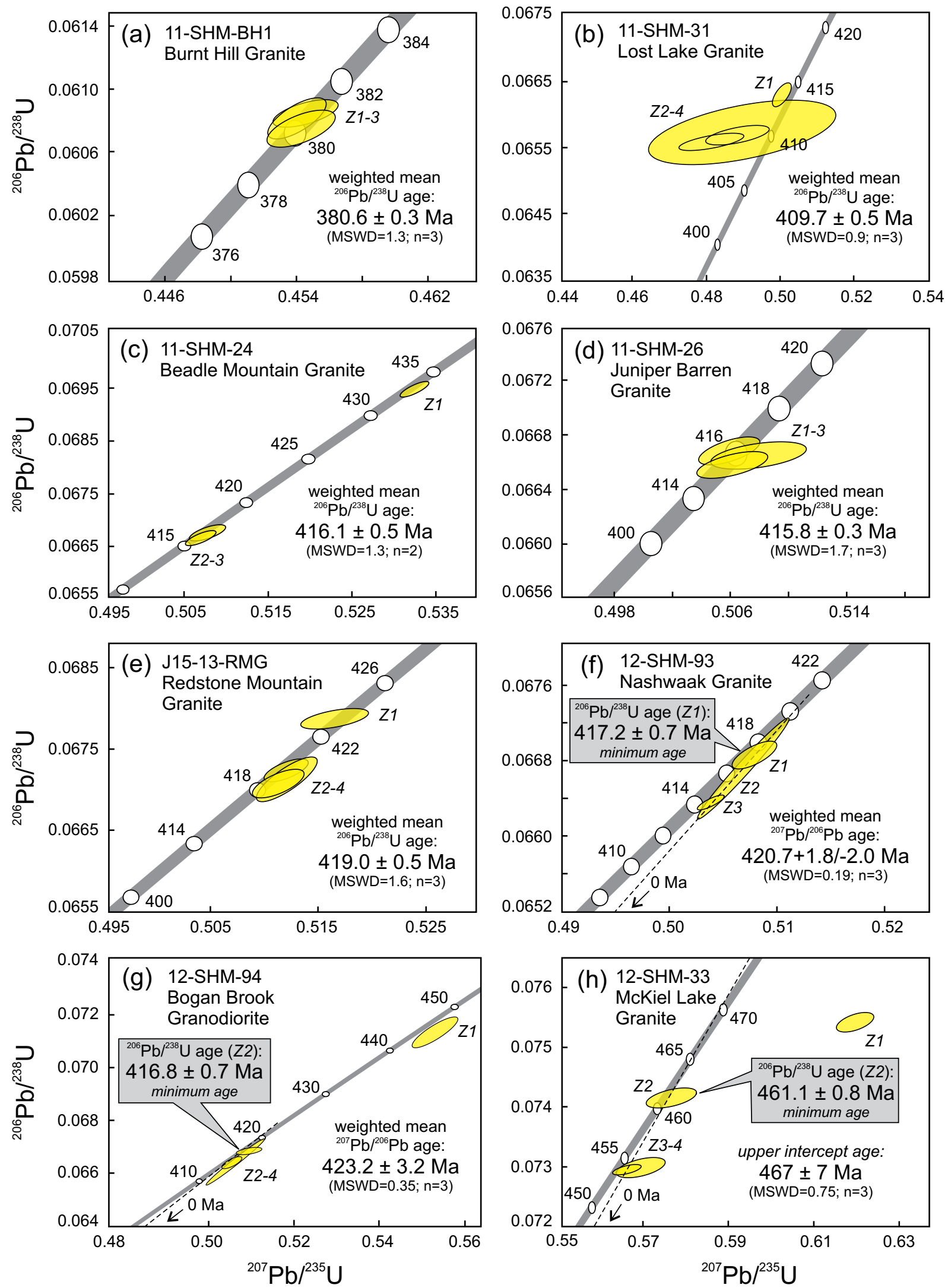

Figure 5. $\mathrm{U}-\mathrm{Pb}$ concordia diagrams showing data for single, chemically abraded zircon grains from granites of the central part of the Central plutonic belt, New Brunswick. See Figure 1 for locations. 
has occurred this age would be too young. A line calculation anchored at $0 \mathrm{Ma}$ (which is the same as taking the mean ${ }^{207} \mathrm{~Pb} /{ }^{206} \mathrm{~Pb}$ age) gives an upper intercept age of $420.7+1.8 /$ $2.0 \mathrm{Ma}$ (MSWD = 0.19; Fig. 5f), which takes into account all of the data and incorporates the possibility of recent minor $\mathrm{Pb}$ loss, and is interpreted to represent a minimum age that approximates the time of granite emplacement.

12-SHM-94: Bogan Brook Granodiorite. Three single stubby to elongate euhedral prismatic zircon crystals (Z2Z4) give overlapping discordant data (1.7-2.7\%) that have an upper intercept age of $423.2 \pm 3.2 \mathrm{Ma}$ when constrained through $0 \mathrm{Ma}$ (i.e., the mean ${ }^{207} \mathrm{~Pb} /{ }^{206} \mathrm{~Pb}$ age) (Fig. $5 \mathrm{~g}$ ). The slight discordance of the data leaves the age interpretation open to the possibility of early $\mathrm{Pb}$ loss. A line anchored at $200 \mathrm{Ma}$, for example, increases the upper intercept age to $430 \pm 6 \mathrm{Ma}(\mathrm{MSWD}=0.29)$, which is within error of the mean ${ }^{207} \mathrm{~Pb} /{ }^{206} \mathrm{~Pb}$ age. The $423.2 \pm 3.2 \mathrm{Ma}$ age is interpreted as a close estimate for the time of granite emplacement, but should be considered a minimum age estimate. A fourth grain (Z1) is older and discordant (462 $\pm 9 \mathrm{Ma}, 3.9 \%$ discordant) and apparently inherited from an older crustal source.

12-SHM-33: McKiel Lake Granite. U-Pb data for three single, euhedral, stubby to elongate, prismatic zircon crystals, can be interpreted to indicate a maximum age of $467 \pm 7 \mathrm{Ma}$ (Fig. $5 \mathrm{~h}$ ), based on a Pb loss line anchored at 0 $\mathrm{Ma}$ and using concordant datum $\mathrm{Z} 2$, which has a ${ }^{207} \mathrm{~Pb} /{ }^{206} \mathrm{~Pb}$ age of $468 \pm 17 \mathrm{Ma}$ (1.4\% discordant), and two younger, overlapping and discordant data $(\mathrm{Z} 3-\mathrm{Z} 4)$ that plot just to the right of the curve. The $467 \pm 7 \mathrm{Ma}$ age is considered the best approximation for the time of granite crystallization, implying emplacement in the Middle Ordovician, although an Early Ordovician age cannot be ruled out.

\section{Discussion of geochronological data}

$\mathrm{U}-\mathrm{Pb}$ (zircon) age determinations confirm that granites from the central part of the Central plutonic belt were emplaced at three widely spaced time intervals, namely Early to Middle Ordovician ( $467 \pm 7 \mathrm{Ma}$ ) for foliated granite, late Silurian to Early Devonian (423 to $409 \mathrm{Ma}$ ) for most of the unfoliated granites, and Late Devonian (380 Ma) for the post-orogenic Burnthill Granite. The McKiel Lake Granite is similar in age to other Ordovician granites in the Miramichi inlier/Central plutonic belt (McNicoll et al. 2003). Aside from the Bogan Brook Granodiorite, the Nashwaak Granite is the oldest Silurian-Devonian pluton yet dated in the belt; however, if no $\mathrm{Pb}$ loss has occurred, the age may be similar to that of the Juniper Barren Granite a few $\mathrm{km}$ to the northwest (Fig. 1). Furthermore, the granite has been shown to consist of more than one phase (Lutes 1981), so it is possible that undated parts of the granites may be younger. The ages of the Juniper Barren and Beadle Mountain granites overlap within error, and are very close to the ages of large batholiths north of the study area, namely the North Pole
Stream Granite (417 $\pm 1 \mathrm{Ma})$ and Mount Elizabeth Granite $(417 \pm 2 \mathrm{Ma})$ (Bevier and Whalen 1990). In view of their close proximity and several geochemical indicators (see below), it seems clear that the Beadle Mountain Granite is a more evolved phase of the Juniper Barren Granite. St. Peter (1981) reported veins of muscovite granite cutting the Juniper Barren Granite; hence, despite the interpreted crystallization age suggesting that it is slightly older, the Beadle Mountain Granite is probably slightly younger. The Redstone Mountain Granite is intermediate in age between the Nashwaak and Juniper Barren/Beadle Mountain intrusions, but is geochemically distinct and interpreted to be tectonomagmatically unrelated to the other SilurianDevonian granites, as discussed below. The Lost Lake Granite is the youngest of the Early Devonian plutonic family, and a hiatus of almost 30 myr separates it from the highly evolved and metal-specialized Burnthill Granite.

Newly acquired U-Pb (zircon) data have been compiled in chart form along with previously published $\mathrm{Rb}-\mathrm{Sr}, \mathrm{K}-\mathrm{Ar}$ or ${ }^{40} \mathrm{Ar} /{ }^{39} \mathrm{Ar}$ mineral or whole-rock ages to facilitate easy comparisons (Fig. 6). It is immediately clear from the chart that several of the U-Pb (zircon) crystallization ages are very close to the mineral ages. For example, five ${ }^{40} \mathrm{Ar} /{ }^{39} \mathrm{Ar}$ (biotite and muscovite) plateau and total gas ages reported for the Burnthill Granite range from 377 to $386 \mathrm{Ma}$ (Taylor et al. 1987), including three ages (380 Ma-biotite total gas, $378 \pm 3$ Ma-biotite plateau; and $379 \pm 4 \mathrm{Ma}$-muscovite total gas) that closely match the U-Pb emplacement age of $380.6 \pm 0.3 \mathrm{Ma}$, as well as the inferred crystallization age of 381 Ma proposed by MacLellan et al. (1990). Similarly, $\mathrm{Rb}-\mathrm{Sr}$ whole-rock isochron ages of $412 \pm 12 \mathrm{Ma}$ and 411 $\pm 13 \mathrm{Ma}$ (Poole 1980), and K-Ar (muscovite) and K-Ar (biotite) ages of $408 \pm 7 \mathrm{Ma}$ and $402 \pm 4 \mathrm{Ma}$, respectively (Whalen and Theriault 1990) compare well with the $409.7 \pm$ $0.5 \mathrm{Ma}$ crystallization age of the Lost Lake Granite. Slightly younger K-Ar muscovite and biotite ages of $402 \pm 5 \mathrm{Ma}$ and $398 \pm 4 \mathrm{Ma}$, respectively, were reported for the Lost Lake Granodiorite. The 420.7+1.8/-2.0 Ma TIMS age of the Nashwaak Granite overlaps the Rb-Sr (muscovite) age of $422 \pm 4$ Ma reported by Whalen and Theriault (1990), although their K-Ar (muscovite) age of $396 \pm 5 \mathrm{Ma}$ from the same location is difficult to explain. The Bogan Brook Granodiorite has yielded a K-Ar (muscovite) age of $421 \pm 6$ $\mathrm{Ma}$ (Bevier and Whalen 1990), overlapping the TIMS age of $423.2 \pm 3.2 \mathrm{Ma}$. The reported $\mathrm{Rb}-\mathrm{Sr}$ (muscovite) age of 433 $\pm 4 \mathrm{Ma}$ (Bevier and Whalen 1990) was interpreted as being closer to the age of emplacement, and the younger $\mathrm{K}-\mathrm{Ar}$ (muscovite) age to reflect a long cooling history, but the older age clearly requires a different explanation, probably involving lack of closure of the system with respect to $\mathrm{Rb}$ and Sr. (It should be noted that Whalen and Theriault (1990) and Bevier and Whalen (1990) incorrectly identify the sampled pluton as Juniper Barren Granite, which is adjacent to the Bogan Brook Granodiorite). Finally, Poole (1980) reported 


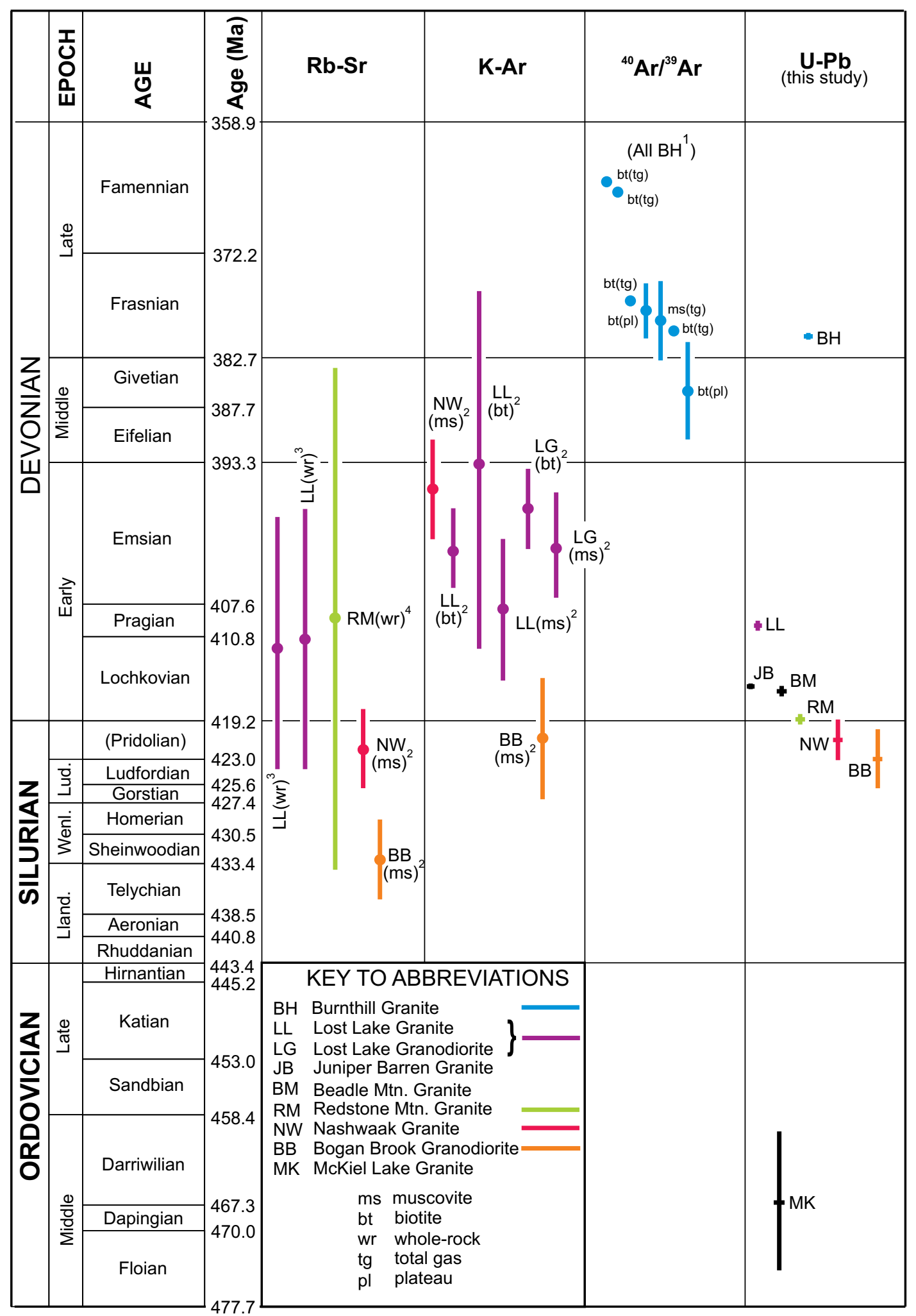

Figure 6. Compilation of radioisotopic data for granitoid rocks from the study area, comparing $\mathrm{U}-\mathrm{Pb}$ (zircon) crystallization ages with previously acquired $\mathrm{Rb}-\mathrm{Sr}, \mathrm{K}-\mathrm{Ar}$ and ${ }^{40} \mathrm{Ar} /{ }^{39} \mathrm{Ar}$ mineral ages. See text for discussion. Numerical superscripts refer to sources of data: 1 - Taylor et al. (1987); 2 - Whalen and Theriault (1990); 3 - Poole (1980); 4- Fyffe and Cormier (1979). 
a Rb-Sr whole-rock isochron of $498 \pm 19 \mathrm{Ma}$ for five of eight whole rock samples, and an errorchron of $484 \pm 33 \mathrm{Ma}$ for eight samples of his "Sugar granite". Again, mineral ages exceeding the $467 \pm 7$ Ma crystallization age of the granite may be explained by mobility of $\mathrm{Rb}$ and/or $\mathrm{Sr}$ in a nonclosed system, although evidence presented below argues for minimal post-emplacement alteration in all granites. In contrast, mineral ages that closely match emplacement ages can be attributed to the absence of post-cooling thermal perturbation. The range of ${ }^{40} \mathrm{Ar} /{ }^{39} \mathrm{Ar}$ ages for the Burnthill Granite (Taylor et al. 1987) suggests that different parts or phases of the pluton cooled at different rates.

\section{LITHOGEOCHEMISTRY}

A total of 68 samples from ten plutons were analyzed in this study. Analytical methods are summarized in Appendix $\mathrm{A}$, and the complete dataset is presented in Appendix B. Average compositions for individual plutons are given in Table 3; these averages were determined by supplementing newly acquired analyses (i.e., the data in Appendix B) with data compiled from Whalen $(1993 ; 23$ samples from 8 plutons) and MacLellan et al. (1990; 33 samples from the Burnthill pluton) (see Appendix A for comments on their analytical methods). Similarly, the geochemical variation and discrimination diagrams (Figs. 7-22) incorporate data from those two sources. Newly acquired analyses of granites from the study area reveal geochemical characteristics very similar to those reported by Whalen (1993); furthermore, in most cases, felsic plutonic rocks of all ages display overall geochemical similarity. Post-emplacement alteration and alkali mobility has been relatively minor based on the $\left(\mathrm{K}_{2} \mathrm{O}+\mathrm{Na}_{2} \mathrm{O}\right)$ vs. $\mathrm{K}_{2} \mathrm{O} /\left(\mathrm{K}_{2} \mathrm{O}+\mathrm{Na}_{2} \mathrm{O}\right)$ diagram of Hughes (1973) (not shown), as almost $90 \%$ of samples plot within the "igneous spectrum" and most of the others are only marginally altered using this criterion. Nevertheless, these slightly altered samples were not included in the geochemical plots discussed herein. Average $\mathrm{Mg \# s} \mathrm{(=100} \mathrm{x} \mathrm{mol.} \mathrm{MgO/}$ $\left(\mathrm{mol} . \mathrm{MgO}+\mathrm{FeO}^{\mathrm{t}}\right)$ for Silurian-Devonian granite plutons range from 18.1 to 34.3 (Table 3); the most evolved granites according to this measure are the Redstone Mountain ( $\mathrm{Mg} \#$ = 18.1), Beadle Mountain (23.0) and Burnthill (24.8) plutons.

Most samples from all plutons are peraluminous according to the aluminum saturation index (ASI) of Shand (1943) (modified by Frost et al. 2001; Fig. 7), although there is some overlap into the metaluminous field. Most plutons are classified as S-type using ASI = 1.1 as the boundary between I- and S-type granites (Chappell and White 1992; Fig. 7). However, the Burnthill Granite shows significant overlap onto the I-type field (Fig. 7) and was interpreted as such (as were Ganderian granites as a whole) by Whalen (1993). Samples from most plutons fall in the fields of both ferroan and magnesian granites on the $\mathrm{Fe}^{*}\left(=\mathrm{FeO}^{\mathrm{t}} /\left(\mathrm{FeO}^{\mathrm{t}}+\mathrm{MgO}\right)\right)$ vs. $\mathrm{SiO}_{2}$ diagram of Frost et al. (2001; Fig. 8). Exceptions are the Redstone Mountain Granite, which plots entirely within the ferroan field (Fig. 8b), and the closely related Juniper Barren and Beadle Mountain plutons (Fig. 8c)-the

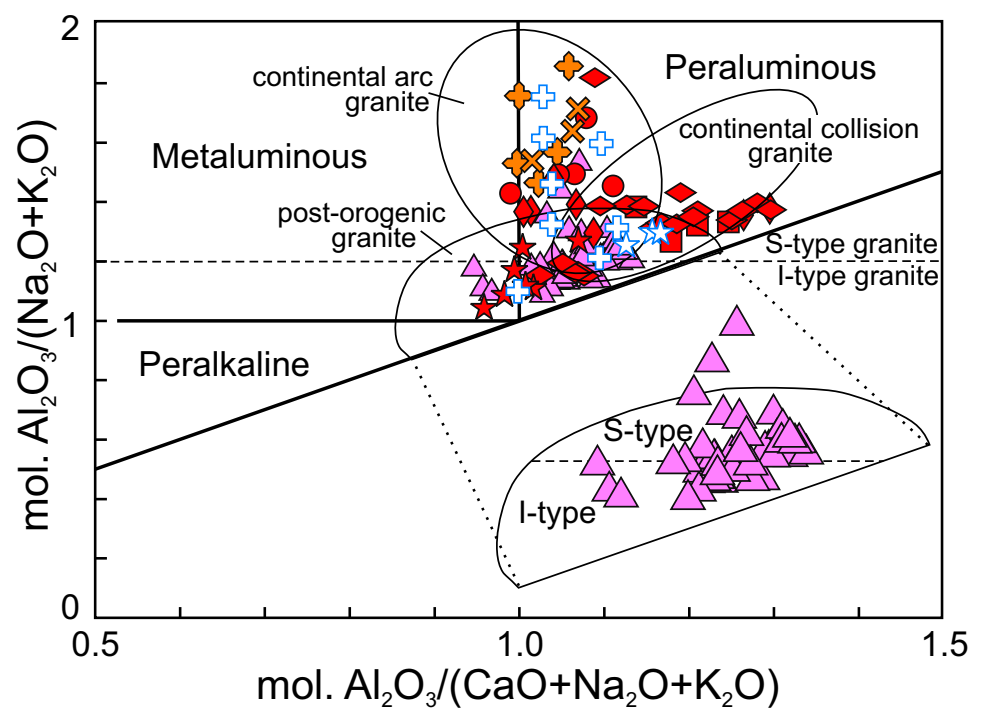

LATE DEVONIAN

$\triangle$ Burnthill Granite

LATE SILURIAN - EARLY DEVONIAN

$\diamond$ Lost Lake Granite

$\square$ Beadle Mountain Granite

- Juniper Barren Granite

Redstone Mountain Granite

$\checkmark$ Nashwaak Granite

Lost Lake Granodiorite

\& Bogan Brook Granodiorite

MIDDLE ORDOVICIAN

§ McKiel Lake Granite

is Little Clearwater Stream Granite

Figure 7. $\mathrm{Al} /(\mathrm{Na}+\mathrm{K})$ vs. $\mathrm{Al} /(\mathrm{Ca}+\mathrm{Na}+\mathrm{K})$ aluminum saturation index (ASI) diagram of Shand (1943) for granites from the central part of the Central plutonic belt, defining the range of peraluminous, metaluminous and peralkaline plutonic rocks. Fields for continental arc, continental collision, and post-orogenic granites are from Maniar and Piccoli (1989). The horizontal dashed line at ASI = 1.1 corresponds to the boundary between I-type (below) and S-type (above) granites (Chappell and White 1992). The post-orogenic field has been expanded slightly to show the distribution of only Burnthill Granite samples. 
Table 3. Average major and trace element compositions of granitoid rock units from the central part of the Central plutonic belt, New Brunswick. $\mathrm{Mg} \#=100 \mathrm{x}$ mol. $\mathrm{MgO} /\left(\mathrm{mol} . \mathrm{MgO}+\mathrm{FeO}^{\mathrm{t}}\right) . \mathrm{n}=$ number of samples.

\begin{tabular}{|c|c|c|c|c|c|c|c|c|c|c|}
\hline Unit & Burnthill & $\begin{array}{c}\text { Beadle } \\
\text { Mountain }\end{array}$ & $\begin{array}{l}\text { Juniper } \\
\text { Barren }\end{array}$ & $\begin{array}{l}\text { Lost Lake } \\
\text { Granite }\end{array}$ & Nashwaak & $\begin{array}{l}\text { Redstone } \\
\text { Mountain }\end{array}$ & $\begin{array}{c}\text { Lost Lake } \\
\text { Granodiorite }\end{array}$ & $\begin{array}{l}\text { Bogan } \\
\text { Brook }\end{array}$ & $\begin{array}{l}\text { Little Clear- } \\
\text { water }\end{array}$ & $\begin{array}{c}\text { McKiel } \\
\text { Lake }\end{array}$ \\
\hline $\mathrm{n}$ & 47 & 6 & 6 & 9 & 20 & 11 & 4 & 6 & 4 & 11 \\
\hline $\mathrm{SiO}_{2}$ & 76.02 & 74.48 & 69.41 & 72.56 & 74.06 & 74.43 & 66.65 & 67.40 & 75.93 & 71.77 \\
\hline $\mathrm{TiO}_{2}$ & 0.16 & 0.24 & 0.61 & 0.28 & 0.21 & 0.23 & 0.62 & 0.73 & 0.28 & 0.44 \\
\hline $\mathrm{Al}_{2} \mathrm{O}_{3}$ & 12.76 & 13.55 & 14.60 & 14.40 & 13.76 & 12.74 & 16.03 & 15.00 & 12.65 & 13.68 \\
\hline $\mathrm{Fe}_{2} \mathrm{O}_{3}{ }^{\mathrm{t}}$ & 1.42 & 1.92 & 3.73 & 2.00 & 1.71 & 2.19 & 4.01 & 4.56 & 1.79 & 2.99 \\
\hline $\mathrm{MnO}$ & 0.05 & 0.04 & 0.07 & 0.05 & 0.04 & 0.04 & 0.08 & 0.08 & 0.03 & 0.05 \\
\hline $\mathrm{MgO}$ & 0.25 & 0.35 & 0.99 & 0.48 & 0.35 & 0.27 & 1.35 & 1.39 & 0.45 & 0.65 \\
\hline $\mathrm{CaO}$ & 0.71 & 0.69 & 1.98 & 1.32 & 0.85 & 0.85 & 3.63 & 2.73 & 0.50 & 1.74 \\
\hline $\mathrm{Na}_{2} \mathrm{O}$ & 3.50 & 3.09 & 3.18 & 3.53 & 3.39 & 4.00 & 3.77 & 3.25 & 2.55 & 3.32 \\
\hline $\mathrm{K}_{2} \mathrm{O}$ & 4.57 & 4.75 & 4.19 & 4.21 & 4.39 & 3.81 & 2.62 & 3.33 & 4.14 & 3.90 \\
\hline $\mathrm{P}_{2} \mathrm{O}_{5}$ & 0.04 & 0.16 & 0.18 & 0.17 & 0.16 & 0.04 & 0.18 & 0.16 & 0.09 & 0.14 \\
\hline$M g \#$ & 24.8 & 23.0 & 34.3 & 27.8 & 26.4 & 18.1 & 39.0 & 37.2 & 33.9 & 28.2 \\
\hline As & 0.8 & 0.5 & 0.3 & 0.3 & 1.2 & 13.3 & 2.8 & 0.6 & 11.9 & 0.3 \\
\hline $\mathrm{Au}$ & 1.4 & 1.0 & 1.5 & 2.4 & 1.0 & 1.4 & 0.4 & 1.8 & 1.0 & 2.5 \\
\hline $\mathrm{Ba}$ & 134 & 232 & 473 & 359 & 267 & 567 & 320 & 483 & 284 & 439 \\
\hline $\mathrm{Be}$ & 8 & 3 & 4 & 5 & 5 & 4 & 5 & 4 & 3 & 3 \\
\hline $\mathrm{Bi}$ & 5.4 & 2.4 & 0.6 & 1.3 & 0.9 & 3.5 & 0.2 & 1.8 & 0.4 & 0.2 \\
\hline Co & 1.7 & 2.3 & 7.0 & 3.2 & 2.1 & 2.3 & 8.7 & 10.2 & 2.5 & 4.9 \\
\hline $\mathrm{Cr}$ & 18 & 18 & 30 & 14 & 13 & 12 & 11 & 29 & 18 & 21 \\
\hline Cs & 8.0 & 7.2 & 6.6 & 6.4 & 8.1 & 2.2 & 5.5 & 8.3 & 6.3 & 4.7 \\
\hline $\mathrm{Cu}$ & 9 & 7 & 9 & 6 & 5 & 13 & 9 & 17 & 5 & 7 \\
\hline $\mathrm{F}^{*}$ & 812 & & & 534 & 561 & 555 & 490 & 678 & & 681 \\
\hline $\mathrm{Ga}$ & 20 & 18 & 20 & 20 & 18 & 19 & 20 & 19 & 16 & 18 \\
\hline Hf & 4.2 & 3.3 & 5.5 & 3.5 & 2.9 & 7.2 & 5.5 & 5.8 & 4.3 & 5.8 \\
\hline Mo & 1.4 & 1.5 & 0.9 & 0.7 & 0.9 & 1.0 & 0.4 & 1.0 & 1.0 & 0.7 \\
\hline $\mathrm{Nb}$ & 25.5 & 13.1 & 13.0 & 14.2 & 12.0 & 20.7 & 12.5 & 13.6 & 12.7 & 13.1 \\
\hline $\mathrm{Ni}$ & 3 & 4 & 8 & 4 & 4 & 4 & 6 & 10 & 4 & 6 \\
\hline $\mathrm{Pb}$ & 30 & 26 & 23 & 21 & 23 & 9 & 14 & 18 & 16 & 20 \\
\hline $\mathrm{Rb}$ & 391 & 250 & 183 & 225 & 212 & 158 & 124 & 144 & 174 & 156 \\
\hline $\mathrm{Sb}$ & 0.1 & 0.2 & 0.2 & 0.1 & 0.3 & 0.2 & 0.3 & 0.3 & 2.9 & 0.2 \\
\hline $\mathrm{Sc}$ & 5.2 & 5.0 & 8.9 & 5.1 & 5.1 & 5.8 & 9.3 & 13.3 & 5.3 & 7.9 \\
\hline Sn & 12.4 & 8.3 & 5.4 & 9.6 & 10.7 & 5.6 & 4.5 & 2.9 & 3.9 & 4.8 \\
\hline $\mathrm{Sr}$ & 55 & 52 & 149 & 89 & 59 & 100 & 249 & 181 & 46 & 117 \\
\hline $\mathrm{Ta}$ & 6.60 & 2.20 & 1.55 & 2.31 & 2.16 & 1.81 & 1.51 & 1.27 & 1.48 & 1.21 \\
\hline Th & 36.20 & 15.25 & 16.93 & 13.33 & 14.71 & 25.43 & 10.47 & 14.21 & 18.53 & 15.55 \\
\hline $\mathrm{U}$ & 16.31 & 5.30 & 4.35 & 4.29 & 4.17 & 7.35 & 5.12 & 4.57 & 4.11 & 3.14 \\
\hline $\mathrm{V}$ & 11 & 19 & 59 & 22 & 17 & 11 & 61 & 78 & 22 & 35 \\
\hline W & 9.0 & 2.3 & 1.1 & 3.7 & 1.4 & 1.0 & 0.6 & 0.6 & 1.1 & 1.5 \\
\hline $\mathrm{Y}$ & 60.3 & 34.2 & 34.7 & 19.1 & 25.3 & 53.4 & 17.7 & 28.9 & 37.2 & 32.7 \\
\hline $\mathrm{Zn}$ & 37 & 40 & 57 & 46 & 34 & 17 & 59 & 53 & 20 & 44 \\
\hline $\mathrm{Zr}$ & 131 & 116 & 213 & 117 & 94 & 233 & 204 & 205 & 151 & 205 \\
\hline $\mathrm{La}$ & 25.77 & 20.70 & 34.54 & 27.75 & 20.42 & 56.52 & 35.29 & 39.08 & 30.53 & 35.80 \\
\hline $\mathrm{Ce}$ & 66.71 & 42.48 & 71.27 & 52.09 & 44.51 & 110.70 & 66.77 & 72.37 & 63.13 & 71.47 \\
\hline $\operatorname{Pr}$ & 8.20 & 5.19 & 8.39 & 4.02 & 4.48 & 12.24 & 7.83 & 6.54 & 7.21 & 6.25 \\
\hline
\end{tabular}


Table 3. Continued.

\begin{tabular}{|c|c|c|c|c|c|c|c|c|c|c|}
\hline Unit & Burnthill & $\begin{array}{c}\text { Beadle } \\
\text { Mountain }\end{array}$ & $\begin{array}{l}\text { Juniper } \\
\text { Barren }\end{array}$ & $\begin{array}{l}\text { Lost Lake } \\
\text { Granite }\end{array}$ & Nashwaak & $\begin{array}{l}\text { Redstone } \\
\text { Mountain }\end{array}$ & $\begin{array}{c}\text { Lost Lake } \\
\text { Granodiorite }\end{array}$ & $\begin{array}{l}\text { Bogan } \\
\text { Brook }\end{array}$ & $\begin{array}{l}\text { Little Clear- } \\
\text { water }\end{array}$ & $\begin{array}{c}\text { McKiel } \\
\text { Lake }\end{array}$ \\
\hline $\mathrm{n}$ & 47 & 6 & 6 & 9 & 20 & 11 & 4 & 6 & 4 & 11 \\
\hline $\mathrm{Sm}$ & 6.98 & 4.62 & 6.66 & 4.24 & 3.96 & 9.60 & 5.00 & 5.74 & 5.39 & 5.75 \\
\hline $\mathrm{Eu}$ & 0.34 & 0.56 & 1.18 & 0.73 & 0.51 & 1.18 & 1.17 & 1.35 & 0.63 & 1.11 \\
\hline Dy & 9.11 & 5.38 & 5.79 & 2.94 & 3.97 & 9.43 & 3.68 & 3.71 & 5.70 & 5.13 \\
\hline Ho & 1.60 & 1.03 & 1.13 & 0.51 & 0.77 & 1.92 & 0.70 & 0.70 & 1.16 & 1.00 \\
\hline Er & 4.98 & 3.11 & 3.19 & 1.45 & 2.27 & 5.59 & 1.86 & 2.05 & 3.39 & 2.98 \\
\hline $\mathrm{Tm}$ & 0.86 & 0.52 & 0.49 & 0.22 & 0.36 & 0.88 & 0.27 & 0.31 & 0.53 & 0.48 \\
\hline $\mathrm{Yb}$ & 6.61 & 3.52 & 3.13 & 1.63 & 2.40 & 5.83 & 1.51 & 2.74 & 3.57 & 3.10 \\
\hline
\end{tabular}

* Reported by MacLellan et al . (1990) and Whalen (1993); average is based on fewer analyses than for other elements. Whalen (1993) also reports $\mathrm{Li}$ analyses. Major oxides are in wt\%, and trace elements in ppm, except for $\mathrm{Au}(\mathrm{ppb})$.

dominantly muscovite-bearing Beadle Mountain Granite falls mainly in the ferroan field, whereas the dominantly biotite-bearing Juniper Barren Granite falls mainly in the magnesian field. The modified alkali-lime index (MALI = $\left.\left(\mathrm{Na}_{2} \mathrm{O}+\mathrm{K}_{2} \mathrm{O}-\mathrm{CaO}\right)\right)$ of Frost et al. (2001) demonstrates that most samples from all plutons are calc-alkalic, with minor overlap onto the adjacent alkali-calcic and calcic fields (Fig. 9). The normative mineralogy-based Q-ANOR diagram of Streckeisen and LeMaitre (1979) shows that intrusive rock types in the granitic plutons include monzogranite, syenogranite, alkali-feldspar granite, and rare granodiorite (Fig. 10). On this diagram, empirically-derived compositional trends (Whalen and Frost 2013; Hildebrand and Whalen 2014) again illustrate a dominant calc-alkalic character.

Trace-element variation diagrams highlight some of the similarities and differences among the various plutonic rock units. On a Sr vs. Rb plot (considered to represent primary abundances of these elements because of the aforementioned low degree of alkali-element mobility), the Burnthill Granite is notably enriched in $\mathrm{Rb}$, whereas the Redstone Mountain Granite has generally lower concentrations compared to all other plutons, which cluster in the central part of the diagram (Fig. 11a). On a U vs. Th diagram, the Burnthill Granite forms a distinct population characterized by much higher abundances of both elements (Fig. 11b). The Redstone Mountain Granite, and the combined Juniper Barren and Beadle Mountain plutons, each form well-defined clusters, whereas the Nashwaak and Lost Lake plutons show a wide range of Th values. On an $\mathrm{Y}$ vs. $\mathrm{TiO}_{2}$ diagram, samples of Burnthill Granite define a dense cluster having a negative slope (Fig. 12a), resembling the distribution of Redstone Mountain samples (Fig. 12b). In contrast, other Silurian-
Devonian granites (Fig. 12b), as well as the Ordovician granites (Fig. 12c), plot on a trend having a flat to slightly positive slope, reflecting a wide range of $\mathrm{TiO}_{2}$ over a comparatively restricted range of $\mathrm{Y}$ abundance. $\mathrm{A} \mathrm{TiO}_{2}$ vs. $\mathrm{Zr}$ plot shows that most of the data from all plutons define a concave-upward curve having a moderate to steep positive slope (Figs. 13a-c), whereas the Redstone Mountain samples form a separate trend characterized by a slightly positive to flat slope (Fig. 13b). Rare-earth element (REE) profiles also illustrate the distinctiveness of the Burnthill and Redstone Mountain granites; the former (Fig. 14a) has a significantly flatter slope $(\mathrm{La} / \mathrm{Yb}=3.9)$ and more prominent negative $\mathrm{Eu}$ anomaly $(\mathrm{Sm} / \mathrm{Eu}=20.5)$ compared to all other plutons (Figs. $14 \mathrm{~b}-\mathrm{d}$ ), in which $\mathrm{La} / \mathrm{Yb}$ ranges from 5.9 to 23.4 and $\mathrm{Sm} / \mathrm{Eu}$ from 4.3 to 8.6. The Redstone Mountain profile (Fig. 14b) has the same slope as other Silurian-Devonian granites, but it contains much higher absolute REE abundances (average $\Sigma \mathrm{REE}=271 \mathrm{ppm}$ ) compared to the other units (average $\Sigma$ REE $=106$ to $175 \mathrm{ppm}$; Table 3). Aside from the Redstone Mountain pluton, profiles for Silurian-Devonian granites (Fig. 14b) and Ordovician granites (Fig. 14d) are essentially identical (see also Whalen 1993). The Lost Lake Granite and Lost Lake Granodiorite display the steepest slopes (La/ $\mathrm{Yb}=17.0$ and 23.4, respectively) because of their slight depletion in heavy REE. The granodiorites (Fig. 14c) lack a significant Eu anomaly and have the lowest $\mathrm{Sm} / \mathrm{Eu}$ (4.3).

In the genetic/petrologic classification of Appalachian granites devised by Whalen (1993) and Currie (1995), all plutons in the study area, except for the Burnthill and Redstone Mountain granites, are grouped together as either deformed ("type 5a": Ordovician) or massive ("type 7a": Silurian-Devonian), chemically and isotopically 

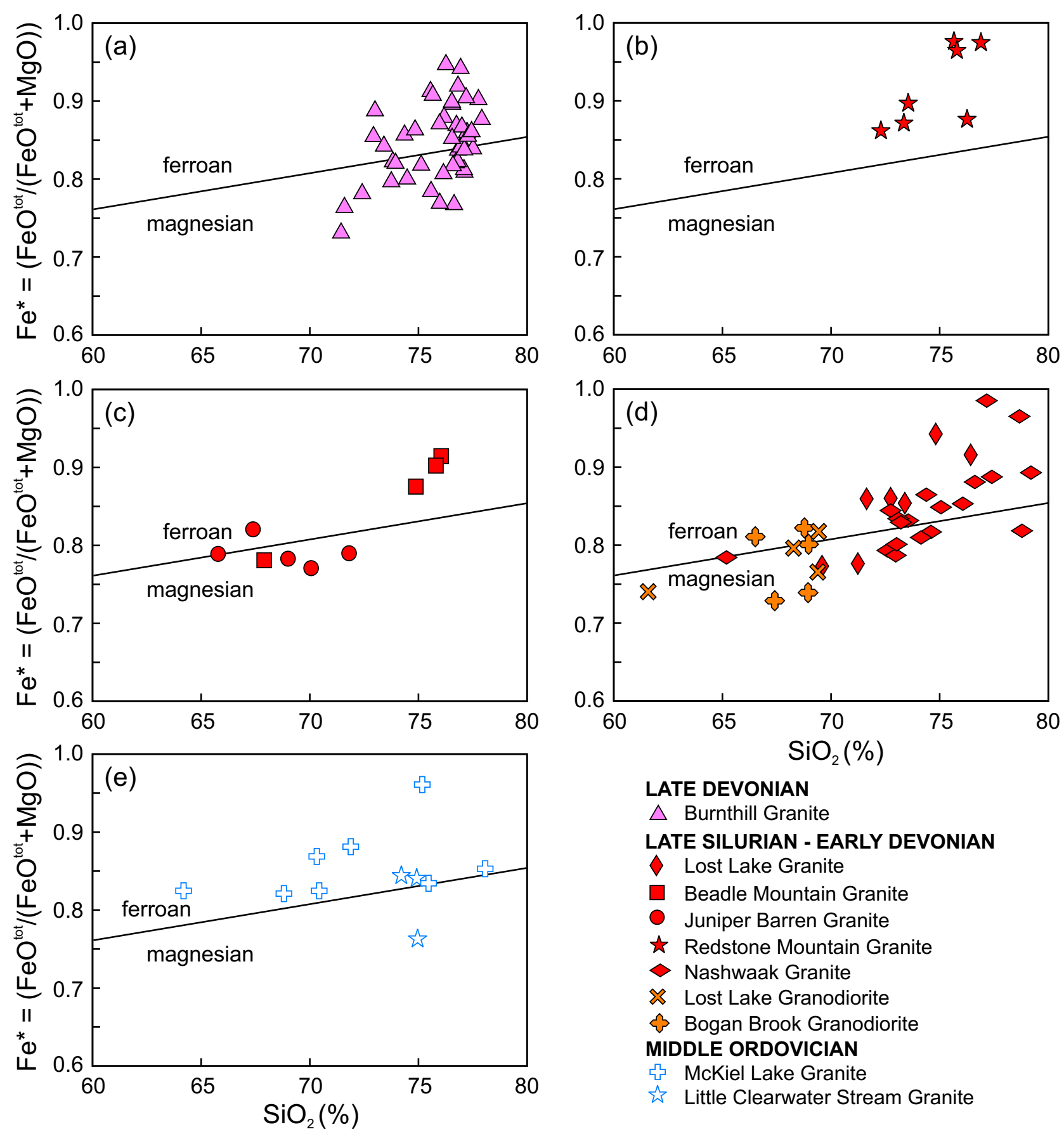

Figure 8. $\mathrm{FeO}^{\mathrm{t}} /\left(\mathrm{FeO}^{\mathrm{t}}+\mathrm{MgO}\right)$ vs. $\mathrm{SiO}_{2}$ diagram for plutonic rocks from the central part of the Central plutonic belt, separating rocks into ferroan and magnesian suites based on the relative degree of iron enrichment during differentiation (Frost et al. 2001). The field boundary closely coincides with the tholeiitic-calc-alkaline boundary of Miyashiro (1974) for this $\mathrm{SiO}_{2}$ interval. (a) Burnthill Granite; (b) Redstone Mountain Granite; (c) Juniper Barren and Beadle Mountain granites; (d) Nashwaak and Lost Lake granites, and Bogan Brook and Lost Lake granodiorites; (e) McKiel Lake and Little Clearwater Brook (Ordovician) granites.

indistinguishable peraluminous granites. The Redstone Mountain Granite was considered a "type 8", composite pluton that forms a bimodal association with spatially and (presumably) genetically related mafic intrusive rocks, in this case the Clearwater Brook Gabbro (Fig. 1) and scattered mafic plugs and dykes. This bimodal association is consistent 

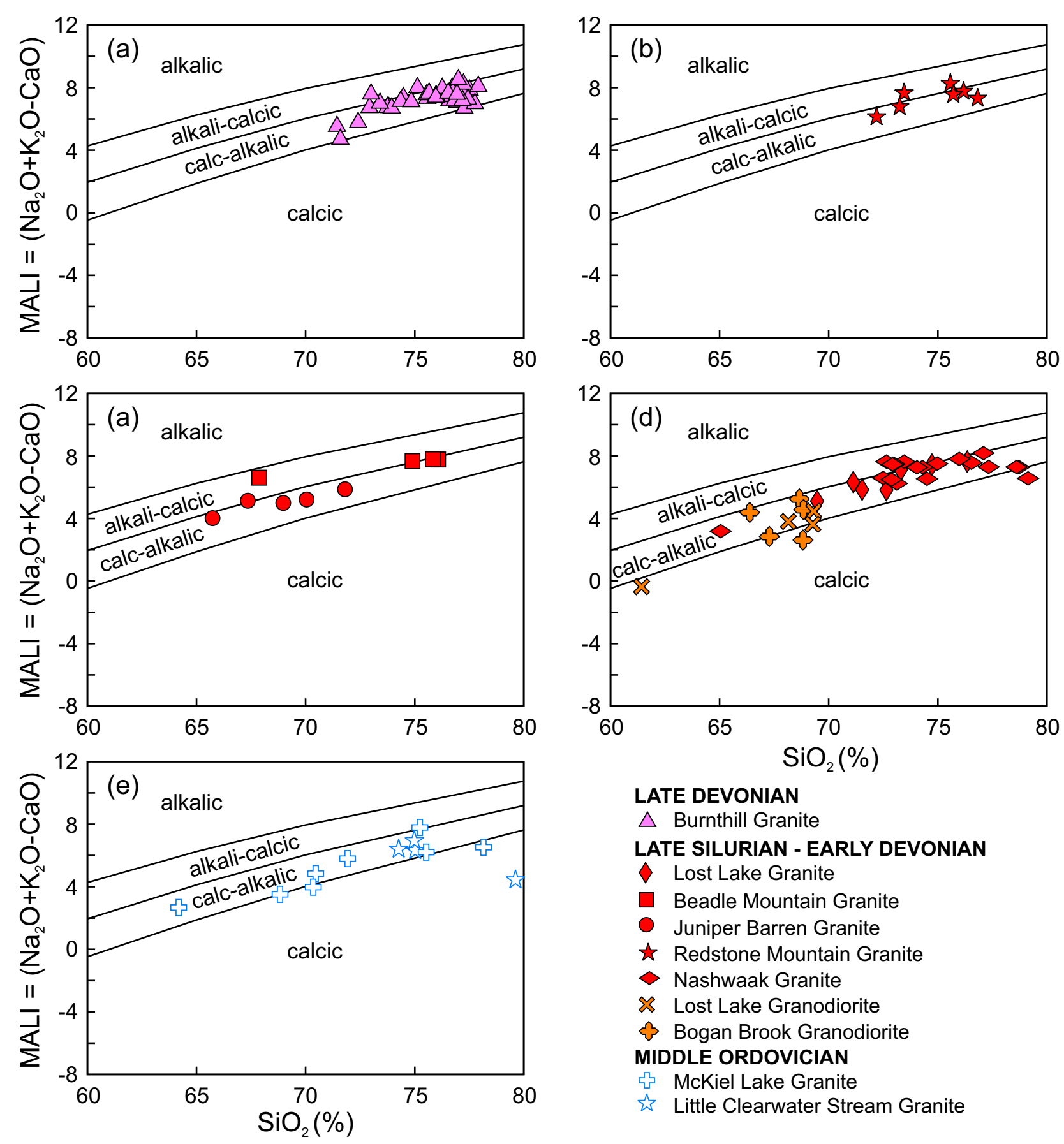

\section{LATE DEVONIAN}

$\triangle$ Burnthill Granite

LATE SILURIAN - EARLY DEVONIAN

$\diamond$ Lost Lake Granite

$\square$ Beadle Mountain Granite

- Juniper Barren Granite

Redstone Mountain Granite

$\checkmark$ Nashwaak Granite

Lost Lake Granodiorite

\& Bogan Brook Granodiorite MIDDLE ORDOVICIAN

¡ McKiel Lake Granite

论 Little Clearwater Stream Granite

Figure 9. Modified alkali-like index $\left(\mathrm{MALI}=\mathrm{Na}_{2} \mathrm{O}+\mathrm{K}_{2} \mathrm{O}-\mathrm{CaO}\right)$ vs. $\mathrm{SiO}_{2}$ for plutonic rocks from the central part of the Central plutonic belt, with fields defined by Frost et al. (2001). (a) Burnthill Granite; (b) Redstone Mountain Granite; (c) Juniper Barren and Beadle Mountain granites; (d) Nashwaak and Lost Lake granites, and Bogan Brook and Lost Lake granodiorites; (e) McKiel Lake and Little Clearwater Brook (Ordovician) granites.

with the close spatial and genetic association with (and geochemical similarity to) bimodal volcanic rocks of the Costigan Mountain Formation (Tobique Group; Walker and Clark 2012). The Burnthill Granite was included in "type 9b" plutons, namely evolved, high-silica granites lacking mafic phases and exhibiting large degrees of crystal fractionation (Whalen 1993). It is clear that the new analytical data obtained on these plutons and the classification diagrams discussed in this section support the interpretations and conclusions of Whalen (1993) and Currie (1995). 

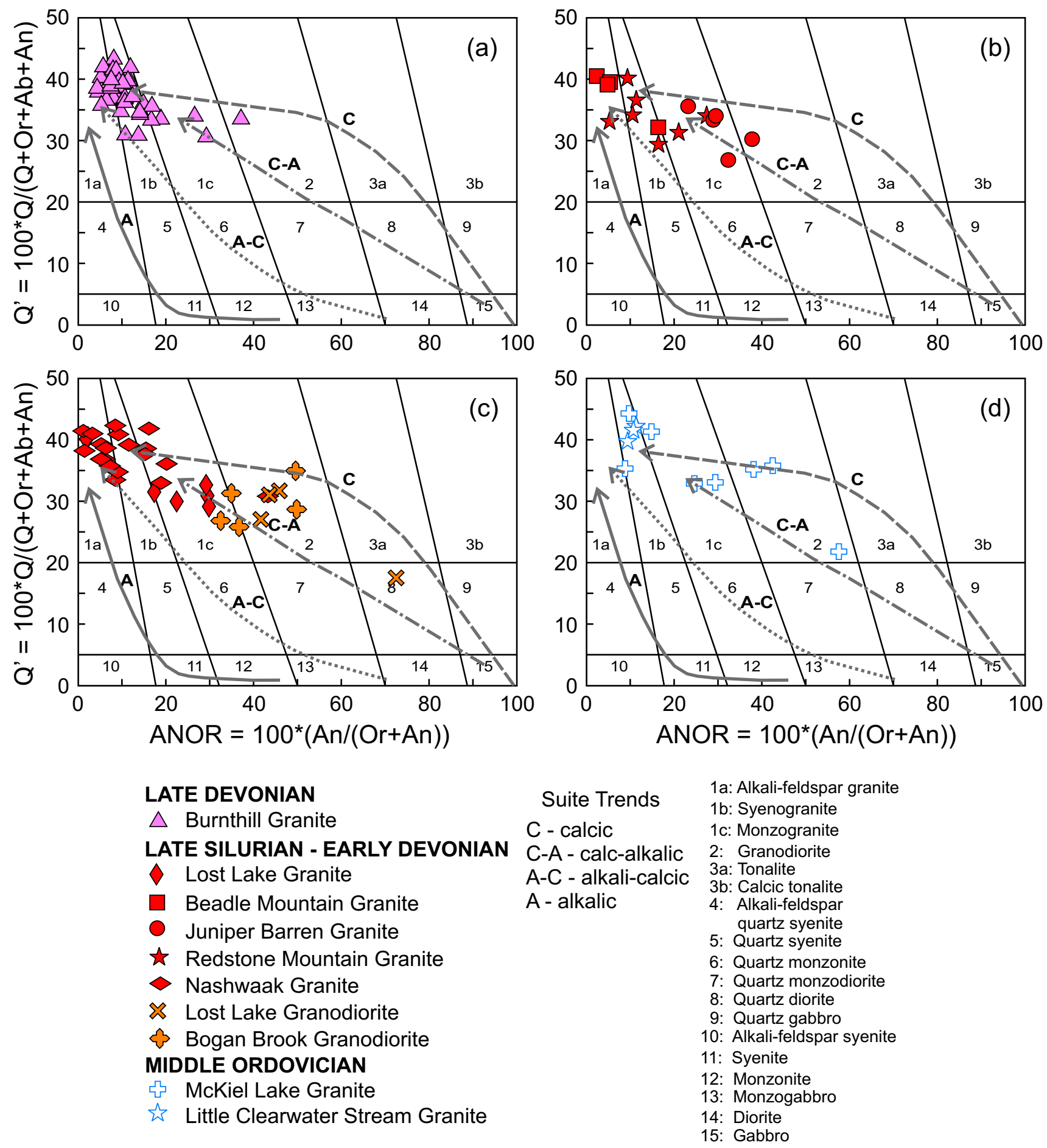

Figure 10. Q-ANOR normative mineralogy-based classification diagram of Streckeisen and LeMaitre (1979) for plutonic rocks from the central part of the Central plutonic belt, with compositional trends for calcic, calc-alkalic, alkali-calcic, and alkalic suites defined by Whalen and Frost (2013) and Hildebrand and Whalen (2014). (a) Burnthill Granite; (b) Redstone Mountain, Juniper Barren, and Beadle Mountain granites; (c) Nashwaak and Lost Lake granites, and Bogan Brook and Lost Lake granodiorites; (d) McKiel Lake and Little Clearwater Brook (Ordovician) granites. 

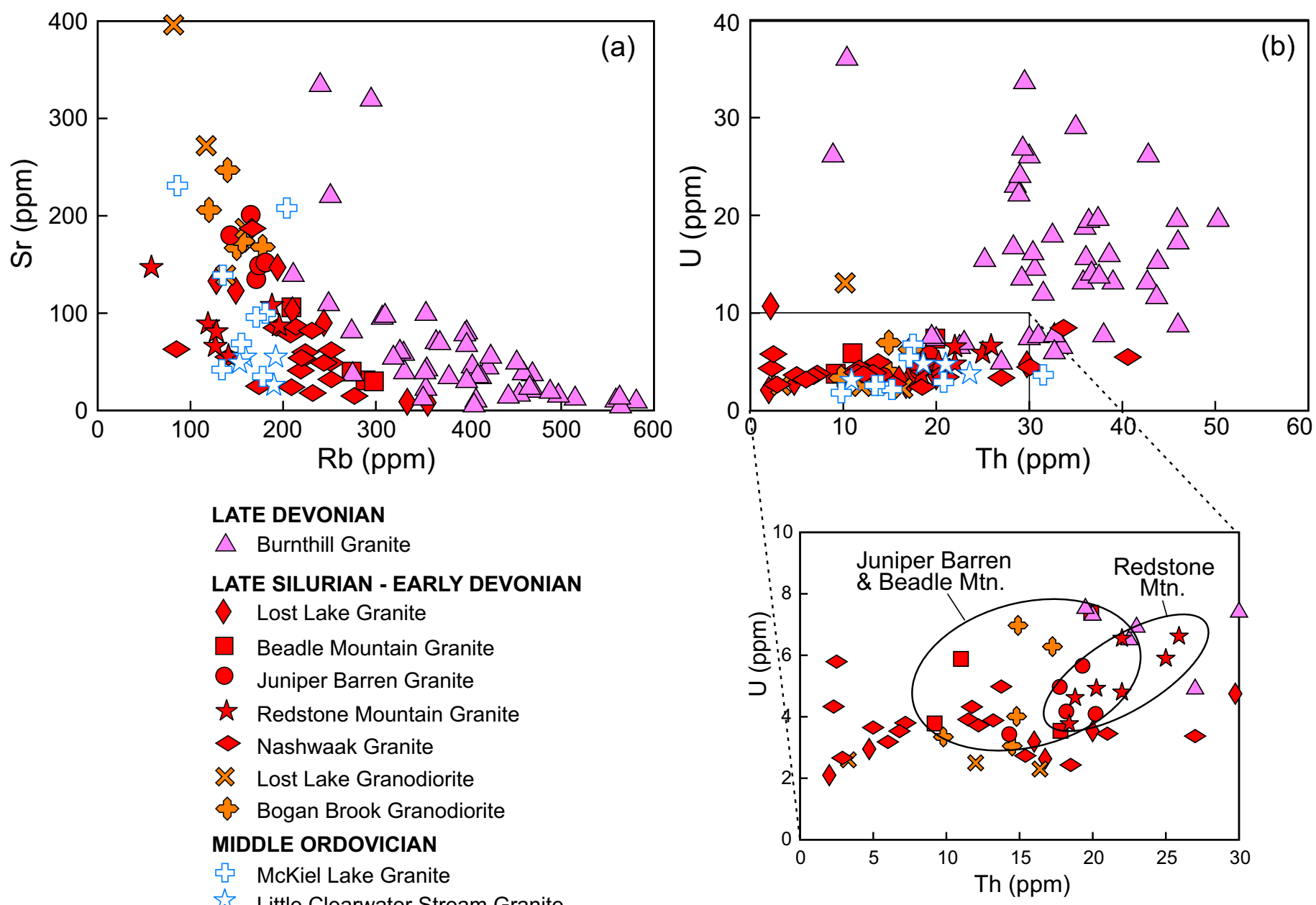

Figure 11. (a) Sr vs. $\mathrm{Rb}$, and (b) U vs. Th variation diagrams for granites and granodiorites from the central part of the Central plutonic belt.

\section{TECTONIC CONTEXT: SOURCE AND SETTING}

Most plutons display some degree of overlap between the volcanic arc and within-plate fields on the $\mathrm{Rb}$ vs. $\mathrm{Nb}+\mathrm{Y}$ tectonic discrimination diagram (Pearce et al. 1984; Pearce 1996; Fig. 15). However, the Burnthill Granite (Fig. 15a) and especially the Redstone Mountain Granite (Fig. 15b) more closely resemble within-plate granites, whereas the Lost Lake, Nashwaak, and Bogan Brook plutons (Fig. 15d) dominantly resemble volcanic arc granites. Ordovician granites fall within or very close to the volcanic arc field (Fig. 15e), which is somewhat at odds with Whalen (1993) and Whalen et al. (1998), who reported that Ordovician granites in the Gander zone are within-plate types except for intrusions near Woodstock that are genetically related to arc volcanic rocks of the Meductic Group. Aside from the Burnthill pluton, most data points fall within the domain of post-collisional granites delineated by Pearce (1996). Similar overlap of data points between syn- and post-collision and volcanic arc fields is noted on the Hf$\mathrm{Rb}-\mathrm{Ta}$ ternary diagram of Harris et al. (1986) (Fig. 16), and on the major element-based Shand index with fields defined by Maniar and Piccoli (1989) (Fig. 7). However, on both of these diagrams, the Burnthill Granite plots almost exclusively within the syn- or post-collisional fields.

The peraluminous nature of most granite plutons points to a significant supracrustal component in the source; this is supported by the close spatial relationship with the Miramichi Group and Trousers Lake Metamorphic Suite, and the common presence of xenoliths or roof pendants of partially assimilated paragneiss in many plutons. Furthermore, REE profiles of these sedimentary and metasedimentary rocks are very similar to those of most granites (Fig. 14), implying a genetic link. A very similar setting exists in the Gander zone of northeastern Newfoundland, where SilurianDevonian granites are hosted by correlative sedimentary rocks of the Gander Group and paragneiss and migmatite of the Hare Bay Gneiss (Schofield and D'Lemos 2000). In 

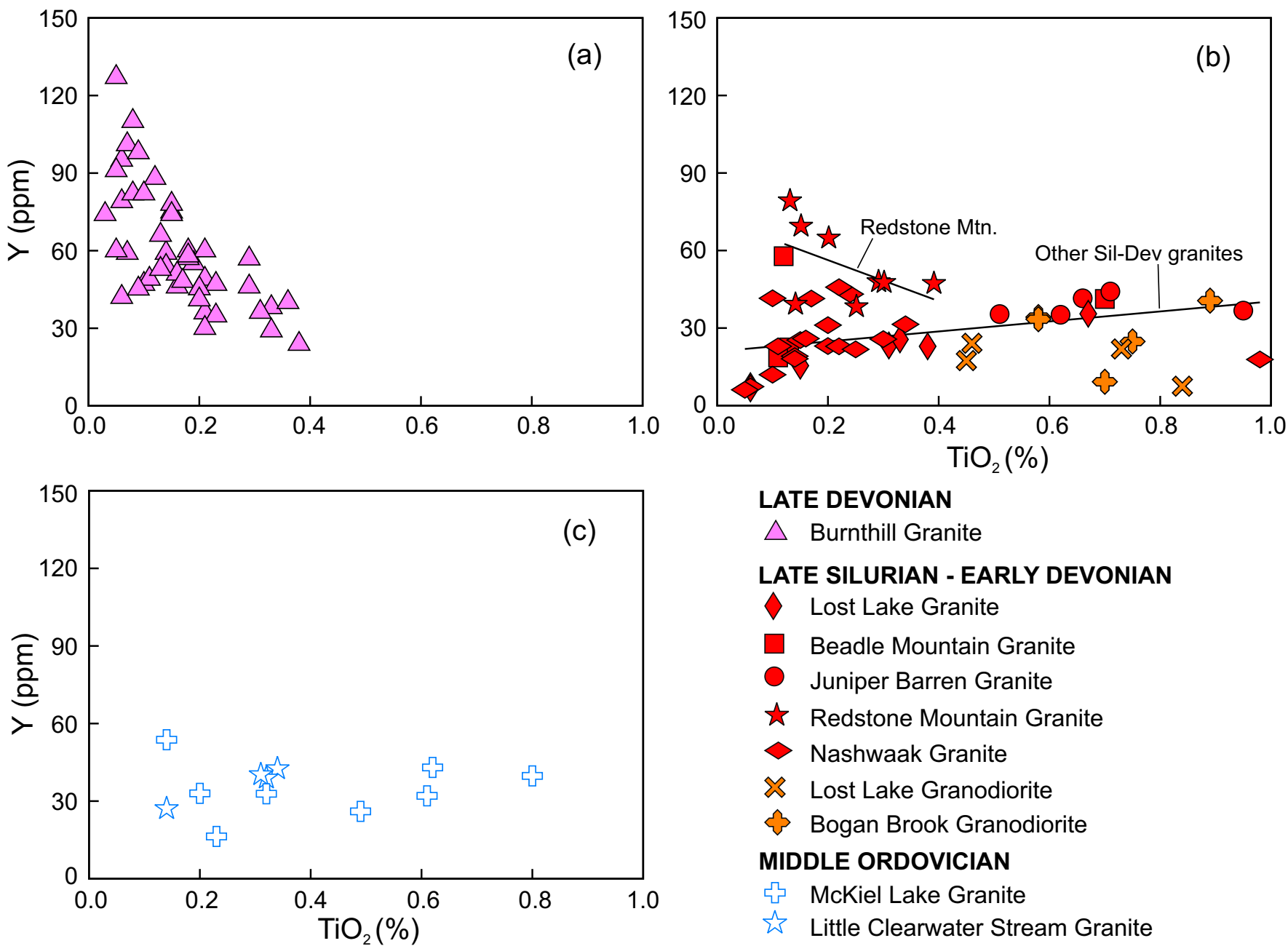

\section{LATE DEVONIAN}

$\triangle$ Burnthill Granite

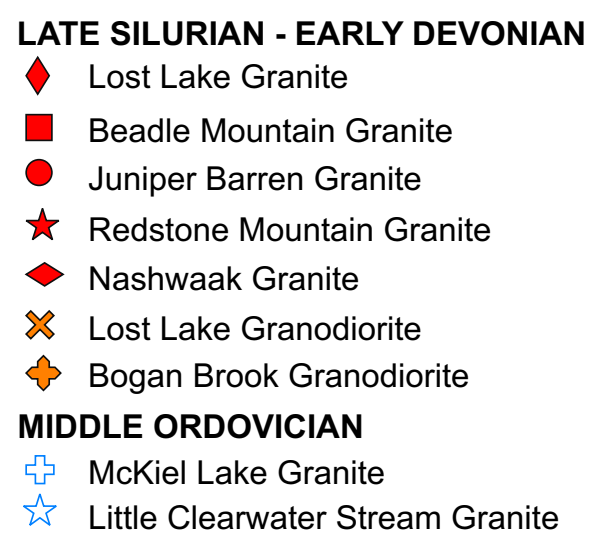

Figure 12. $\mathrm{Y}$ vs. $\mathrm{TiO}_{2}$ variation diagrams for (a) Late Devonian granite, (b) Late Silurian-Early Devonian granites and granodiorites, and (c) Ordovician granites from the central part of the Central plutonic belt. In (b), note the discordant trend defined by Redstone Mountain samples compared to other Silurian-Devonian granites.

spite of this, $\mathrm{Sr}, \mathrm{Nd}$, and $\mathrm{O}$ isotope studies in both $\mathrm{New}$ Brunswick and Newfoundland (Kerr et al. 1995; Whalen et al. 1996; Schofield and D'Lemos 2000) agree that no single source or binary mixing product could unequivocally produce the isotopic signatures of the Silurian-Devonian Ganderian granites, and invoke contributions from mantle, infracrustal and supracrustal sources. As pointed out by Pearce (1996), post-collisional granites in particular are difficult to classify because of the range of potential sources, and that, for example, interaction between mantle sources and the crust tend to move compositions into the volcanic arc field on a $\mathrm{Rb}$ vs. $(\mathrm{Nb}+\mathrm{Y}$ ) diagram (Fig. 15).

Similar Nd isotope compositions and Mesoproterozoic $\mathrm{T}_{\mathrm{DM}}$ model ages in granites and host (meta)sedimentary rocks in Newfoundland (Kerr et al. 1995; Schofield and D'Lemos 2000) suggest that both are ultimately sourced, at least in part, from a common Ganderian basement. Similarly, Whalen et al. (1996) argued that SilurianDevonian granites in New Brunswick were likely derived by bulk assimilation of Mesoproterozoic Ganderian basement and Gander zone supracrustal rocks by an enriched asthenospheric melt. The influence of this mantle source is locally seen in gabbros with $\varepsilon_{\mathrm{Nd}}(\mathrm{T})$ of +1.2 to +2.3 (Whalen et al. 1996); in the study area, the Clearwater Brook and Becaguimec Lake gabbros (Fig. 1) are interpreted to be the same age as those sampled by Whalen et al. (1996).

Whalen et al. (1996) and Schofield and D'Lemos (2000) attributed the heat source that generated Silurian-Devonian granites to the introduction of asthenospheric mantle following either lithospheric delamination of collisionthickened subcontinental lithosphere (e.g., Nelson 1992), or breakoff of the subducting Tetagouche backarc oceanic 

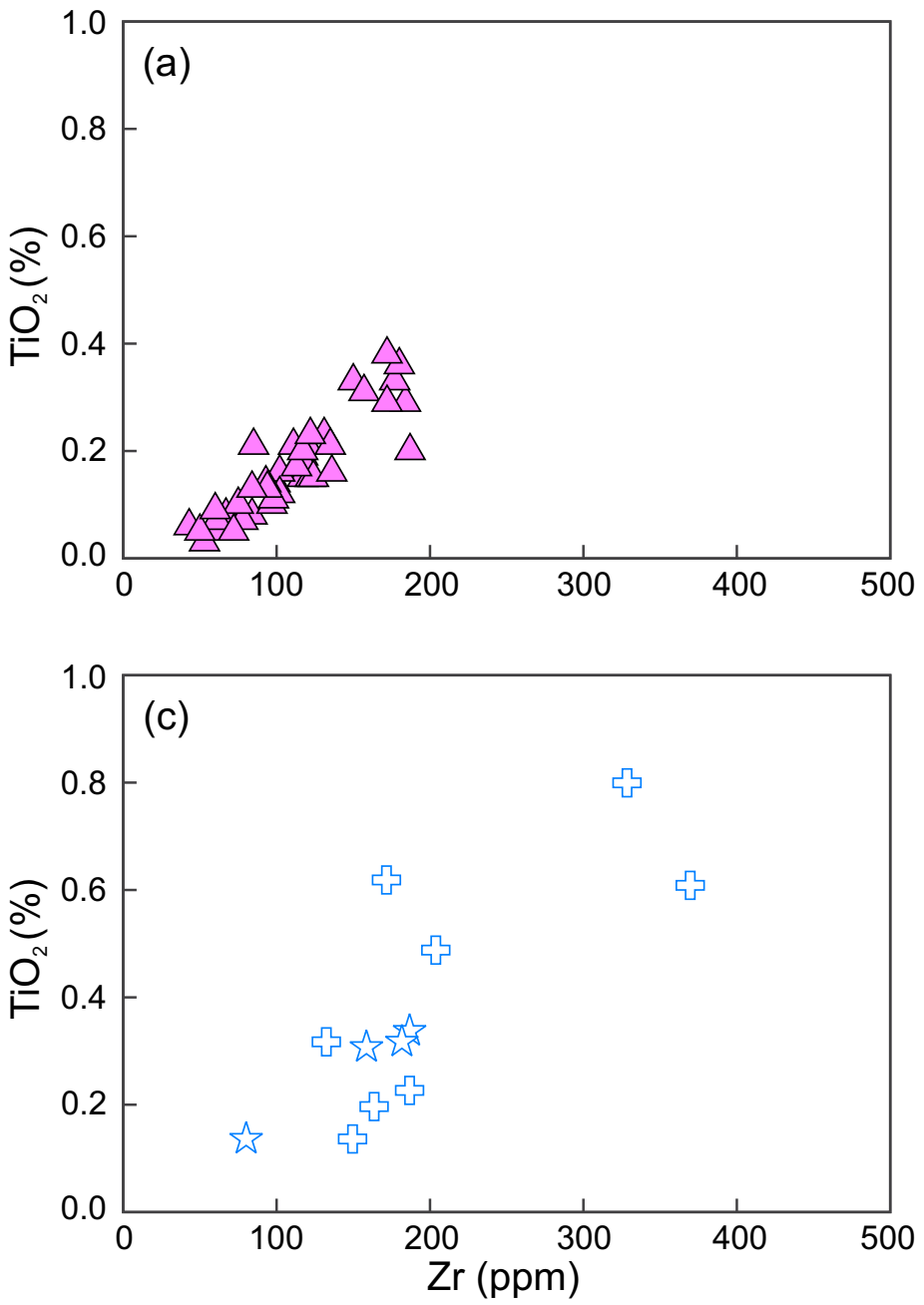

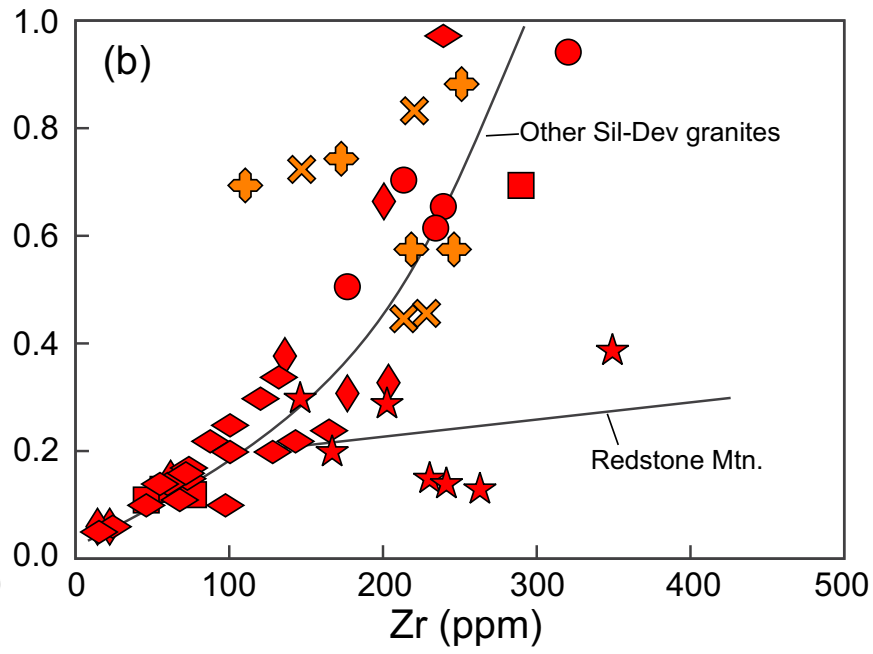

LATE DEVONIAN

$\triangle$ Burnthill Granite

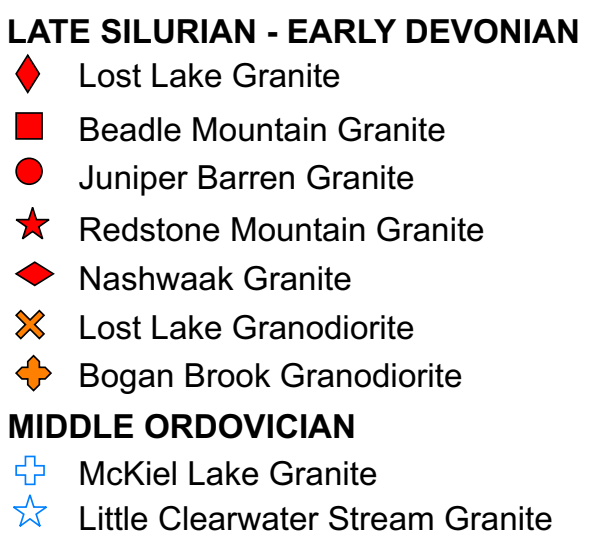

Figure 13. $\mathrm{TiO}_{2}$ vs. $\mathrm{Zr}$ variation diagrams for (a) Late Devonian granite, (b) late Silurian-Early Devonian granites and granodiorites, and (c) Ordovician granites from the central part of the Central plutonic belt. In (b), the Redstone Mountain Granite again defines a distinct trend that is discordant with all other granites.

lithosphere (e.g., Davies and von Blanckenburg 1995). Since both of these scenarios are typically followed by rapid isostatic uplift and gravitational instability, late Silurian exhumation of the Brunswick Subduction Complex and subsequent $\mathrm{D}_{3}$ extensional collapse in the Miramichi Highlands (van Staal and de Roo 1995; van Staal et al. 2003, 2009) could be explained by ca. mid-Silurian breakoff of the Tetagouche slab. However, the Nd isotope geochemistry and $\mathrm{T}_{\mathrm{DM}}$ model ages of Ganderian granitoid plutons in both New Brunswick and Newfoundland (Kerr et al. 1995; Whalen et al. 1996; Schofield and D'Lemos 2000) do not support the introduction of juvenile asthenospheric material during the late Silurian. This is consistent with $\mathrm{Nd}$ isotope data from late Silurian-Early Devonian basalts in northern New Brunswick, where the range in $\varepsilon_{\mathrm{Nd}}(T)$ values and depleted mantle ages also argue against the involvement of juvenile asthenospheric mantle in the genesis of the volcanic rocks (Dostal et al. in press). Furthermore, the chemistry of granites from the Central plutonic belt does not match that of slab breakoff-related granitoid suites documented by Hildebrand and Whalen (2014) (Fig. 17).

An alternative model put forward by van Staal et al. (2009) invokes westerly, flat-slab subduction of Avalonia beneath composite Laurentia (first proposed by Murphy et al. 1999), analogous to the Laramide orogeny in the western USA, to explain overlapping arc, within-plate, and collisional geochemical signatures, late Silurian-Early Devonian regional uplift, and northwestward (present coordinates) migration of Acadian deformation (cf., Bradley et al. 2000). In New Brunswick, Silurian-Devonian magmatism and Acadian deformation are broadly contemporaneous, ranging from ca. 421 to $407 \mathrm{Ma}$, based on the ages of 

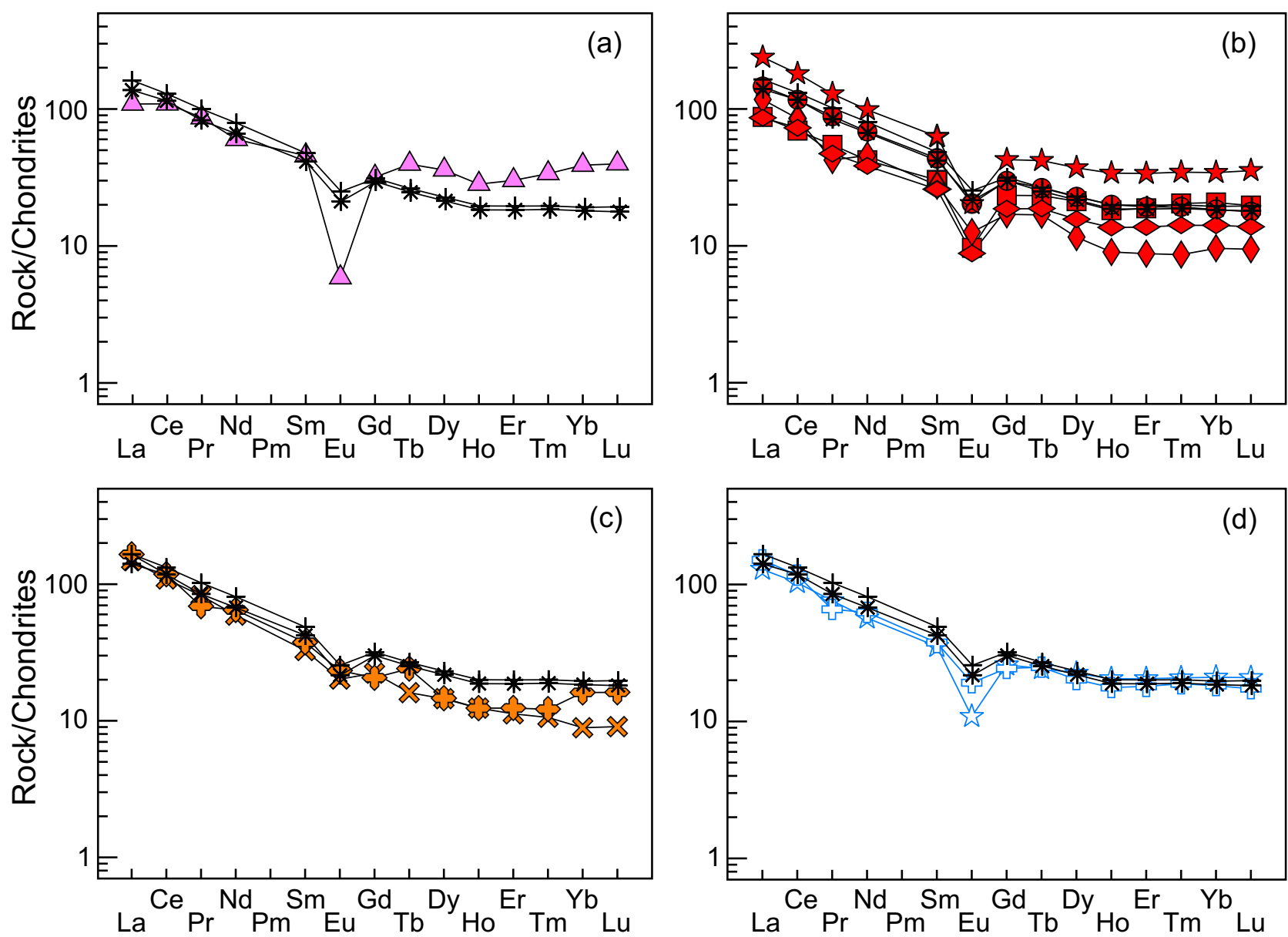

LATE DEVONIAN

$\triangle$ Burnthill Granite

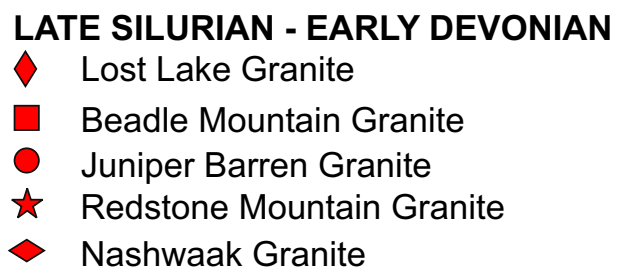

Figure 14. Averaged chondrite-normalized rare-earth-element (REE) profiles of granites and granodiorites from the central part of the Central plutonic belt: (a) Burnthill Granite; (b) late Silurian-Early Devonian granites; (c) late SilurianEarly Devonian granodiorites; and (d) Middle Ordovician granites. In each case, the granite pattern compares well with REE profiles for sedimentary rocks from the Miramichi Group and paragneiss from the Trousers Lake Metamorphic Suite (R. Wilson, unpublished data). Normalizing factors are from Sun and McDonough (1989).

plutonic and volcanic rocks (Whalen 1993; Wilson et al. 2005; Wilson and Kamo 2008, 2012; this study) and eastward extrapolation of successive Devonian positions of the Acadian deformation front (Bradley et al. 2000). Hence, as pointed out by van Staal et al. (2009), Acadian magmatism is more closely associated with crustal shortening than with regional extension or lithospheric delamination. The van Staal et al. (2009) model proposes that asthenospheric "pockets" inherited from Salinic backarc extension and slab break-off became trapped above the Acadian (Avalonian) flat slab; dehydration of the Acadian slab and fluid fluxing of the mantle pockets then generated partial melts having mixed arc and within-plate signatures, and may account for the mantle-derived component of Ganderian granitoid 

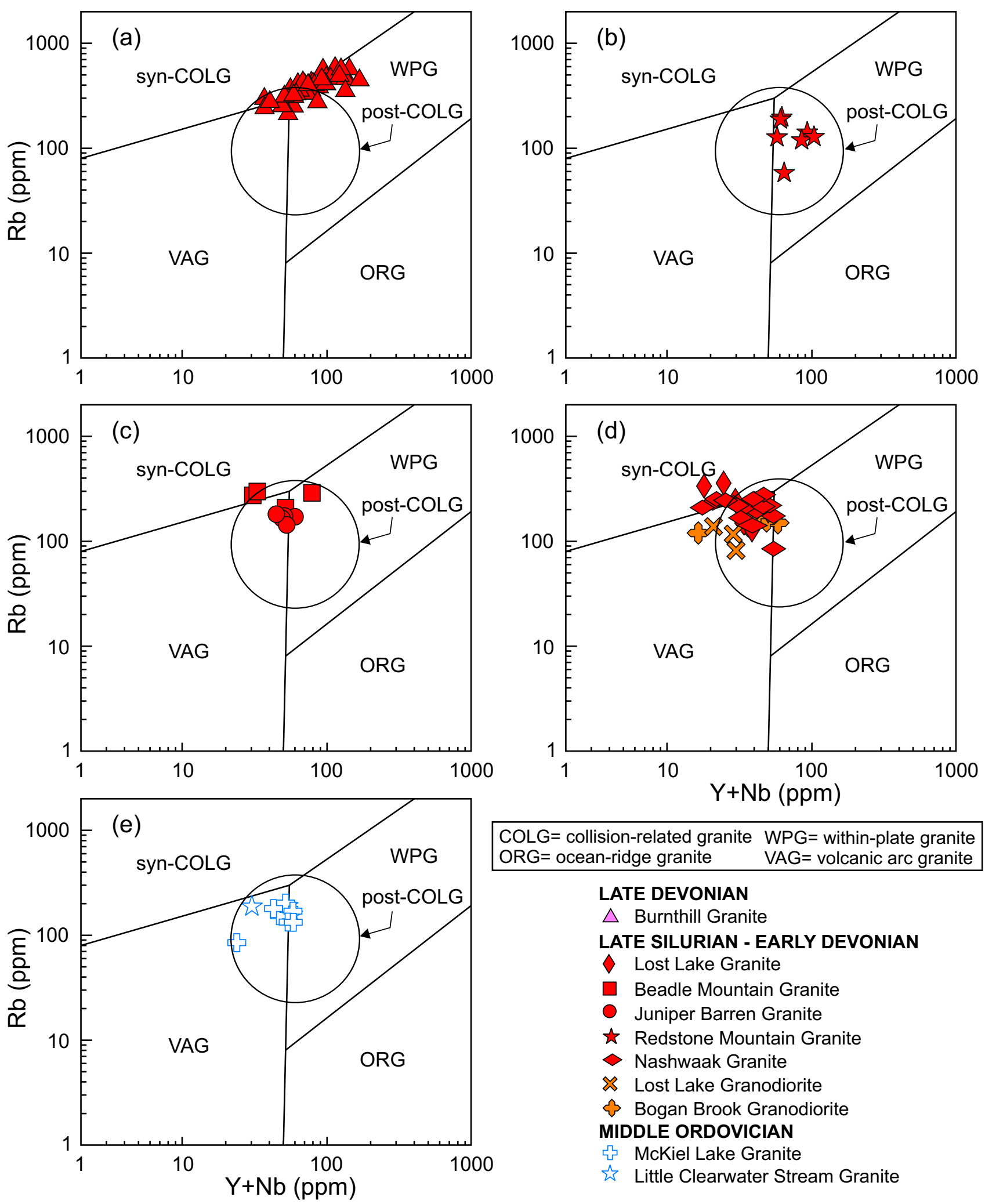

COLG $=$ collision-related granite WPG = within-plate granite $\mathrm{ORG}=$ ocean-ridge granite $\quad \mathrm{VAG}=$ volcanic arc granite

LATE DEVONIAN

$\triangle$ Burnthill Granite

\section{LATE SILURIAN - EARLY DEVONIAN}

$\diamond$ Lost Lake Granite

$\square$ Beadle Mountain Granite

- Juniper Barren Granite

Redstone Mountain Granite

$\diamond$ Nashwaak Granite

Lost Lake Granodiorite

\& Bogan Brook Granodiorite

MIDDLE ORDOVICIAN

凸 McKiel Lake Granite

is Little Clearwater Stream Granite

Figure 15. Rb vs. $\mathrm{Y}+\mathrm{Nb}$ tectonic discrimination diagram (Pearce et al. 1984), including the post-collision granite field of Pearce (1996), applied to granites and granodiorites from the central part of the Central plutonic belt. (a) Burnthill Granite; (b) Redstone Mountain Granite; (c) Beadle Mountain and Juniper Barren granites; (d) Nashwaak and Lost Lake granites, and Bogan Brook and Lost Lake granodiorites; (e) McKiel Lake and Little Clearwater Brook (Ordovician) granites. 


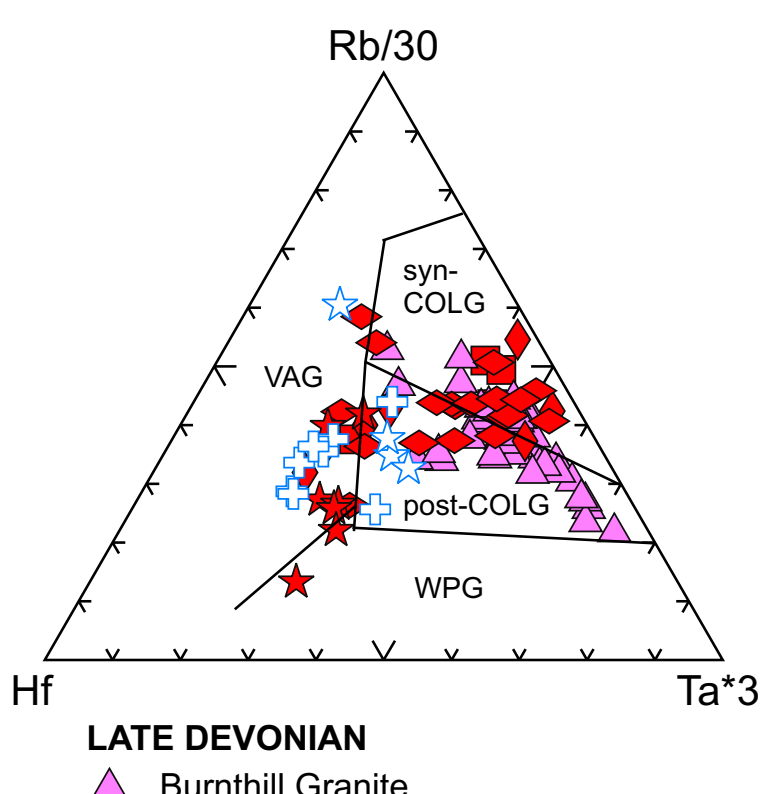

\section{LATE SILURIAN - EARLY DEVONIAN}

$\checkmark$ Lost Lake Granite

$\square$ Beadle Mountain Granite

- Juniper Barren Granite

\. Redstone Mountain Granite

Nashwaak Granite

MIDDLE ORDOVICIAN

ß McKiel Lake Granite

is Little Clearwater Stream Granite

Figure 16. Hf-Rb-Ta tectonic discrimination diagram with fields defined by Harris et al. (1986) for granites from the central part of the Central plutonic belt. VAG: volcanic arc granite; WPG: within-plate granite; syn-COLG, postCOLG: syn- and post-collision granites.

plutons inferred by Kerr et al. (1995), Whalen et al. (1996), and Schofield and D'Lemos (2000). However, granitoid rocks from the study area do not exhibit the high $(\mathrm{La} / \mathrm{Yb})_{\mathrm{CN}}$ values that van Staal et al. (2009) reported for many Devonian plutonic rocks from Gaspé and New Brunswick (their figure 19) and cited as characteristic of Andean flat-slab subduction. Finally, the trapped asthenospheric mantle probably ponded at the base of the crust, unable to ascend because the orogen was under compression, and provided the heat source for large-scale crustal melting that generated the bulk of granitic magma in the Central plutonic belt.

\section{ECONOMIC POTENTIAL}

Economic concentrations of Sn, W, Mo, Sb, Be, etc. are normally associated with highly evolved intrusive phases representing the late-stage, fluid- and incompatible elementenriched apical zones of large magma chambers. Strongly differentiated granites are characterized by elevated $\mathrm{Rb}$ at the expense of $\mathrm{Ba}$ and $\mathrm{Sr}$ (e.g., see Fig. 11a), so that $\mathrm{Rb} /$ $\mathrm{Ba}$ and $\mathrm{Rb} / \mathrm{Sr}$ ratios have been used as estimators of the Sn, W, or Mo-bearing potential of granitic rocks (Tauson and Kozlov 1973; Neiva 1984; Ng et al. 2015). Ternary diagrams illustrating relative abundances of $\mathrm{Ba}, \mathrm{Rb}$, and $\mathrm{Sr}$ are therefore useful in identifying the most fractionated granites, which are normally those that carry the greatest $\mathrm{Sn}$ endowment (Fig. 18). As pointed out by Lehmann (1987), the "geochemical heritage" of Sn-mineralized granites can be as little as 5-10 ppm Sn; in view of this, samples containing greater than $10 \mathrm{ppm} \mathrm{Sn}$ are regarded as Sn-enriched and have been highlighted on Figure 18. Although most of these samples plot in the "strongly differentiated granite" field of El Bouseily and El Sokkary (1975) and Neiva (1984) (Fig. 18), a few Sn-enriched granites lie outside that field, and conversely, some samples containing $<10 \mathrm{ppm} \mathrm{Sn}$ are included within it. Hence, the diagram is not an infallible method of identifying Sn-mineralized granite, but it does confirm the highly evolved character of several of the plutons in the study area.

Another measure of granite evolution and metal-bearing potential that has been shown to be applicable in some areas (e.g., Chatterjee and Muecke 1982) is the ratio of Th to U and how it varies with increasing magmatic differentiation. Plots of $\mathrm{Th} / \mathrm{U}$ vs. $\mathrm{Mg} \#$ and $\mathrm{Th} / \mathrm{U}$ vs. $\mathrm{SiO}_{2}$ (Fig. 19) demonstrate that in many of the granites in the Central plutonic belt, $\mathrm{Th} / \mathrm{U}$ is directly correlated with $\mathrm{Mg \#}$ and inversely correlated with $\mathrm{SiO}_{2}$; i.e., lower $\mathrm{Th} / \mathrm{U}$ is associated with increasing degrees of granite evolution. Exceptions are the Redstone Mountain Granite, which has a narrow range of Th/U (Figs. 19d, 19h) that is unaffected by variation in $\mathrm{Mg} \#$ or $\mathrm{SiO}_{2}$, and some samples of the Nashwaak Granite that appear to constitute a separate population ("Nashwaak group 2"; Figs. 19d, 19h). Similarly, all Silurian-Devonian granites except for the Redstone Mountain and group 2 of the Nashwaak population consistently illustrate an increase in Sn with decreasing $\mathrm{Th} / \mathrm{U}$ (Fig. 20) (Th/U is employed as an index of granite evolution because the Burnthill and Nashwaak granites show poor correlation between $\mathrm{Sn}$ and $\mathrm{Mg} \#$ and between $\mathrm{Sn}$ and $\mathrm{SiO}_{2}$ ).

Compared to average values for Upper Continental Crust (Wedepohl 1995; Rudnick and Gao 2003), granites and granodiorites from the study area, and especially the Silurian and Devonian granites, are enriched in Be, Cs, $\mathrm{P}, \mathrm{Rb}, \mathrm{Sn}, \mathrm{Th}$, $\mathrm{U}$ and $\mathrm{W}$, and depleted in $\mathrm{Ba}, \mathrm{Sc}, \mathrm{Sr}, \mathrm{V}$, and Zr. As shown by numerous workers, highly-evolved, $\mathrm{Sn}$-specialized granites typically exhibit these enrichments and depletions, along with elevated abundances of F, Li, Nb, and Ta (Olade 1980; Chatterjee and Muecke 1982; Edén 1991; Förster et al. 1999). 

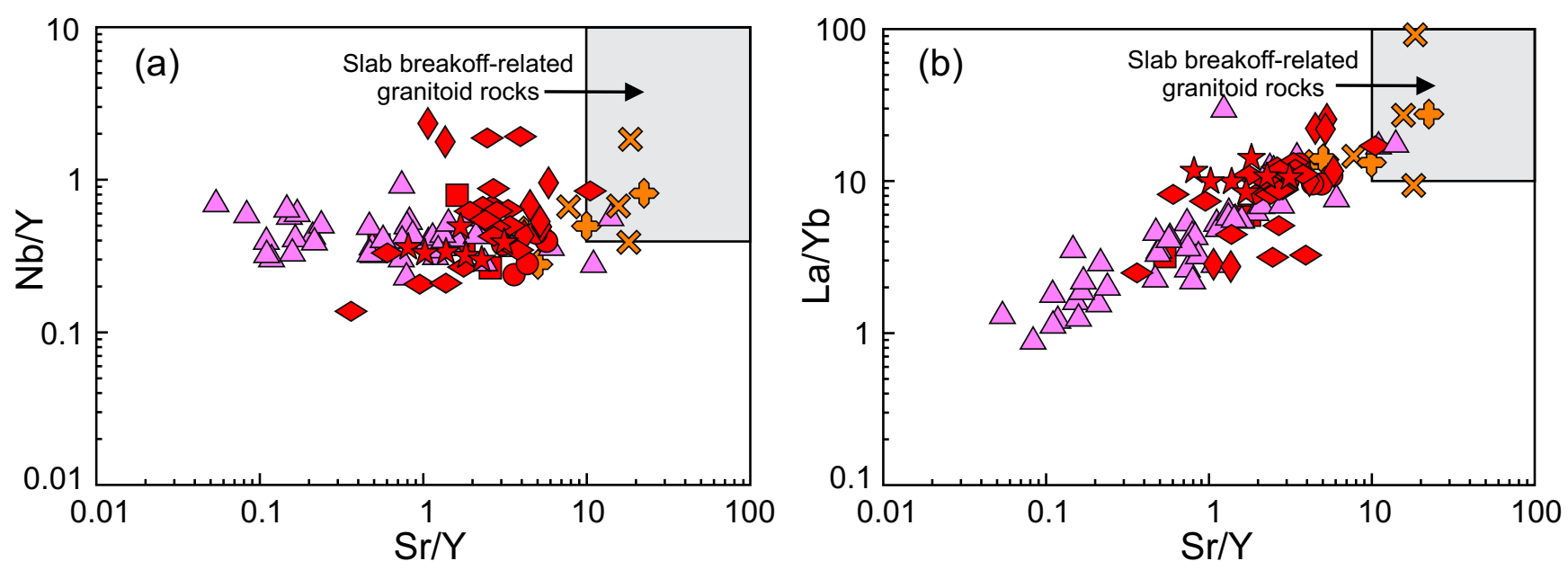

\section{LATE DEVONIAN}

$\triangle$ Burnthill Granite

\section{LATE SILURIAN - EARLY DEVONIAN}

$\diamond$ Lost Lake Granite

Beadle Mountain Granite

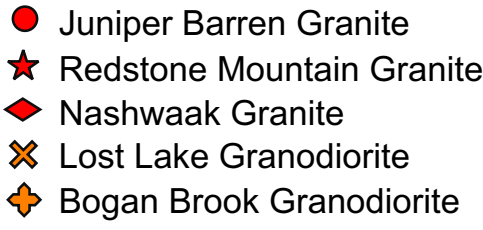

Figure 17. (a) $\mathrm{Nb} / \mathrm{Y}$ vs. $\mathrm{Sr} / \mathrm{Y}$ and (b) $\mathrm{La} / \mathrm{Yb}$ vs. $\mathrm{Sr} / \mathrm{Y}$ diagrams for granites and granodiorites from the central part of the Central plutonic belt. The shaded area is the field of slab-breakoff-related granitoid rocks from Hildebrand and Whalen (2014).

In most cases, some of which are illustrated in Figures 21 and 22 , these trends are evident in granites from the study area. For example, the $\mathrm{Th} / \mathrm{U}$ index of granite evolution is negatively correlated with $\mathrm{Rb}$ and Cs (Fig. 21) and positively correlated with $\mathrm{Ba}$ and $\mathrm{La}$ (Fig. 22). The Nashwaak Granite data again suggest the presence of two populations; for example, group 1 shows a decrease in $\mathrm{Ba}$ and $\mathrm{La}$ with decreasing $\mathrm{Th} / \mathrm{U}$, whereas group 2 forms an antithetic trend (Figs. 22d, 22h).

All plutons from the study area contain average $\mathrm{Sn}$ abundances in excess of the upper continental crustal average of 2.1-2.5 ppm (Wedepohl 1995; Rudnick and Gao 2003) (Table 4 and Fig. 20). The highest average values are present in the Burnthill, Nashwaak, Lost Lake, and Beadle Mountain granites, accompanied by maximum abundances of $31,23,17.5$, and $13 \mathrm{ppm}$ Sn, respectively. Although there is a wide range in the average Sn content of granites associated with tin deposits, the latter figures compare well with those reported for Sn-specialized granites in various "tin belts" world-wide, e.g., Malaysia ( 7-40 ppm; Ishihara and Terashima 1974; Ng et al. 2015), Thailand (7.7-20.0 ppm; Ishihara et al. 1980), Bolivia ( 7-29 ppm; Lehmann et al. 1990), Nigeria ( $22 \mathrm{ppm}$; Olade 1980), and Nova Scotia ( 50 ppm; Chatterjee et al. 1983). Furthermore, most of the New Brunswick plutons are poorly exposed, and have not been sampled systematically; highly evolved phases or cupolas containing greater enrichment in Sn (or
W or Mo) may therefore locally underlie the surficial cover.

The Burnthill Granite (and cogenetic plutons east of the area shown on Figure 1) is associated with exo- and endogranitic W, Mo, Sn, and Be mineralization (Fig. 1) and hosts the greatest average abundances of $\mathrm{Sn}, \mathrm{W}, \mathrm{Be}, \mathrm{F}, \mathrm{Cs}$, Th, and U (Table 4). Almost all samples of Burnthill Granite contain $\mathrm{Sn}$ in excess of 5 ppm (Fig. 20a); in addition, about $30 \%$ of Burnthill samples contain greater than 5 ppm W, up to a maximum of $145 \mathrm{ppm}$. The Lost Lake Granite contains up to $17.5 \mathrm{ppm} \mathrm{Sn,} 24.7 \mathrm{ppm} \mathrm{W}$, and $16 \mathrm{ppm} \mathrm{Be}$, whereas the Beadle Mountain Granite contains up to $13 \mathrm{ppm}$ Sn, $3.7 \mathrm{ppm} \mathrm{W}$, and 4 ppm Mo (Table 4). W-Mo mineralization at the Sisson deposit is located near the contact with the Nashwaak Granite (Fyffe and Thorne 2010; McClenaghan et al. 2014); however, an actual genetic link with the Nashwaak Granite is doubtful, given that recent Re-Os (molybdenite) dating of Sisson mineralization has yielded an age of ca. $378 \mathrm{Ma}$ (Zhang 2015), consistent with an ${ }^{40} \mathrm{Ar} /{ }^{39} \mathrm{Ar}$ age of $379 \mathrm{Ma}$ on the host Howard Peak Granodiorite (Taylor et al. 1987). Nevertheless, the Nashwaak Granite features the second-highest average $\mathrm{Sn}$ abundance (10.7 ppm), ranging to a maximum of $23 \mathrm{ppm} \mathrm{Sn}$, along with 5.3 ppm W and $10 \mathrm{ppm}$ Be. Most of the samples containing elevated Sn are located in the northern part of the pluton, between McKiel Brook and McKiel Lake (Fig. 1), where the biotite - muscovite phase of the granite is predominant. 


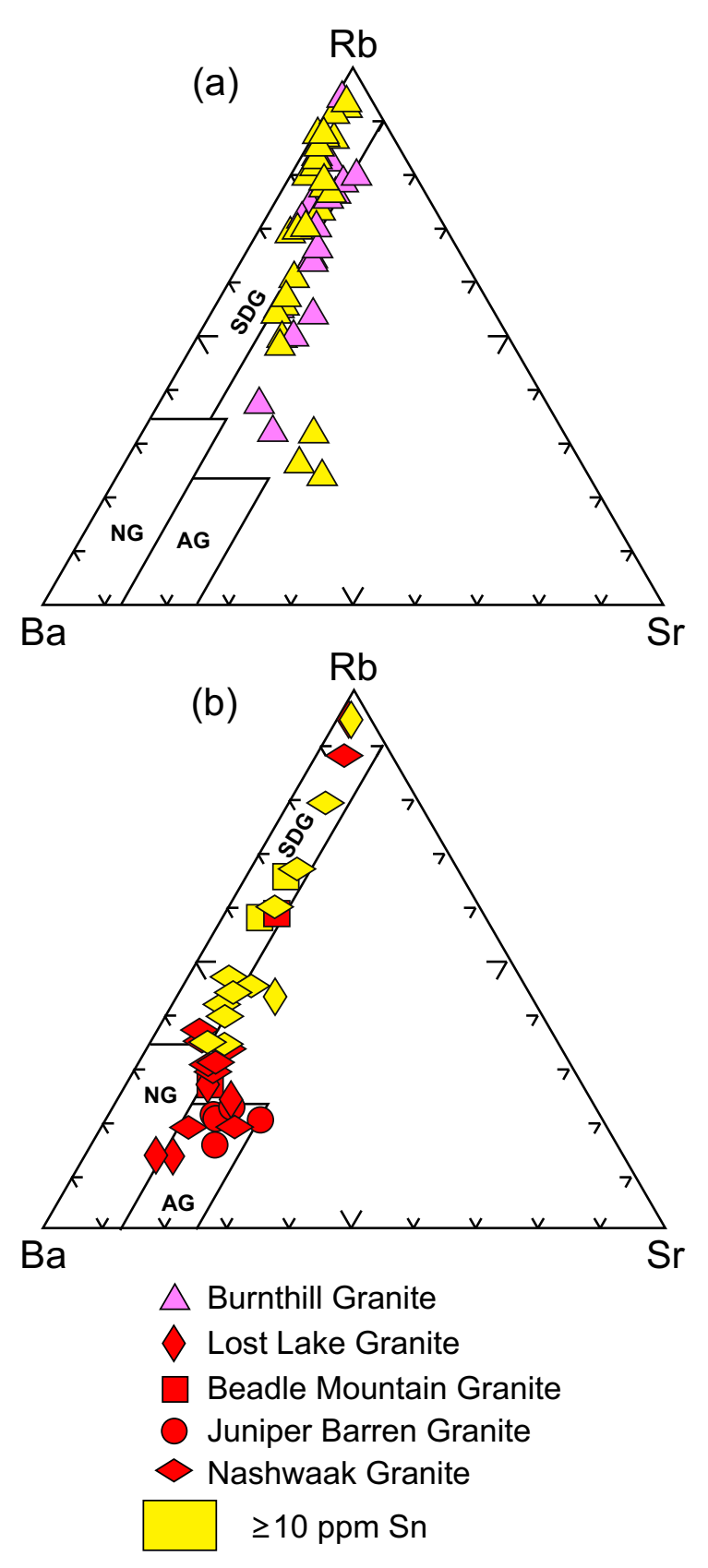

Figure 18. Ba-Rb-Sr ternary diagram for (a) Burnthill Granite, and (b) late Silurian-Early Devonian granites from the central part of the Central plutonic belt. Fields are defined by El Bouseily and El Sokkary (1975): SDG = strongly differentiated granite; $\mathrm{NG}=$ normal granite; $\mathrm{AG}=$ "anomalous" granite (affected by metasomatic processes). Unit symbols shown in yellow contain elevated abundances of $\mathrm{Sn}$; the "threshold" value is arbitrarily defined herein as $10 \mathrm{ppm}$.
However, there is no correlation between this Sn-enriched cluster and one of the two populations suggested by the sample distributions in Figures 19d, 19h, 22d, and 22h.

An isolated sample of granite (TD-11-3; Fig. 1) featuring anomalous concentrations of several elements of economic interest is located adjacent to the Catamaran Brook Fault, where it lies within a small stock thought to be related to the Redstone Mountain Granite about $4 \mathrm{~km}$ to the north (Crouse 1978; Smith and Fyffe 2006b). This

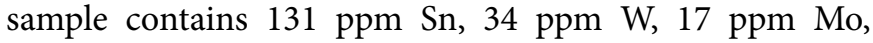
$\sim 10 \mathrm{ppm} \mathrm{Cs}, 115 \mathrm{ppm} \mathrm{Cu}, \sim 32 \mathrm{ppm} \mathrm{Bi}, 35 \mathrm{ppm} \mathrm{As}, 50$ ppm Th, and $\sim 25 \mathrm{ppm} \mathrm{U}$ (Appendix B). However, it is not known whether this mineralization is a magmatic deposit related to a granite cupola, or sourced from mineralbearing fluids associated with the Catamaran Brook Fault.

\section{SUMMARY}

Plutonic rocks in the central part of the Central plutonic belt can be divided into three groups based on age of emplacement/crystallization: (1) late Early to Middle Ordovician (Little Clearwater Brook and McKiel Lake granites); (2) late Silurian to Early Devonian (Lost Lake, Beadle Mountain, Juniper Barren, Nashwaak and Redstone Mountain granites, and the Bogan Brook and Lost Lake granodiorites); and (3) Late Devonian (Burnthill Granite). CA-ID-TIMS U-Pb (zircon) dating yields a late Early to Middle Ordovician age of $467 \pm 7$ Ma for the McKiel Lake Granite; late Silurian ages of $423.2 \pm 3.2 \mathrm{Ma}$ and $420.7+1.8$ /2.0 Ma for the Bogan Brook Granodiorite and Nashwaak Granite, respectively; a $419 \pm 0.5 \mathrm{Ma}$ age that straddles the Silurian-Devonian boundary for the Redstone Mountain Granite; Early Devonian ages of $416.1 \pm 0.5 \mathrm{Ma}, 415.8 \pm 0.3$ $\mathrm{Ma}$, and $409.7 \pm 0.5 \mathrm{Ma}$ for the Beadle Mountain, Juniper Barren, and Lost Lake granites, respectively; and a Late Devonian age of $380.6 \pm 0.3 \mathrm{Ma}$ for the Burnthill Granite.

Plutons of all ages show marked chemical similarities on major and trace element variation diagrams. All are predominantly calc-alkalic, weakly to moderately peraluminous, S-type granites, although the Burnthill Granite and Redstone Mountain Granite display mixed S- and I-type characteristics. Except for the less evolved Juniper Barren Granite, Silurian-Devonian plutons in the study area are mainly silica-rich, evolved granites with average Mg\#s ranging from 18 to 28 (Table 3). They display mixed arc and within-plate affiliation, but tend to cluster in syn- to post-orogenic fields on tectonic discrimination diagrams (Figs. 7, 15, 16); Ordovician granites also display mixed continental arc and within-plate affinities, probably because they were associated with extension of the Popelogan arc and incipient (Tetagouche) backarc rifting in a lower crustal region "contaminated" by prior subduction. The unique geochemical characteristics 

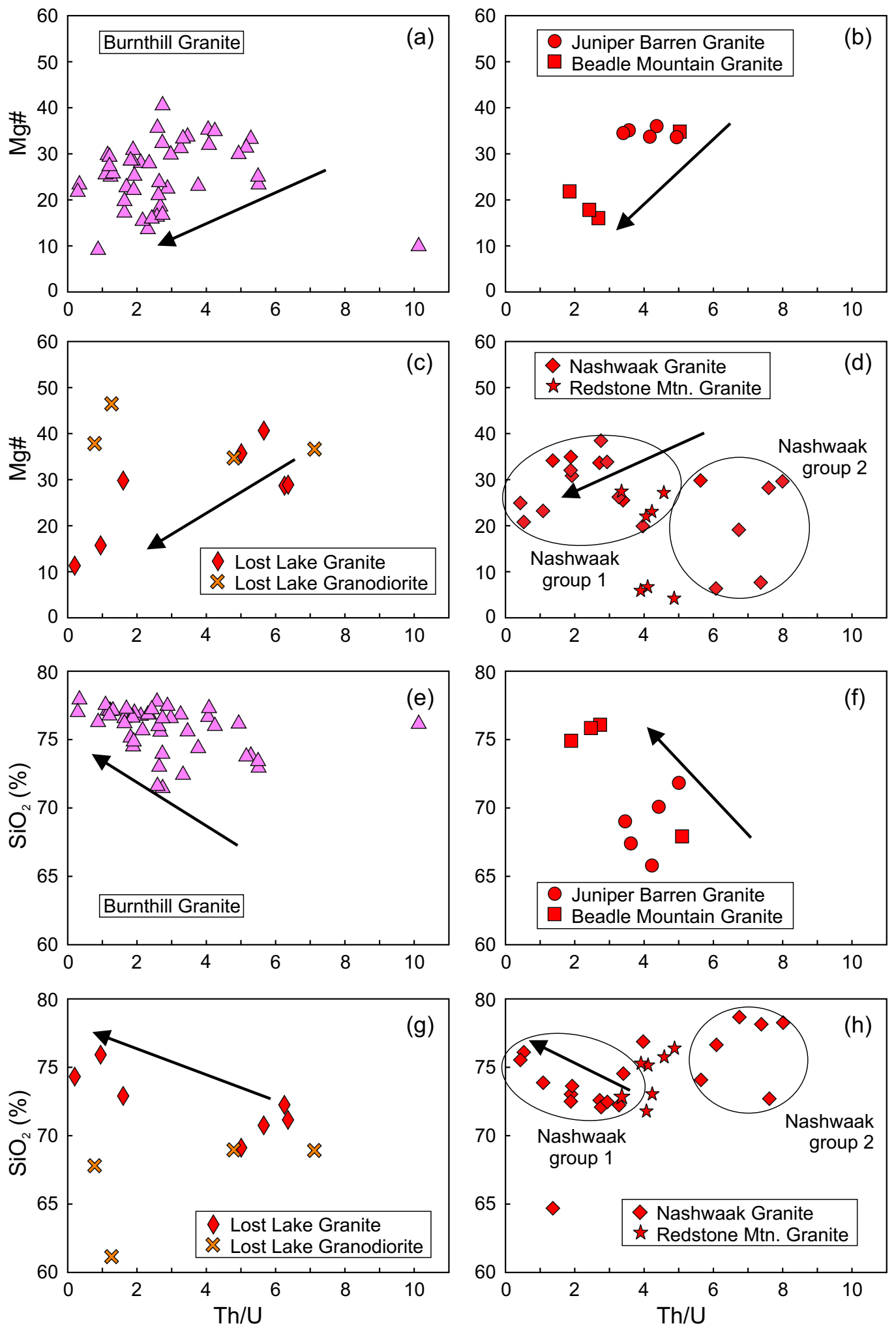

Figure 19. (a) to (d) $\mathrm{Mg \#}$ vs. $\mathrm{Th} / \mathrm{U}$ variation diagrams; and (e) to (h) $\mathrm{SiO}_{2}$ vs. $\mathrm{Th} / \mathrm{U}$ variation diagrams for granites and granodiorites from the central part of the Central plutonic belt. Arrows indicate increasing degrees of granite evolution. $\mathrm{Mg} \#=$ mol. $100 \times \mathrm{MgO} /\left(\right.$ mol. $\left.\mathrm{MgO}+\mathrm{FeO}^{\mathrm{t}}\right)$. 

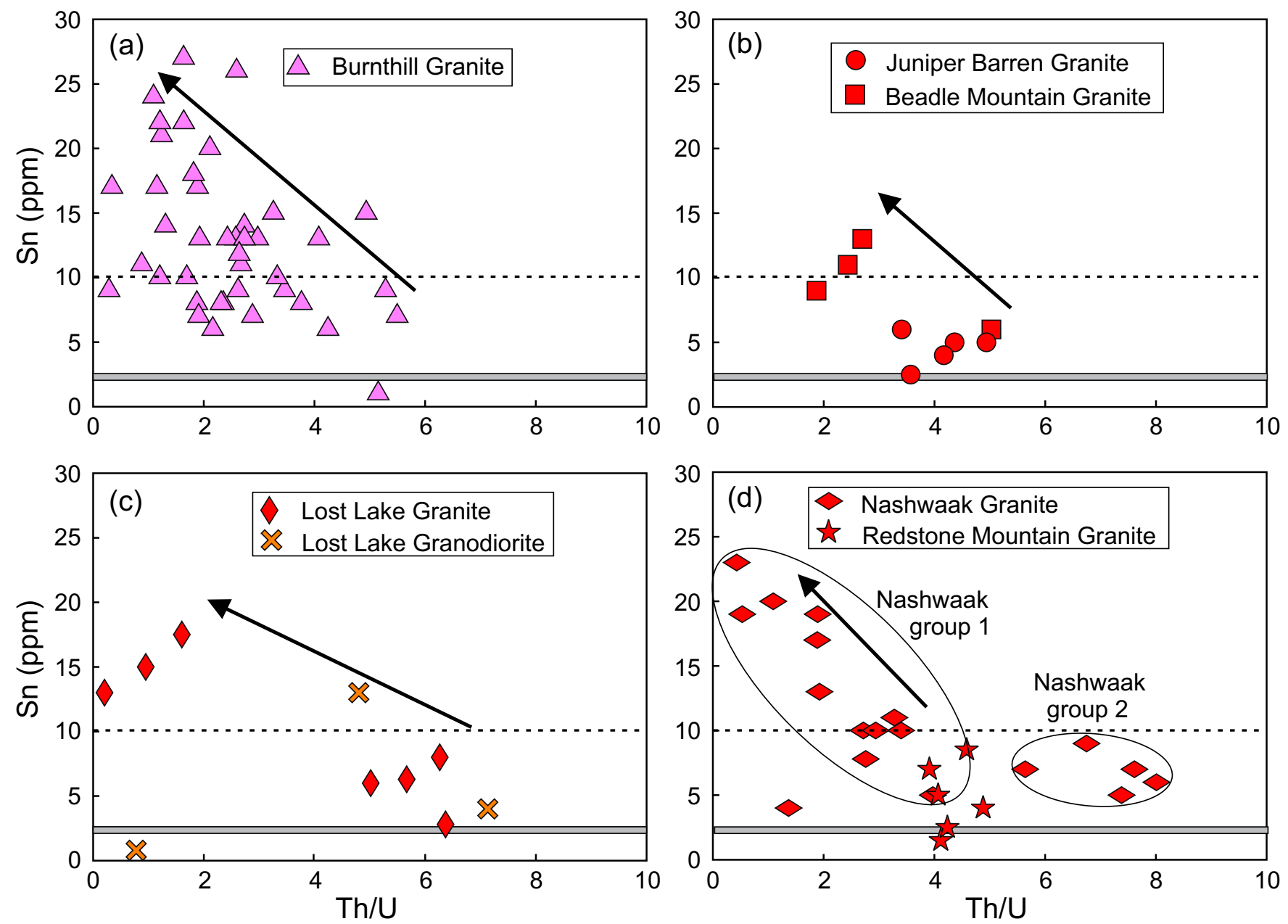

Figure 20. Sn vs. Th/U variation diagrams for granites and granodiorites from the central part of the Central plutonic belt. The grey bar shows the average Sn abundance for upper continental crust (Wedepohl 1995; Rudnick and Gao 2003), and the heavy dashed line is drawn at the arbitrarily defined "threshold" level of $10 \mathrm{ppm}$, as given in Figure 18. Arrows indicate increasing degrees of granite evolution.

of the Burnthill Granite have been interpreted as being related to post-melting petrogenetic processes, e.g., a high degree of crystal fractionation, rather than to the source (Whalen 1993); Sn and W deposits and occurrences are attributed to hydrothermal processes such as aqueous phase saturation and fluid separation (MacLellan and Taylor 1989). In contrast, the Redstone Mountain Granite is chemically more typical of within-plate magmatism, and forms a bimodal association with spatially-related mafic intrusive rocks. It is also interpreted as the subvolcanic source of coeval felsic volcanic rocks of the nearby Costigan Mountain Formation (Walker and Clark 2012).

Lithogeochemical data such as trace element ratios and REE profiles, as well as $\mathrm{Nd}, \mathrm{O}$, and $\mathrm{Pb}$ isotope systematics (Whalen et al. 1996, 1998) show that Ordovician and Silurian-Devonian granites were derived from geochemically and isotopically similar protoliths. The voluminous magmas responsible for late Silurian-Early Devonian plutonism were probably generated as a result of crustal thickening following the ca. $430 \mathrm{Ma}$ collision of Ganderia and composite Laurentia, and/or underthrusting of Ganderia's trailing edge by the leading edge of Avalonia, which (a) generated mixed arc and within-plate-type melts above the dehydrating slab, and (b) trapped pockets of asthenospheric mantle against the base of the crust, leading to large-scale crustal melting (van Staal et al. 2009).

All granites in the central part of the Central plutonic belt show at least some enrichment in Sn compared to global average granite, and in several cases contain $S n$ in amounts comparable to tin-productive granites in other parts of the world. The greatest enrichment occurs in the most evolved felsic plutons, i.e., the Burnthill, Lost Lake, Nashwaak, 

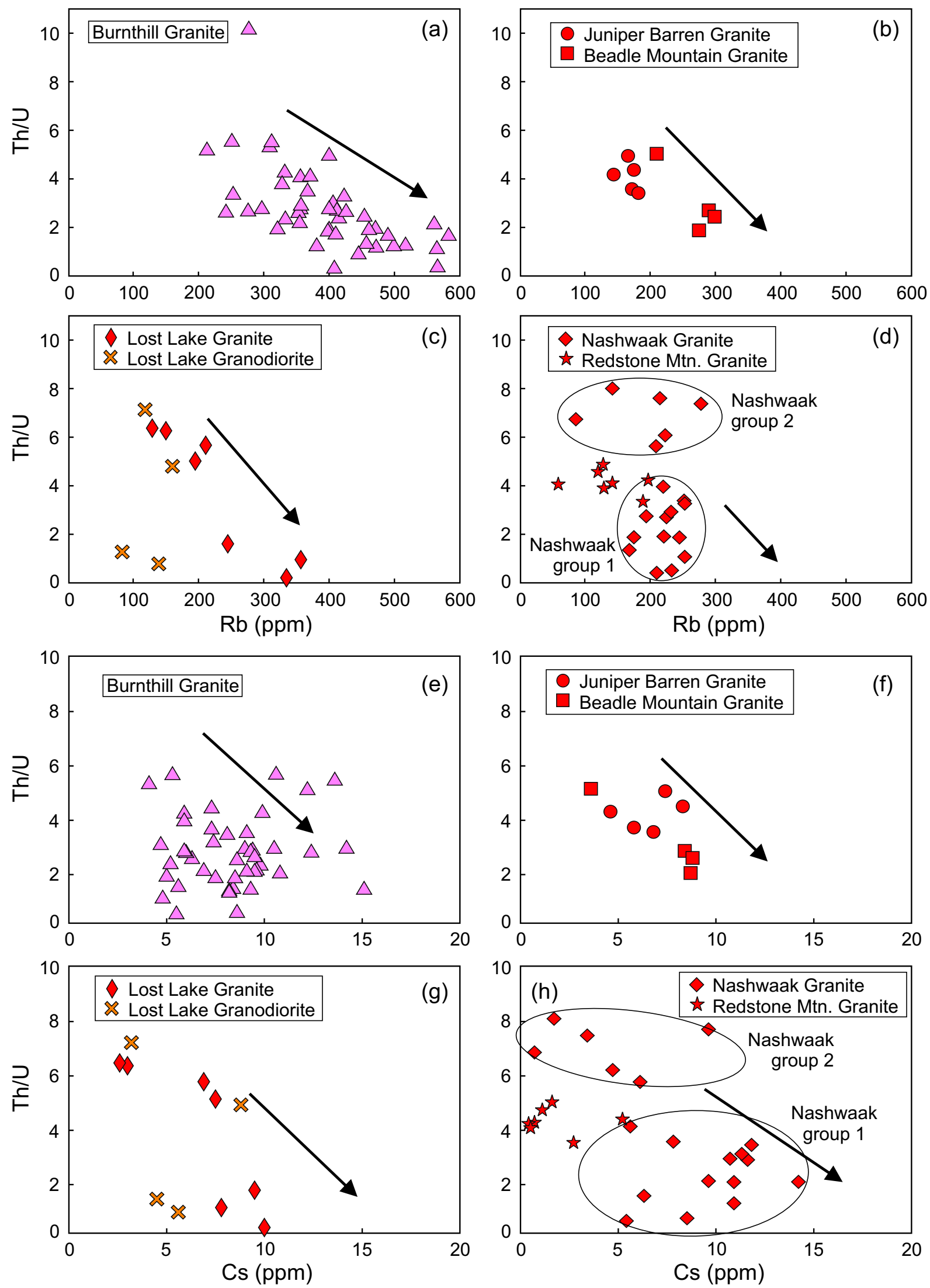

Figure 21. (a) to (d) Th/U vs. $R b$, and (e) to (h) Th/U vs. Cs variation diagrams for granites and granodiorites from the central part of the Central plutonic belt. Arrows indicate increasing degrees of granite evolution. 

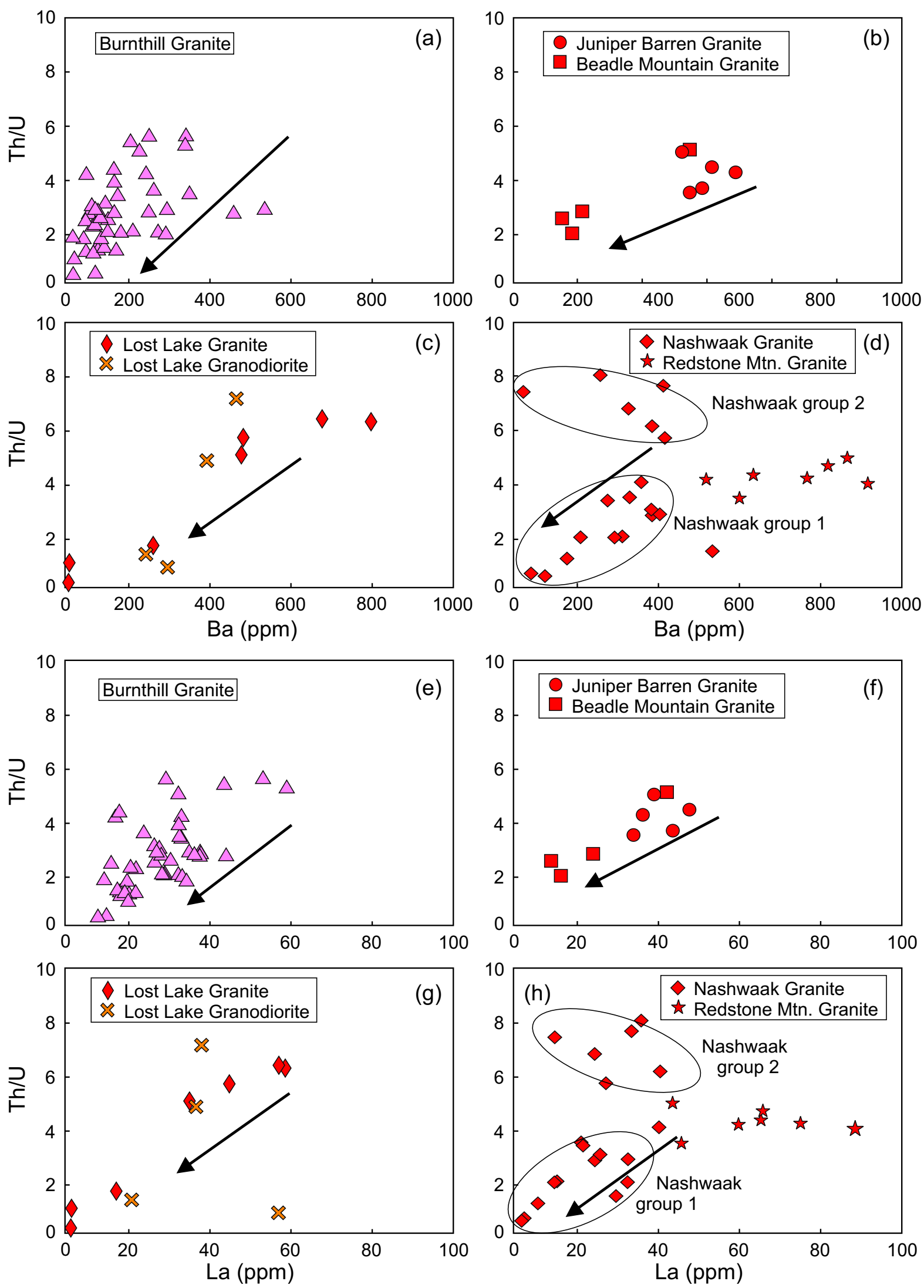

Figure 22. (a) to (d) Th/U vs. Ba, and (e) to (h) Th/U vs. La variation diagrams for granites and granodiorites from the central part of the Central plutonic belt. Arrows indicate increasing degrees of granite evolution. 
Table 4. Mean and range of selected trace elements in granitoid rocks from the central part of the Central plutonic belt, New Brunswick. All values are given in parts per million.

\begin{tabular}{|c|c|c|c|c|c|c|c|c|c|c|}
\hline Unit & Burnthill & $\begin{array}{c}\text { Beadle } \\
\text { Mountain }\end{array}$ & $\begin{array}{l}\text { Juniper } \\
\text { Barren }\end{array}$ & $\begin{array}{l}\text { Lost Lake } \\
\text { Granite }\end{array}$ & Nashwaak & $\begin{array}{l}\text { Redstone } \\
\text { Mountain }\end{array}$ & $\begin{array}{c}\text { Lost Lake } \\
\text { Granodiorite }\end{array}$ & $\begin{array}{l}\text { Bogan } \\
\text { Brook }\end{array}$ & $\begin{array}{c}\text { Little } \\
\text { Clear-water }\end{array}$ & $\begin{array}{l}\text { McKiel } \\
\text { Lake }\end{array}$ \\
\hline $\mathrm{n}$ & 47 & 6 & 6 & 9 & 20 & 11 & 4 & 6 & 4 & 11 \\
\hline $\mathrm{Ba}$ & $\begin{array}{c}134 \\
(19-514)\end{array}$ & $\begin{array}{c}232 \\
(125-454)\end{array}$ & $\begin{array}{c}473 \\
(382-572)\end{array}$ & $\begin{array}{c}359 \\
(9-788)\end{array}$ & $\begin{array}{c}267 \\
(22-511)\end{array}$ & $\begin{array}{c}567 \\
(19-913)\end{array}$ & $\begin{array}{c}320 \\
(208-441)\end{array}$ & $\begin{array}{c}483 \\
(348-533)\end{array}$ & $\begin{array}{c}284 \\
(186-370)\end{array}$ & $\begin{array}{c}439 \\
(277-622)\end{array}$ \\
\hline $\mathrm{Be}$ & $\begin{array}{c}8 \\
(6-12)\end{array}$ & $\begin{array}{c}3 \\
(2-6)\end{array}$ & $\begin{array}{c}4 \\
(3-5)\end{array}$ & $\begin{array}{c}5 \\
(2-16)\end{array}$ & $\begin{array}{c}5 \\
(2-10)\end{array}$ & $\begin{array}{c}4 \\
(2-5)\end{array}$ & $\begin{array}{c}5 \\
(4-7)\end{array}$ & $\begin{array}{c}4 \\
(3-7)\end{array}$ & $\begin{array}{c}3 \\
(1-4)\end{array}$ & $\begin{array}{c}3 \\
(2-6)\end{array}$ \\
\hline Cs & $\begin{array}{c}8.0 \\
(2.3-15.1)\end{array}$ & $\begin{array}{c}7.2 \\
(3.6-9.2)\end{array}$ & $\begin{array}{c}6.6 \\
(4.6-8.3)\end{array}$ & $\begin{array}{c}6.4 \\
(2.6-10.0)\end{array}$ & $\begin{array}{c}8.1 \\
(0.7-14.2)\end{array}$ & $\begin{array}{c}2.2 \\
(0.2-5.2)\end{array}$ & $\begin{array}{c}5.5 \\
(3.2-8.8)\end{array}$ & $\begin{array}{c}8.3 \\
(5.9-11.3)\end{array}$ & $\begin{array}{c}6.3 \\
(3.8-12.4)\end{array}$ & $\begin{array}{c}4.7 \\
(1.1-16.0)\end{array}$ \\
\hline $\mathrm{Cu}$ & $\begin{array}{c}9 \\
(<1-54)\end{array}$ & $\begin{array}{c}7 \\
(1-23)\end{array}$ & $\begin{array}{c}9 \\
(3-17)\end{array}$ & $\begin{array}{c}6 \\
(<1-12)\end{array}$ & $\begin{array}{c}5 \\
(<1-27)\end{array}$ & $\begin{array}{c}13 \\
(1-6)\end{array}$ & $\begin{array}{c}9 \\
(6-11)\end{array}$ & $\begin{array}{c}17 \\
(9-28)\end{array}$ & $\begin{array}{c}5 \\
(2-9)\end{array}$ & $\begin{array}{c}7 \\
(1-32)\end{array}$ \\
\hline $\mathrm{F}^{*}$ & $\begin{array}{c}812 \\
(70-2430)\end{array}$ & na & na & $\begin{array}{c}534 \\
(275-690)\end{array}$ & $\begin{array}{c}561 \\
(365-680)\end{array}$ & $\begin{array}{c}555 \\
(110-740)\end{array}$ & $\begin{array}{c}490 \\
(390-680)\end{array}$ & $\begin{array}{c}678 \\
(610-740)\end{array}$ & na & $\begin{array}{c}681 \\
(360-1100)\end{array}$ \\
\hline Mo & $\begin{array}{c}1.4 \\
(<0.5-4.0)\end{array}$ & $\begin{array}{c}1.5 \\
(<2.0-4.0)\end{array}$ & $\begin{array}{c}\sim 0.9 \\
(<2.0)\end{array}$ & $\begin{array}{c}\sim 0.7 \\
(<2.0)\end{array}$ & $\begin{array}{c}\sim 0.9 \\
(<2.0)\end{array}$ & $\begin{array}{c}\sim 1.0 \\
(<2.0-3.0)\end{array}$ & $\begin{array}{c}\sim 0.4 \\
(<2.0)\end{array}$ & $\begin{array}{c}\sim 1.0 \\
(<0.5-2.0)\end{array}$ & $\begin{array}{c}\sim 1.0 \\
(<2.0)\end{array}$ & $\begin{array}{c}0.7 \\
(<2.0)\end{array}$ \\
\hline $\mathrm{Nb}$ & $\begin{array}{c}25.5 \\
(8.0-52.0)\end{array}$ & $\begin{array}{c}13.1 \\
(8.5-21.6)\end{array}$ & $\begin{array}{c}13.0 \\
(9.9-16.6)\end{array}$ & $\begin{array}{c}14.2 \\
(11.4-15.5)\end{array}$ & $\begin{array}{c}12.0 \\
(5.7-16.4)\end{array}$ & $\begin{array}{c}20.7 \\
(11.3-33.0)\end{array}$ & $\begin{array}{c}12.5 \\
(8.5-16.0)\end{array}$ & $\begin{array}{c}13.6 \\
(7.5-18.7)\end{array}$ & $\begin{array}{c}12.7 \\
(3.5-16.7)\end{array}$ & $\begin{array}{c}13.1 \\
(4.4-22.0)\end{array}$ \\
\hline $\mathrm{Rb}$ & $\begin{array}{c}391 \\
(87-581)\end{array}$ & $\begin{array}{c}250 \\
(209-298)\end{array}$ & $\begin{array}{c}183 \\
(143-266)\end{array}$ & $\begin{array}{c}225 \\
(128-356)\end{array}$ & $\begin{array}{c}212 \\
(85-277)\end{array}$ & $\begin{array}{c}158 \\
(4-196)\end{array}$ & $\begin{array}{c}124 \\
(82-159)\end{array}$ & $\begin{array}{c}144 \\
(120-178)\end{array}$ & $\begin{array}{c}174 \\
(153-192)\end{array}$ & $\begin{array}{c}156 \\
(86-204)\end{array}$ \\
\hline Sn & $\begin{array}{c}12.4 \\
(1.0-31.0)\end{array}$ & $\begin{array}{c}8.3 \\
(5.0-13.0)\end{array}$ & $\begin{array}{c}5.4 \\
(2.5-10.0)\end{array}$ & $\begin{array}{c}9.6 \\
(2.8-17.5)\end{array}$ & $\begin{array}{c}10.7 \\
(<0.5-23.0)\end{array}$ & $\begin{array}{c}5.6 \\
(<0.5-10.0)\end{array}$ & $\begin{array}{c}4.5 \\
(<0.5-13.0)\end{array}$ & $\begin{array}{c}2.9 \\
(<0.5-4.0)\end{array}$ & $\begin{array}{c}3.9 \\
(<1.0-6.0)\end{array}$ & $\begin{array}{c}4.8 \\
(2.0-12.0)\end{array}$ \\
\hline $\mathrm{Sr}$ & $\begin{array}{c}55 \\
(4-334)\end{array}$ & $\begin{array}{c}52 \\
(30-106)\end{array}$ & $\begin{array}{c}149 \\
(77-201)\end{array}$ & $\begin{array}{c}89 \\
(8-147)\end{array}$ & $\begin{array}{c}59 \\
(15-187)\end{array}$ & $\begin{array}{c}100 \\
(56-256)\end{array}$ & $\begin{array}{c}249 \\
(139-396)\end{array}$ & $\begin{array}{c}181 \\
(123-247)\end{array}$ & $\begin{array}{c}46 \\
(26-55)\end{array}$ & $\begin{array}{c}117 \\
(35-231)\end{array}$ \\
\hline Th & $\begin{array}{c}36.2 \\
(8.9-157.0)\end{array}$ & $\begin{array}{c}15.3 \\
(9.2-21.7)\end{array}$ & $\begin{array}{c}16.9 \\
(11.8-20.2)\end{array}$ & $\begin{array}{c}13.3 \\
(2.0-29.8)\end{array}$ & $\begin{array}{c}14.7 \\
(2.3-40.6)\end{array}$ & $\begin{array}{c}25.4 \\
(18.4-27.3)\end{array}$ & $\begin{array}{c}10.5 \\
(3.3-16.4)\end{array}$ & $\begin{array}{c}14.2 \\
(9.8-17.3)\end{array}$ & $\begin{array}{c}18.5 \\
(10.9-23.6)\end{array}$ & $\begin{array}{c}15.6 \\
(9.8-31.5)\end{array}$ \\
\hline $\mathrm{U}$ & $\begin{array}{c}16.3 \\
(4.2-36.0)\end{array}$ & $\begin{array}{c}5.3 \\
(3.5-7.4)\end{array}$ & $\begin{array}{c}4.4 \\
(3.4-5.7)\end{array}$ & $\begin{array}{c}4.3 \\
(2.1-10.7)\end{array}$ & $\begin{array}{c}4.2 \\
(2.4-8.5)\end{array}$ & $\begin{array}{c}7.4 \\
(3.8-6.7)\end{array}$ & $\begin{array}{c}5.1 \\
(2.3-13.1)\end{array}$ & $\begin{array}{c}4.6 \\
(3.1-7.0)\end{array}$ & $\begin{array}{c}4.1 \\
(3.1-4.8)\end{array}$ & $\begin{array}{c}3.1 \\
(1.1-6.8)\end{array}$ \\
\hline W & $\begin{array}{c}9.0 \\
(<0.5-145.0)\end{array}$ & $\begin{array}{c}2.3 \\
(<0.5-3.7)\end{array}$ & $\begin{array}{c}1.1 \\
(<0.5-2.8)\end{array}$ & $\begin{array}{c}3.7 \\
(<0.5-24.7)\end{array}$ & $\begin{array}{c}1.4 \\
(<0.5-5.3)\end{array}$ & $\begin{array}{c}1.0 \\
(<1.0-3.0)\end{array}$ & $\begin{array}{c}0.6 \\
(<0.5-1.0)\end{array}$ & $\begin{array}{c}0.6 \\
(<0.5-1.3)\end{array}$ & $\begin{array}{c}1.1 \\
(<0.5-1.5)\end{array}$ & $\begin{array}{c}1.5 \\
(<0.5-13.3)\end{array}$ \\
\hline $\mathrm{Zr}$ & $\begin{array}{c}131 \\
(43-1222)\end{array}$ & $\begin{array}{c}116 \\
(46-292)\end{array}$ & $\begin{array}{c}213 \\
(83-323)\end{array}$ & $\begin{array}{c}117 \\
(14-205)\end{array}$ & $\begin{array}{c}94 \\
(15-241)\end{array}$ & $\begin{array}{c}233 \\
(134-352)\end{array}$ & $\begin{array}{c}204 \\
(148-230)\end{array}$ & $\begin{array}{c}205 \\
(111-253)\end{array}$ & $\begin{array}{c}151 \\
(80-186)\end{array}$ & $\begin{array}{c}205 \\
(120-368)\end{array}$ \\
\hline $\mathrm{La}$ & $\begin{array}{c}25.8 \\
(8.5-110.0)\end{array}$ & $\begin{array}{c}20.7 \\
(9.7-39.5)\end{array}$ & $\begin{array}{c}34.5 \\
(20.5-45.3)\end{array}$ & $\begin{array}{c}27.7 \\
(1.6-56.8)\end{array}$ & $\begin{array}{c}20.4 \\
(2.1-37.8)\end{array}$ & $\begin{array}{c}56.5 \\
(38.8-88.1)\end{array}$ & $\begin{array}{c}35.3 \\
(17.2-55.0)\end{array}$ & $\begin{array}{c}39.1 \\
(23.4-49.2)\end{array}$ & $\begin{array}{c}30.5 \\
(12.0-39.6)\end{array}$ & $\begin{array}{c}35.8 \\
(18.5-63.0)\end{array}$ \\
\hline $\mathrm{Ce}$ & $\begin{array}{c}66.7 \\
(24.4-370.0)\end{array}$ & $\begin{array}{c}42.5 \\
(20.2-74.1)\end{array}$ & $\begin{array}{c}71.3 \\
(43.2-84.4)\end{array}$ & $\begin{array}{c}52.1 \\
(3.2-97.5)\end{array}$ & $\begin{array}{c}44.5 \\
(3.5-73.9)\end{array}$ & $\begin{array}{c}110.7 \\
(78.6-156.0)\end{array}$ & $\begin{array}{c}66.8 \\
(36.0-92.5)\end{array}$ & $\begin{array}{c}72.4 \\
(40.4-90.0)\end{array}$ & $\begin{array}{c}63.1 \\
(25.6-82.2)\end{array}$ & $\begin{array}{c}71.5 \\
(40.6-118.0)\end{array}$ \\
\hline
\end{tabular}

* Source: MacLellan et al. (1990) and Whalen (1993); mean and range of values are based on fewer analyses than for other elements.

and Beadle Mountain granites. This specialization in Sn is accompanied by enrichments in elements such as $\mathrm{Rb}$, $\mathrm{Cs}, \mathrm{Be}, \mathrm{W}$, and $\mathrm{P}$, high $\mathrm{Rb} / \mathrm{Sr}$, low $\mathrm{Th} / \mathrm{U}$, and depletions in $\mathrm{Sr}, \mathrm{Ba}, \mathrm{REE}, \mathrm{Sc}$, and $\mathrm{Zr}$, which are considered proxies for potential economic mineralization in other granophile elements such as Mo and W. Anomalous abundances of $\mathrm{W}$ are present in some samples of the Burnthill, Lost Lake,
Nashwaak and even the Ordovician McKiel Lake Granite, although Ordovician plutons, except for the arc-type Gibson and Benton plutons in the Woodstock area (Fig. 1 ), are not known to be associated with mineralization. The Juniper Barren, Lost Lake and Nashwaak granites are, in large part, poorly exposed, and it is possible that mineralized cupolas are present but as yet undetected. The 
data presented herein indicate that thorough and systematic lithogeochemical analyses can provide an effective vector to potential granophile-element mineralization.

\section{ACKNOWLEDGEMENTS}

Field mapping and sample collection in the Central plutonic belt were carried out by S.H. McClenaghan. Kathleen Thorne and Jim Walker are thanked for their reviews of early versions of the manuscript. The paper was greatly improved by comments and suggestions from journal reviewers Joe Whalen and Andy Kerr.

\section{REFERENCES}

Bevier, M.L. and Whalen, J.B. 1990. Tectonic significance of Silurian magmatism in the Canadian Appalachians. Geology, 18, pp. 411-414. http://dx.doi.org/10.1130/00917613(1990)018<0411:TSOSMI>2.3.CO;2

Bradley, D.C., Tucker, R.D., Lux, D.R., Harris, A.G., and McGregor, D.C. 2000. Migration of the Acadian Orogen and foreland basin across the northern Appalachians of Maine and adjacent areas. United States Geological Survey, Professional Paper 1624, 49 p.

Chappell, B.W. and White, A.J.R. 1992. I- and S-type granites in the Lachlan Fold Belt. Transactions of the Royal Society of Edinburgh: Earth Sciences, 83, pp. 1-26. http://dx.doi. org/10.1017/S0263593300007720

Chatterjee, A.K. and Muecke, G.K. 1982. Geochemistry and distribution of uranium and thorium in the granitoid rocks of the South Mountain Batholith, Nova Scotia: Some genetic and exploration implications. In Uranium in Granites. Edited by Y.T. Maurice. Geological Survey of Canada, Paper 81-23, pp. 11-17.

Chatterjee, A.K., Strong, D.F., and Muecke, G.K. 1983. A multivariate approach to geochemical distinction between tin-specialized and uranium-specialized granites of southern Nova Scotia. Canadian Journal of Earth Sciences, 20, pp. 420-430. http://dx.doi.org/10.1139/e83040

Crouse, G.W. 1978. Geology of head of Clearwater Brook, map area K13. New Brunswick Department of Natural Resources, Mineral Resources Branch, Map Report 771, $16 \mathrm{p}$.

Crouse, G.W. 1981a. Geology of parts of Burnthill, Clearwater and McKiel brooks, mapareas K14, K15, K16 (Parts of 21J/15 and $21 \mathrm{~J} / 10$ ). New Brunswick Department of Natural Resources, Mineral Resources, Map Report $815,46 \mathrm{p}$.

Crouse, G.W. 1981b. Geology of Napadogan and Miramichi lakes (maparea K17) and Napadogan, Rocky, McLean, and Ryan brooks (maparea K18) (Part of $21 \mathrm{~J} / 07 \mathrm{~W}$ ). New
Brunswick Department of Natural Resources, Mineral Resources, Map Report 818, 22 p.

Currie, K.L. 1995. Plutonic Rocks. Chapter 8. In Geology of the Appalachian-Caledonian Orogen in Canada and Greenland. Edited by $\mathrm{H}$. Williams. Geological Survey of Canada, Geology of Canada, No. 6, pp. 629-680 (also Geological Society of America, The Geology of North America, vol. F-1). http://dx.doi.org/10.1130/dnag-gna $-\mathrm{f} 1.629$

Davies, J.H. and von Blanckenburg, F. 1995. Slab breakoff: A model of lithosphere detachment and its test in the magmatism and deformation of collisional orogens. Earth and Planetary Science Letters, 129, pp. 85-102. http:// dx.doi.org/10.1016/0012-821X(94)00237-S

Dostal, J., Keppie, J.D., and Wilson, R.A. in press. Nd isotopic and trace element constraints on the source of Silurian-Devonian mafic lavas in the Chaleur Bay Synclinorium of New Brunswick (Canada): Tectonic implications. Tectonophysics. http://dx.doi.org/10.1016/j. tecto.2015.10.002

Edén, P. 1991. A specialized topaz-bearing rapakivi granite and associated mineralized greisen in the Ahvenisto Complex, SE Finland. Bulletin of the Geological Society of Finland, 63, Part 1, pp. 25-40.

El Bouseily, A.M. and El Sokkary, A.A. 1975. The relationship between $\mathrm{Rb}, \mathrm{Ba}$ and $\mathrm{Sr}$ in granitic rocks. Chemical Geology, 16, pp. 207-219. http://dx.doi. org/10.1016/0009-2541(75)90029-7

Förster, H.-J., Tischendorf, G., Trumbull, R.B., and Gottesmann, B. 1999. Late-collisional granites in the Variscan Erzgebirge, Germany. Journal of Petrology, 40, pp. 1613-1645. http://dx.doi.org/10.1093/petroj/40.11.1613

Frost, B.R., Barnes, C.G., Collins, W.J., Arculus, R.J., Ellis, D.J., and Frost, C.D. 2001. A geochemical classification for granitic rocks. Journal of Petrology, 42, pp. 2033-2048. http://dx.doi.org/10.1093/petrology/42.11.2033

Fyffe, L.R. 2001. Stratigraphy and geochemistry of Ordovician volcanic rocks of the Eel River area, westcentral New Brunswick. Atlantic Geology, 37, pp. 81-101. http://dx.doi.org/10.4138/1973

Fyffe, L.R. and Cormier, R.F. 1979. The significance of radiometric ages from the Gulquac Lake area of New Brunswick. Canadian Journal of Earth Sciences, 16, pp. 2046-2052. http://dx.doi.org/10.1139/e79-190

Fyffe, L.R. and Pronk, A.G. 1985. Bedrock and surficial geology-rock and till geochemistry in the Trousers Lake area, Victoria County, New Brunswick. New Brunswick Department of Natural Resources, Mineral Resources Division, Report of Investigation 20, 74 p.

Fyffe, L.R. and Thorne, K.G. (compilers) 2010. Polymetallic deposits of Sisson Brook and Mount Pleasant, New Brunswick, Canada. New Brunswick Department of Natural Resources; Lands, Minerals and Petroleum Division, Field Guide No. 3, 68 p. 
Fyffe, L., Barr, S.M., and Bevier, M.L. 1988. Origin and U-Pb geochronology of amphibolite-facies metamorphic rocks, Miramichi Highlands, New Brunswick. Canadian Journal of Earth Sciences, 25, pp. 1674-1686. http://dx.doi. org/10.1139/e88-158

Gerstenberger, H. and Haase, G. 1997. A highly effective emitter substance for mass spectrometric $\mathrm{Pb}$ isotope ratio determinations. Chemical Geology, 136, pp. 309-312. http://dx.doi.org/10.1016/S0009-2541(96)00033-2

Harris, N.B.W., Pearce, J.A., and Tindle, A.G. 1986. Geochemical characterization of collision-zone magmatism. In Collision Tectonics. Edited by M.P. Coward and A.C. Ries. Geological Society of London, Special Publication 19, pp. 67-81.

Hildebrand, R.S. and Whalen, J.B. 2014. Arc and slab-failure magmatism in Cordilleran batholiths II -The Cretaceous Peninsular Ranges batholith of southern and Baja California. Geoscience Canada, 41, pp. 399-458. http:// dx.doi.org/10.12789/geocanj.2014.41.059

Hughes, C.J. 1973. Spilites, keratophyres, and the igneous spectrum. Geological Magazine, 109, pp. 513-527. http:// dx.doi.org/10.1017/S0016756800042795

Irrinki, R.R. 1981. Geology of Rocky, Sisters and Clearwater BrooksTodd Mountain region, map areas L14, L15 and L16, New Brunswick. New Brunswick Department of Natural Resources, Mineral Resources, Map Report 817, $30 \mathrm{p}$.

Ishihara, S. and Terashima, S. 1974. Tin contents of granitic rocks in Japan and its environs. In Metallization Associated with Acid Magmatism. Edited by M. Steinprok, L. Burnol and G. Tischendorf. Geological Survey, Prague, 3, pp. 227-234.

Ishihara, S., Sawata, H., Shibata, K., Terashima, S., Arrykul, S., and Sato, K. 1980. Granites and Sn-W deposits of peninsular Thailand. In Granitic Magmatism and Related Mineralization. Edited by S. Ishikara and S. Takenouchi. Mining Geology, Special Issue 8, pp. 223-241.

Jaffey, A.H., Flynn, K.F., Glendenin, L.E., Bentley, W.C., and Essling, A.M. 1971. Precision measurement of half-lives and specific activities of ${ }^{235} \mathrm{U}$ and ${ }^{238} \mathrm{U}$. Physical Review, 4, pp. 889-1906.

Kerr, A., Jenner, G.A., and Fryer, B.J. 1995. Sm-Nd isotopic geochemistry of Precambrian to Paleozoic granitoid suites and the deep-crustal structure of the southeast margin of the Newfoundland Appalachians. Canadian Journal of Earth Sciences, 32, pp. 224-245. http://dx.doi. org/10.1139/e95-019

Krogh, T.E. 1973. A low contamination method for hydrothermal decomposition of zircon and extraction of $\mathrm{U}$ and $\mathrm{Pb}$ for isotopic age determinations. Geochimica et Cosmochimica Acta, 37, pp. 485-494. http://dx.doi. org/10.1016/0016-7037(73)90213-5

Lehmann, B. 1987. Tin granites, geochemical heritage, magmatic differentiation. Geologische Rundschau, 76, pp. 177-185. http://dx.doi.org/10.1007/BF01820581
Lehmann, B., Ishihara, S., Michel, H., Miller, J., Rapela, C., Sanchez, A., Tistl, M., and Winkelmann, L. 1990. The Bolivian tin province and regional tin distribution in the central Andes: A reassessment. Economic Geology, 85, pp. 1044-1058. http://dx.doi.org/10.2113/ gsecongeo.85.5.1044

Ludwig, K.R. 2003. User's manual for Isoplot 3.00: A geochronological toolkit for Microsoft Excel. Berkeley Geochronology Center, Special Publication No. 4, 71 p.

Lutes, G. 1981. Geology of Deersdale-Head of Nashwaak River, map area J17, and upper parts of Nashwaak River McBean and Sisters brooks, map area J18. New Brunswick Department of Natural Resources, Mineral Resources, Map Report 814, $26 \mathrm{p}$.

MacLellan, H.E. and Taylor, R.P. 1989. Geology and geochemistry of the Burnthill Granite and related W-SnMo-F mineral deposits, central New Brunswick. Canadian Journal of Earth Sciences, 26, 499-514. http://dx.doi. org/10.1139/e89-043

MacLellan, H.E., Taylor, R.P., and Gardiner, W.W. 1990. Geology and geochemistry of Middle Devonian Burnthill Brook granites and related tin-tungsten deposits, York and Northumberland counties, New Brunswick. New Brunswick Department of Natural Resources and Energy, Minerals and Energy Division, Mineral Resource Report $4,95 \mathrm{p}$.

Maniar, P.D. and Piccoli, P.M. 1989. Tectonic discrimination of granitoids. Geological Society of America Bulletin, 101, pp. 635-643. http://dx.doi.org/10.1130/00167606(1989) $101<0635:$ TDOG $>2.3 . C O ; 2$

Mattinson, J.M. 2005. Zircon U-Pb chemical abrasion ("CA-TIMS") method: combined annealing and multistep partial dissolution analysis for improved precision and accuracy of zircon ages. Chemical Geology, 220, pp. 47-66. http://dx.doi.org/10.1016/j.chemgeo.2005.03.011

Mattinson, J.M., 2010. Analysis of the relative decay constants of U-235 and U-238 by multi-step CA-TIMS measurements of closed-system natural zircon samples. Chemical Geology, 275, pp. 186-198. http://dx.doi. org/10.1016/j.chemgeo.2010.05.007

McClenaghan, S.H., Thorne, K.G., and Rogers, N. 2014. Granite-related mineralization and alteration in the Acadian Plutonic Belt: Implications for Sn-W-Mo$\mathrm{Cu}$ exploration in central New Brunswick. Geological Association of Canada/ Mineralogical Association of Canada Joint Annual Meeting, Field Trip Guidebook, 74 p.

McNicoll, V., Whalen, J.B., and Stern, R.A. 2003. U-Pb geochronology of Ordovician plutonism, Bathurst Mining Camp, New Brunswick. In Massive Sulfide Deposits of the Bathurst Mining Camp, New Brunswick, and Northern Maine. Edited by W.D. Goodfellow, S.R. McCutcheon and J.M. Peter. Economic Geology Monograph 11, pp. 203-218.

Miyashiro, A. 1974. Volcanic rock series in island arcs and 
active continental margins. American Journal of Science, 274, 321-355. http://dx.doi.org/10.2475/ajs.274.4.321

Murphy, J.B., van Staal, C.R., and Keppie, J.D. 1999. Middle to late Paleozoic Acadian orogeny in the northern Appalachians: A Laramide-style plume-modified orogeny? Geology, 27, pp. 653-656. http://dx.doi. org/10.1130/0091-7613(1999)027<0653:MTLPAO>2.3 . $\mathrm{CO} ; 2$

Neiva, A.M.R. 1984. Geochemistry of tin-bearing granitic rocks. Chemical Geology, 43, pp. 241-256. http://dx.doi. org/10.1016/0009-2541(84)90052-4

Nelson, K.D. 1992. Are crustal thickness variations in old mountain belts like the Appalachians a consequence of lithospheric delamination? Geology, 20, pp. 498-502. http://dx.doi.org/10.1130/0091-7613(1992)020<0498:AC TVIO $>2.3 . C O ; 2$

Ng, S.W.-P., Chung, S.-L., Robb, L.J., Searle, M.P., Ghani, A.A., Whitehouse, M.J., Oliver, G.J.H., Sone, M., Gardiner, N.J., and Roselee, M.H. 2015. Petrogenesis of Malaysian granitoids in the Southeast Asian tin belt: Part 1. Geochemical and Sr-Nd isotopic characteristics. Geological Society of America Bulletin, 127, pp. 1209-1237. http://dx.doi.org/10.1130/B31213.1

Olade, M.A. 1980. Geochemical characteristics of tinbearing and tin-barren granites, northern Nigeria. Economic Geology, 75, pp. 71-82. http://dx.doi. org/10.2113/gsecongeo.75.1.71

Pearce, J.A. 1996. Sources and settings of granitic rocks. Episodes, 19, pp. 120-125.

Pearce, J.A., Harris, N.B.W., and Tindle, A.G. 1984. Trace element discrimination diagrams for the tectonic interpretation of granitic rocks. Journal of Petrology, 25, pp. 956-983. http://dx.doi.org/10.1093/petrology/25.4.956

Poole, W.H. 1980. Rb-Sr ages of the "Sugar" Granite and Lost Lake Granite, Miramichi Anticlinorium, Hayesville map area, New Brunswick. In $\mathrm{Rb}-\mathrm{Sr}$ and $\mathrm{U}-\mathrm{Pb}$ Isotopic Age Studies, Current Research, Part C, Geological Survey of Canada, Paper 80-1C, pp. 174-180.

Rogers, N. 2011. TGI-4 intrusion-related mineralization project: Identifying new vectors to hidden mineralization. In Abstracts 2011: Exploration, Mining and Petroleum New Brunswick. Edited by E.A. Smith. New Brunswick Department of Natural Resources; Lands, Minerals and Petroleum Division, Information Circular 2011-1, pp. 50-51.

Rudnick, R.L. and Gao, S. 2003. Composition of the continental crust. In The Crust. volume 3 of Treatise on Geochemistry. Edited by R.L. Rudnick. ElsevierPergamon, Oxford, pp. 1-64. http://dx.doi.org/10.1016/ b0-08-043751-6/03016-4

Ruitenberg, A.A. and Fyffe, L.R. 1982. Mineral deposits associated with granitoid intrusions and related subvolcanic stocks in New Brunswick and their relationship to Appalachian tectonic evolution. Canadian
Institute of Mining and Metallurgy Bulletin, 75, No. 842, pp. 83-97.

Schoene, B., Crowley, J.L., Condon, D.J., Schmitz, M.D., and Bowring, S.A., 2006. Reassessing the uranium decay constants for geochronology using ID-TIMS U-Pb data. Geochimica et Cosmochimica Acta, 70, pp. 426-445. http://dx.doi.org/10.1016/j.gca.2005.09.007

Schofield, D.I. and D'Lemos, R.S. 2000. Granite petrogenesis in the Gander Zone, NE Newfoundland: Mixing of melts from multiple sources and the role of lithospheric delamination. Canadian Journal of Earth Sciences, 37, pp. 535-547. http://dx.doi.org/10.1139/e99-116

Shand, S.J. 1943. Eruptive Rocks: Their Genesis, Composition, Classification, and Their Relation to Ore Deposits (Second Edition). John Wiley and Sons, New York, $444 \mathrm{p}$.

Smith, E.A. and Fyffe, L.R. 2006a. Bedrock geology of central New Brunswick (NTS 21 J). New Brunswick Department of Natural Resources; Minerals, Policy and Planning Division, Plate NR-4 (Second Edition), 1:50 000-scale.

Smith, E.A., and Fyffe, L.R. (compilers) 2006b. Bedrock geology of the Tuadook Lake area (NTS $21 \mathrm{~J} / 15$ ), Carleton, York, Northumberland and Victoria counties, New Brunswick. New Brunswick Department of Natural Resources; Minerals, Policy and Planning Division, Plate 2006-16, 1:50 000-scale.

St. Peter, C. 1981. Geology of North Branch Southwest Miramichi River (mapareas J14, J15, J16). New Brunswick Department of Natural Resources, Mineral Resources Branch, Map Report 801, 61 p.

St. Peter, C. 1982. Geology of Juniper-Knowlesville-Carlisle area, map areas I16, I17, I18 (Parts of $21 \mathrm{~J} / 11$ and 21 J/06). New Brunswick Department of Natural Resources, Geological Surveys Branch, Map Report 821, 82 p.

Streckeisen, A.L. and LeMaitre, R.W. 1979. Chemical approximation to the modal QAPF classification of the igneous rocks. Neues Jahrbuch für Mineralogie, 136, pp. 169-206.

Sun, S.-S. and McDonough, W.F. 1989. Chemical and isotopic systematics of oceanic basalts: Implications for mantle composition and processes. Geological Society of London, Special Publication 42, pp. 313-345. http:// dx.doi.org/10.1144/GSL.SP.1989.042.01.19

Tauson, L.V. and Kozlov, V.D. 1973. Distribution functions and ratios as estimators of ore-bearing potential of granites. In Geochemical Exploration 1972. Edited by M.J. Jones. Institute of Mining and Metallurgy, London, pp. 37-44.

Taylor, R.P., Lux, D.R., MacLellan, H.E., and Hubacher, F. 1987. Age and genesis of granite-related W-Sn-Mo mineral deposits, Burnthill, New Brunswick, Canada. Economic Geology, 82, pp. 2187-2198. http://dx.doi. org/10.2113/gsecongeo.82.8.2187

van Staal, C.R. and de Roo, J.A. 1995. Mid-Paleozoic 
tectonic evolution of the Appalachian Central Mobile Belt in northern New Brunswick, Canada: collision, extensional collapse and dextral transpression. In Current Perspectives in the Appalachian-Caledonian Orogen. Edited by J.P. Hibbard, C.R. van Staal, and P.A. Cawood. Geological Association of Canada, Special Paper 41, pp. 367-389.

van Staal, C.R., Wilson, R.A., Rogers, N., Fyffe, L.R., Langton, J.P., McCutcheon, S.R., McNicoll, V., and Ravenhurst, C.E. 2003. Geology and tectonic history of the Bathurst Supergroup, Bathurst Mining Camp, and its relationships to coeval rocks in southwestern New Brunswick and adjacent Maine-a synthesis. Economic Geology Monograph 11, pp. 37-60.

van Staal, C.R., Whalen, J.B., Valverde-Vaquero, P., Zagorevski, A., and Rogers, N. 2009. Pre-Carboniferous, episodic accretion-related, orogenesis along the Laurentian margin of the northern Appalachians. In Ancient Orogens and Modern Analogues. Edited by J.B. Murphy, J.D. Keppie, and A.J. Hynes. Geological Society of London, Special Publication 327, pp. 271-316. http:// dx.doi.org/10.1144/sp327.13

van Staal, C.R., Barr, S.M., and Murphy, J.B. 2012. Provenance and tectonic evolution of Ganderia: constraints on the evolution of the Iapetus and Rheic oceans. Geology, 40, pp. 987-990. http://dx.doi.org/10.1130/G33302.1

van Staal, C.R., Wilson, R.A., Kamo, S.L., McClelland, W.C., and McNicoll, V. 2016. Evolution of the Early to Middle Ordovician Popelogan arc in New Brunswick, Canada and adjacent Maine, USA: Record of arc-trench migration and multiple phases of rifting. Geological Society of America Bulletin, 127, pp. 122-146. http://dx.doi.org/10.1130/ b31253.1

Walker, J.A. and Clark, D. 2012. The Mount Costigan Zn$\mathrm{Pb}-\mathrm{Ag}$ deposit, west-central New Brunswick, Canada: Stratigraphic setting and evolution of felsic intrusionrelated mineralization. New Brunswick Department of Energy and Mines, Geological Surveys Branch, Mineral Resource Report 2012-2: Paper 2, 50 p.

Wedepohl,K.H.1995.Thecomposition ofthecontinentalcrust. Geochimica et Cosmochimica Acta, 59, pp. 1217-1232. http://dx.doi.org/10.1016/0016-7037(95)00038-2

Whalen, J.B. 1993. Geology, petrography, and geochemistry of Appalachian granites in New Brunswick and Gaspésie, Quebec. Geological Survey of Canada, Bulletin 436, 124 p. http://dx.doi.org/10.4095/183907

Whalen, J.B. and Frost, C.D. 2013. The Q-ANOR diagram: A tool for the petrogenetic and tectonomagmatic characterization of granitic suites. Geological Society of America, South-Central Section, Abstracts with Programs, 45, no. 3, p. 24.

Whalen, J.B. and Theriault, R. 1990. K-Ar and Rb-Sr geochronology of granites, Miramichi Terrane, New Brunswick. In Radiogenic Age and Isotopic Studies,
Report 3. Geological Survey of Canada, Paper 89-2, pp. 101-107.

Whalen, J.B., Jenner, G.A., Hegner, E., Gariégy, C., and Longstaffe, F.J. 1994. Geochemical and isotopic (Nd, O, and $\mathrm{Pb}$ ) constraints on granite sources in the Humber and Dunnage zones, Gaspésie, Quebec, and New Brunswick: implications for tectonics and crustal structure. Canadian Journal of Earth Sciences, 31, pp. 323-340. http://dx.doi. org/10.1139/e94-030

Whalen, J.B., Jenner, G.A., Longstaffe, F.J., and Hegner, E. 1996. Nature and evolution of the eastern margin of Iapetus: geochemical and isotopic constraints from Siluro-Devonian granitoid plutons in the New Brunswick Appalachians. Canadian Journal of Earth Sciences, 33, pp. 140-155. http://dx.doi.org/10.1139/e96-014

Whalen, J.B., Rogers, N., van Staal, C.R., Longstaffe, F.J., Jenner, G.A., and Winchester, J.A. 1998. Geochemical and isotopic $(\mathrm{Nd}, \mathrm{O})$ data from Ordovician felsic plutonic and volcanic rocks of the Miramichi Highlands: petrogenetic and metallogenic implications for the Bathurst Mining Camp. Canadian Journal of Earth Sciences, 35, pp. 237-252. http://dx.doi.org/10.1139/e97-102

Wilson, R.A. 2003. Geochemistry and petrogenesis of Ordovician arc-related mafic volcanic rocks in the Popelogan Inlier, northern New Brunswick. Canadian Journal of Earth Sciences, 40, pp. 1171-1189. http:// dx.doi.org/10.1139/e03-034

Wilson, R.A. and Kamo, S.L. 2008. New U-Pb ages from the Chaleurs and Dalhousie groups: Implications for regional correlations and tectonic evolution of northern New Brunswick. In Geological Investigations in New Brunswick for 2007. Edited by G.L. Martin. New Brunswick Department of Natural Resources; Minerals, Policy and Planning Division, Mineral Resource Report 2008-1, pp. 55-77.

Wilson, R.A. and Kamo, S.L. 2012. The Salinic Orogeny in northern New Brunswick: geochronological constraints and implications for Silurian stratigraphic nomenclature. Canadian Journal of Earth Sciences, 49, pp. 222-238.

Wilson, R.A., Kamo, S., and Burden, E.T. 2005. Geology of the Val d'Amour Formation: Revisiting the type area of the Dalhousie Group, northern New Brunswick. In Geological Investigations in New Brunswick for 2004. Edited by G.L. Martin. New Brunswick Department of Natural Resources; Minerals, Policy and Planning Division, Mineral Resources Report 2005-1, pp. 167-212.

Winchester, J.A., van Staal, C.R., and Fyffe, L.R. 1992. Ordovician volcanic and hypabyssal rocks in the central and southern Miramichi Highlands: their tectonic setting and relationship to contemporary volcanic rocks in northern New Brunswick. Atlantic Geology, 28, pp. 171-179. http://dx.doi.org/10.4138/1859

Zhang, W. 2015. Petrological and Metallogenic studies of the Nashwaak Granite and felsic dykes associated with 
the Sisson Book W-Mo-(Cu) deposit, west-central New Brunswick, Canada. Unpublished $\mathrm{PhD}$ thesis, University of New Brunswick, Fredericton, New Brunswick, 270 p.

Editorial responsibility: Sandra M. Barr

\section{APPENDIX A: ANALYTICAL METHODS}

\section{Geochronology}

$\mathrm{U}-\mathrm{Pb}$ analyses were performed at the Jack Satterly Geochronology Laboratory in the Department of Earth Sciences, University of Toronto, by isotope dilution thermal ionization mass spectrometry (ID-TIMS) methods. Rocks were crushed and pulverized using standard methods with a jaw crusher and disk mill. A Wilfley table was used to produce a concentrate of heavy minerals. Zircon was isolated using methylene iodide and a Frantz magnetic separator. Prior to dissolution, zircon grains were chemically abraded to penetratively remove alteration zones where $\mathrm{Pb}$ loss has occurred (Mattinson 2005). These zones correlate with areas of high $U$ that have suffered radiation damage prior to alteration. To thermally anneal damaged lattice sites, grains were placed in a muffle furnace at $\sim 1000^{\circ} \mathrm{C}$ for up to $60 \mathrm{~h}$. This was followed by partial dissolution in $50 \% \mathrm{HF}$ and $\sim 10 \mu \mathrm{l} 8 \mathrm{~N} \mathrm{HNO}_{3}$ in Teflon dissolution vessels at $195^{\circ} \mathrm{C}$

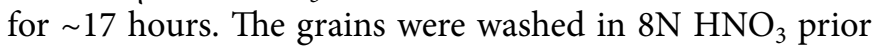
to dissolution. A mixed ${ }^{205} \mathrm{~Pb}^{233-235} \mathrm{U}$ spike (ET535 tracer from the EARTHTIME Project) was added to the Teflon dissolution capsules during sample loading. The zircon was dissolved using $\sim 0.10 \mathrm{~mL}$ of concentrated hydrofluoric acid (HF) and $\sim 0.02 \mathrm{~mL}$ of $8 \mathrm{~N}$ nitric acid $\left(\mathrm{HNO}_{3}\right)$ at $195^{\circ} \mathrm{C}$ (Krogh 1973) for $\sim 5$ days, then dried to a precipitate, and re-dissolved in $\sim 0.15 \mathrm{~mL}$ of $3 \mathrm{~N}$ hydrochloric acid $(\mathrm{HCl})$. $\mathrm{U}$ and $\mathrm{Pb}$ were isolated from the zircon solutions using anion exchange chromatography, then dried in dilute phosphoric acid $\left(\mathrm{H}_{3} \mathrm{PO}_{4}\right)$, and deposited onto outgassed rhenium filaments with silica gel (Gerstenberger and Haase 1997). Pb was analyzed with a VG354 mass spectrometer in dynamic mode with a Daly pulse-counting system. $U$ was measured using the Daly detector or in static mode using three Faraday collectors. Corrections for isobaric interferences from ${ }^{233} \mathrm{UO}_{16} \mathrm{O}_{18}$ on ${ }^{235} \mathrm{UO}_{2}$ at mass 267 have been made. The dead time of the Daly measuring system for $\mathrm{Pb}$ and $\mathrm{U}$ was 16.5 and $14.5 \mathrm{~ns}$, respectively. The mass discrimination correction for the Daly detector is constant at $0.05 \%$ /atomic mass unit. Daly characteristics were monitored using the SRM $982 \mathrm{~Pb}$ standard. Thermal mass fractionation for $\mathrm{Pb}$ was $0.1 \%$ per atomic mass unit, and that for $\mathrm{U}$ was measured and corrected within each cycle. The total common $\mathrm{Pb}$ in each zircon analysis was attributed to laboratory $\mathrm{Pb}$ (corrected using an isotopic composition of ${ }^{206} \mathrm{~Pb} /{ }^{204} \mathrm{~Pb}$ of $18.49 \pm 0.4 \%,{ }^{207} \mathrm{~Pb} /{ }^{204} \mathrm{~Pb}$ of $15.59 \pm 0.4 \%,{ }^{208} \mathrm{~Pb} /{ }^{204} \mathrm{~Pb}$ of 39.36 $\pm 0.4 \%$; $2 \sigma$ uncertainties), thus no correction for initial common $\mathrm{Pb}$ from geological sources was made. Routine testing indicates that laboratory blanks for $\mathrm{Pb}$ and $\mathrm{U}$ are usually contain less than $0.5 \mathrm{pg}$ and $0.01 \mathrm{pg}$, respectively. Corrections to the ${ }^{206} \mathrm{~Pb} /{ }^{238} \mathrm{U}$ and ${ }^{207} \mathrm{~Pb} /{ }^{206} \mathrm{~Pb}$ ages for initial ${ }^{230} \mathrm{Th}$ disequilibrium were made assuming a $\mathrm{Th} / \mathrm{U}$ ratio in the magma of 4.2. Decay constants are those of Jaffey et al. (1971). All age errors quoted in the text and tables, and error ellipses in the concordia diagrams are given at $2 \sigma$. Plotting and age calculations are from Isoplot/Ex 3.00 (Ludwig 2003).

\section{Lithogeochemistry}

Sixty-eight samples of fresh, unaltered granite and granodiorite from ten plutons were submitted for lithogeochemical analysis at Activation Laboratories Ltd. in Ancaster, ON. Samples were subjected to lithium metaborate/tetraborate fusion and the resulting molten bead digested in a weak nitric acid solution. Analyses were carried out by inductively-coupled plasma optical emission spectrometry (major oxides, $\mathrm{Ba}, \mathrm{Be}, \mathrm{Sc}, \mathrm{Sr}$, and $\mathrm{V})$, and inductively-coupled plasma mass spectrometry (Bi, Co, Cs, Ga, Ge, Hf, In, Mo, Nb, Rb, Sn, Ta, Tl, U, W, Y, $\mathrm{Zr}$, and rare-earth elements). Silver, $\mathrm{Cd}, \mathrm{Cu}, \mathrm{Ni}, \mathrm{Pb}, \mathrm{S}$, and $\mathrm{Zn}$ were analyzed by multi-acid digestion and inductivelycoupled plasma mass spectrometry, and $\mathrm{As}, \mathrm{Au}, \mathrm{Cr}, \mathrm{Sb}$, and Th by instrumental neutron activation analysis.

Twelve repeat analyses of an internal granite standard yielded excellent to very good repeatability for major oxides (average $<2 \%$ variation, except $5.8 \%$ for $\mathrm{P}_{2} \mathrm{O}_{5}$ ) and most reported trace elements $(0-10 \%)$, except for $\mathrm{Cu}, \mathrm{Ge}, \mathrm{Nb}$, $\mathrm{Pb}(10-20 \%$ variation) and $\mathrm{Ag}, \mathrm{As}, \mathrm{Bi} \mathrm{Sb}$, and $\mathrm{W}(>20 \%$ variation). Analytical methods, precision and accuracy for data incorporated from the other sources cited in this paper are given by Whalen (1993) and MacLellan and Taylor (1989). Although the analytical methods used to acquire the older data (mainly X-Ray Fluorescence Spectroscopy and Instrumental Neutron Activation Analysis) differ from those used in this study, the high quality of the older data (based on the labs used, the precision and accuracy figures reported by Whalen (1993) and MacLellan and Taylor (1989), and the congruity of old and newly acquired data when plotted on variation/discrimination diagrams) supports the use of a combined dataset. 
APPENDIX B. Lithogeochemical analyses of granitoid rocks from the Central plutonic belt. See text for description of analytical methods.

\begin{tabular}{|c|c|c|c|c|c|c|c|c|c|c|c|c|}
\hline $\begin{array}{c}\text { Sample \# } \\
\text { Pluton } \\
\text { Age }\end{array}$ & & $\begin{array}{c}\text { 12-SHM-44 } \\
\text { Burnthill } \\
\text { Late } \\
\text { Devonian }\end{array}$ & $\begin{array}{c}\text { 12-SHM-45 } \\
\text { Burnthill } \\
\text { Late } \\
\text { Devonian }\end{array}$ & $\begin{array}{c}\text { 12-SHM-47 } \\
\text { Burnthill } \\
\text { Late } \\
\text { Devonian }\end{array}$ & $\begin{array}{c}\text { 12-SHM-50 } \\
\text { Burnthill } \\
\text { Late } \\
\text { Devonian }\end{array}$ & $\begin{array}{c}\text { 12-SHM-53 } \\
\text { Burnthill } \\
\text { Late } \\
\text { Devonian }\end{array}$ & $\begin{array}{c}\text { 12-SHM-54 } \\
\text { Burnthill } \\
\text { Late } \\
\text { Devonian }\end{array}$ & $\begin{array}{c}\text { 12-SHM-55 } \\
\text { Burnthill } \\
\text { Late } \\
\text { Devonian }\end{array}$ & $\begin{array}{c}\text { 12-SHM-28 } \\
\text { Burnthill } \\
\text { Late } \\
\text { Devonian }\end{array}$ & $\begin{array}{c}\text { 12-SHM-29 } \\
\text { Burnthill } \\
\text { Late } \\
\text { Devonian }\end{array}$ & $\begin{array}{c}\text { 12-SHM-40 } \\
\text { Burnthill } \\
\text { Late } \\
\text { Devonian }\end{array}$ & $\begin{array}{c}\text { 12-SHM-51 } \\
\text { Burnthill } \\
\text { Late } \\
\text { Devonian }\end{array}$ \\
\hline $\mathrm{SiO}_{2}$ & $\%$ & 78.44 & 76.27 & 77.45 & 71.60 & 76.82 & 72.41 & 75.66 & 75.97 & 77.20 & 74.36 & 73.41 \\
\hline $\mathrm{TiO}_{2}$ & $\%$ & 0.09 & 0.05 & 0.16 & 0.38 & 0.11 & 0.31 & 0.09 & 0.17 & 0.13 & 0.20 & 0.23 \\
\hline $\mathrm{Al}_{2} \mathrm{O}_{3}$ & $\%$ & 12.09 & 12.39 & 12.55 & 14.92 & 12.54 & 13.80 & 12.32 & 12.79 & 12.52 & 12.59 & 12.90 \\
\hline $\mathrm{Fe}_{2} \mathrm{O}_{3}$ & $\%$ & 1.20 & 0.79 & 1.58 & 2.83 & 1.39 & 2.38 & 1.09 & 1.64 & 1.47 & 1.72 & 1.78 \\
\hline $\mathrm{MnO}$ & $\%$ & 0.04 & 0.02 & 0.05 & 0.08 & 0.03 & 0.07 & 0.03 & 0.05 & 0.06 & 0.06 & 0.05 \\
\hline $\mathrm{MgO}$ & $\%$ & 0.08 & 0.04 & 0.23 & 0.79 & 0.11 & 0.60 & 0.10 & 0.22 & 0.14 & 0.26 & 0.30 \\
\hline $\mathrm{CaO}$ & $\%$ & 0.36 & 0.27 & 0.52 & 2.30 & 0.72 & 1.74 & 0.49 & 0.62 & 0.53 & 0.63 & 0.89 \\
\hline $\mathrm{Na}_{2} \mathrm{O}$ & $\%$ & 3.34 & 3.63 & 3.19 & 3.90 & 3.29 & 3.70 & 3.28 & 3.09 & 3.31 & 3.10 & 3.20 \\
\hline $\mathrm{K}_{2} \mathrm{O}$ & $\%$ & 4.51 & 4.59 & 4.58 & 3.09 & 4.58 & 3.81 & 4.86 & 4.91 & 4.39 & 4.64 & 4.69 \\
\hline $\mathrm{P}_{2} \mathrm{O}_{5}$ & $\%$ & 0.03 & 0.02 & 0.04 & 0.10 & 0.02 & 0.08 & 0.02 & 0.05 & 0.03 & 0.05 & 0.08 \\
\hline LOI & $\%$ & 0.48 & 0.51 & 0.62 & 0.99 & 0.39 & 0.72 & 0.50 & 0.69 & 0.69 & 0.68 & 0.71 \\
\hline TOTAL & $\%$ & 100.70 & 98.59 & 101.00 & 101.00 & 100.00 & 99.62 & 98.44 & 100.20 & 100.50 & 98.29 & 98.23 \\
\hline $\mathrm{Ag}$ & ppm & $<0.3$ & $<0.3$ & 0.4 & 0.4 & $<0.3$ & 0.4 & 0.3 & 0.3 & $<0.3$ & $<0.3$ & 0.4 \\
\hline As & ppm & $<0.5$ & $<0.5$ & $<0.5$ & $<0.5$ & $<0.5$ & $<0.5$ & $<0.5$ & $<0.5$ & $<0.5$ & $<0.5$ & $<0.5$ \\
\hline $\mathrm{Au}$ & ppb & $<2$ & $<2$ & $<2$ & $<2$ & $<2$ & $<2$ & $<2$ & $<2$ & $<2$ & $<2$ & $<2$ \\
\hline $\mathrm{Ba}$ & ppm & 37 & 23 & 68 & 434 & 52 & 320 & 76 & 126 & 90 & 126 & 216 \\
\hline $\mathrm{Be}$ & $\mathrm{ppm}$ & 7 & 6 & 7 & 6 & 7 & 7 & 7 & 8 & 12 & 7 & 7 \\
\hline $\mathrm{Bi}$ & ppm & 0.1 & 10.4 & 2.4 & 5.2 & $<0.1$ & 0.4 & 0.1 & 0.3 & 0.6 & 0.1 & 0.2 \\
\hline $\mathrm{Cd}$ & ppm & $<0.5$ & $<0.5$ & $<0.5$ & $<0.5$ & $<0.5$ & $<0.5$ & $<0.5$ & $<0.5$ & $<0.5$ & 0.9 & $<0.5$ \\
\hline Co & ppm & 1.0 & $<1$ & 1.0 & 5.0 & 1.0 & 3.0 & $<1$ & 2.0 & 1.0 & 2.0 & 2.0 \\
\hline $\mathrm{Cr}$ & $\mathrm{ppm}$ & 33 & 40 & 28 & 15 & 21 & 26 & 22 & 34 & 23 & 22 & 15 \\
\hline Cs & ppm & 6.5 & 4.8 & 4.7 & 12.4 & 8.6 & 9.1 & 5.2 & 9.3 & 9.5 & 5.9 & 5.3 \\
\hline $\mathrm{Cu}$ & ppm & 6 & 9 & 3 & 54 & 4 & $<1$ & 2 & 10 & 6 & 24 & 2 \\
\hline $\mathrm{Ga}$ & ppm & 21 & 21 & 20 & 21 & 21 & 20 & 18 & 21 & 22 & 19 & 19 \\
\hline $\mathrm{Ge}$ & ppm & 3.8 & 2.9 & 3.0 & 2.4 & 2.8 & 1.8 & 2.3 & 2.7 & 2.9 & 2.1 & 2.0 \\
\hline $\mathrm{Hf}$ & ppm & 4.1 & 3.8 & 4.5 & 4.2 & 3.9 & 4.1 & 2.3 & 3.5 & 3.4 & 3.4 & 3.4 \\
\hline In & ppm & $<0.1$ & $<0.1$ & $<0.1$ & $<0.1$ & $<0.1$ & $<0.1$ & $<0.1$ & $<0.1$ & $<0.1$ & $<0.1$ & $<0.1$ \\
\hline Mo & ppm & $<2.0$ & 4.0 & $<2.0$ & 2.0 & $<2.0$ & $<2.0$ & $<2.0$ & $<2.0$ & $<2.0$ & $<2.0$ & $<2.0$ \\
\hline $\mathrm{Nb}$ & $\mathrm{ppm}$ & 41.8 & 40.6 & 26.9 & 13.3 & 24.2 & 12.9 & 19.5 & 20.0 & 26.2 & 16.1 & 16.0 \\
\hline $\mathrm{Ni}$ & $\mathrm{ppm}$ & 2 & 2 & 2 & 6 & 1 & 5 & 1 & 3 & 3 & 1 & 3 \\
\hline $\mathrm{Pb}$ & ppm & 32 & 35 & 32 & 14 & 33 & 19 & 36 & 32 & 35 & 31 & 30 \\
\hline $\mathrm{Rb}$ & ppm & 466 & 443 & 355 & 240 & 331 & 251 & 353 & 424 & 452 & 326 & 310 \\
\hline $\mathrm{S}$ & $\%$ & 0.008 & 0.004 & 0.005 & 0.068 & 0.004 & 0.020 & 0.004 & 0.004 & 0.004 & 0.005 & 0.005 \\
\hline $\mathrm{Sb}$ & $\mathrm{ppm}$ & 0.4 & $<0.2$ & 0.5 & $<0.2$ & $<0.2$ & $<0.2$ & $<0.2$ & $<0.2$ & $<0.2$ & $<0.2$ & $<0.2$ \\
\hline $\mathrm{Sc}$ & $\mathrm{ppm}$ & 6.0 & 5.0 & 5.0 & 6.0 & 4.0 & 5.0 & 3.0 & 5.0 & 5.0 & 5.0 & 4.0 \\
\hline Sn & ppm & 8.0 & 11.0 & 7.0 & 26.0 & 8.0 & 10.0 & 6.0 & 9.0 & 13.0 & 8.0 & 7.0 \\
\hline $\mathrm{Sr}$ & ppm & 23 & 14 & 42 & 334 & 39 & 220 & 39 & 55 & 49 & 60 & 97 \\
\hline $\mathrm{Ta}$ & $\mathrm{ppm}$ & 8.53 & 11.70 & 4.19 & 1.65 & 4.67 & 3.25 & 4.16 & 5.77 & 6.08 & 3.81 & 3.44 \\
\hline Th & $\mathrm{ppm}$ & 42.80 & 29.50 & 43.80 & 19.50 & 36.10 & 23.00 & 29.20 & 36.70 & 38.60 & 43.70 & 32.70 \\
\hline $\mathrm{Tl}$ & $\mathrm{ppm}$ & 2.70 & 2.76 & 1.83 & 1.72 & 1.71 & 1.38 & 1.67 & 1.94 & 2.10 & 1.60 & 1.68 \\
\hline $\mathrm{U}$ & ppm & 30.30 & 33.60 & 15.20 & 7.52 & 15.60 & 6.91 & 13.50 & 14.00 & 15.90 & 11.60 & 5.95 \\
\hline $\mathrm{V}$ & $\mathrm{ppm}$ & 6 & $<5$ & 11 & 35 & 7 & 29 & 8 & 12 & 8 & 14 & 19 \\
\hline $\mathrm{W}$ & $\mathrm{ppm}$ & 1.5 & 6.6 & 13.3 & 145.0 & 5.3 & 1.0 & 1.1 & 5.0 & 1.9 & $<0.5$ & 1.7 \\
\hline $\mathrm{Y}$ & $\mathrm{ppm}$ & 97.9 & 127.0 & 51.0 & 23.8 & 49.0 & 36.2 & 45.2 & 48.2 & 66.0 & 45.3 & 34.8 \\
\hline $\mathrm{Zn}$ & ppm & 18 & 17 & 47 & 65 & 23 & 75 & 21 & 31 & 36 & 106 & 27 \\
\hline $\mathrm{Zr}$ & $\mathrm{ppm}$ & 103 & 72 & 136 & 172 & 98 & 157 & 60 & 113 & 94 & 117 & 122 \\
\hline $\mathrm{La}$ & $\mathrm{ppm}$ & 22.80 & 16.30 & 24.30 & 41.50 & 11.90 & 29.50 & 16.90 & 24.80 & 27.20 & 29.30 & 26.00 \\
\hline $\mathrm{Ce}$ & ppm & 57.50 & 44.20 & 58.20 & 80.60 & 30.40 & 59.70 & 37.90 & 55.90 & 61.20 & 65.40 & 58.20 \\
\hline $\operatorname{Pr}$ & $\mathrm{ppm}$ & 7.26 & 6.26 & 7.34 & 8.92 & 4.09 & 7.08 & 4.99 & 6.88 & 7.65 & 7.99 & 6.95 \\
\hline $\mathrm{Nd}$ & $\mathrm{ppm}$ & 27.10 & 25.60 & 27.30 & 31.80 & 16.40 & 25.50 & 20.30 & 25.50 & 28.20 & 29.40 & 25.60 \\
\hline Sm & $\mathrm{ppm}$ & 8.45 & 9.27 & 6.94 & 6.17 & 4.92 & 5.50 & 5.50 & 5.89 & 7.45 & 7.08 & 5.52 \\
\hline $\mathrm{Eu}$ & $\mathrm{ppm}$ & 0.18 & 0.10 & 0.30 & 0.87 & 0.28 & 0.62 & 0.30 & 0.35 & 0.26 & 0.41 & 0.52 \\
\hline $\mathrm{Gd}$ & ppm & 8.91 & 10.90 & 6.27 & 4.98 & 5.09 & 4.83 & 5.53 & 5.56 & 7.12 & 6.03 & 4.95 \\
\hline $\mathrm{Tb}$ & ppm & 1.88 & 2.49 & 1.16 & 0.73 & 1.03 & 0.88 & 1.12 & 1.07 & 1.44 & 1.13 & 0.85 \\
\hline Dy & ppm & 13.20 & 17.40 & 7.43 & 4.22 & 6.46 & 5.21 & 7.03 & 6.88 & 9.63 & 7.26 & 5.53 \\
\hline Ho & ppm & 2.76 & 3.62 & 1.51 & 0.79 & 1.29 & 1.03 & 1.41 & 1.38 & 1.97 & 1.36 & 1.09 \\
\hline $\mathrm{Er}$ & $\mathrm{ppm}$ & 8.59 & 11.60 & 4.58 & 2.29 & 4.24 & 3.30 & 4.48 & 4.50 & 6.28 & 4.28 & 3.25 \\
\hline $\mathrm{Tm}$ & $\mathrm{ppm}$ & 1.56 & 2.08 & 0.81 & 0.36 & 0.80 & 0.57 & 0.78 & 0.76 & 1.10 & 0.72 & 0.54 \\
\hline $\mathrm{Yb}$ & ppm & 10.50 & 14.60 & 5.70 & 2.40 & 5.46 & 3.90 & 5.30 & 5.15 & 7.56 & 4.75 & 3.78 \\
\hline $\mathrm{Lu}$ & $\mathrm{ppm}$ & 1.50 & 2.10 & 0.92 & 0.38 & 0.86 & 0.54 & 0.72 & 0.75 & 1.10 & 0.68 & 0.55 \\
\hline
\end{tabular}


APPENDIX B. Continued.

\begin{tabular}{|c|c|c|c|c|c|c|c|c|c|c|c|}
\hline $\begin{array}{c}\text { Sample \# } \\
\text { Pluton } \\
\text { Age }\end{array}$ & $\begin{array}{c}\text { 12-SHM-52 } \\
\text { Burnthill } \\
\text { Late } \\
\text { Devonian }\end{array}$ & $\begin{array}{l}\text { 12-SHM-56 } \\
\text { Burnthill } \\
\text { Late } \\
\text { Devonian }\end{array}$ & $\begin{array}{l}\text { 12-SHM-65 } \\
\text { Burnthill } \\
\text { Late } \\
\text { Devonian }\end{array}$ & $\begin{array}{l}\text { 12-SHM-15 } \\
\text { Lost Lake } \\
\text { Early } \\
\text { Devonian }\end{array}$ & $\begin{array}{l}\text { 11-SHM-31 } \\
\text { Lost Lake } \\
\text { Early } \\
\text { Devonian }\end{array}$ & $\begin{array}{l}\text { 11-SHM-32 } \\
\text { Lost Lake } \\
\text { Early } \\
\text { Devonian }\end{array}$ & $\begin{array}{l}\text { 11-SHM-1 } \\
\text { Lost Lake } \\
\text { Early } \\
\text { Devonian }\end{array}$ & $\begin{array}{c}\text { 11-SHM-4 } \\
\text { Lost Lake } \\
\text { Early } \\
\text { Devonian }\end{array}$ & $\begin{array}{l}\text { 12-SHM-16 } \\
\text { Lost Lake } \\
\text { Early } \\
\text { Devonian }\end{array}$ & $\begin{array}{c}\text { 12-SHM-2 } \\
\text { Beadle Mtn. } \\
\text { Early } \\
\text { Devonian }\end{array}$ & $\begin{array}{c}\text { 12-SHM-5 } \\
\text { Beadle Mtn. } \\
\text { Early } \\
\text { Devonian }\end{array}$ \\
\hline $\mathrm{SiO}_{2}$ & 76.54 & 74.85 & 76.94 & 73.94 & 75.86 & 74.26 & 73.06 & 69.06 & 68.86 & 77.25 & 67.92 \\
\hline $\mathrm{TiO}_{2}$ & 0.13 & 0.20 & 0.21 & 0.16 & 0.06 & 0.06 & 0.40 & 0.67 & 0.45 & 0.21 & 0.70 \\
\hline $\mathrm{Al}_{2} \mathrm{O}_{3}$ & 12.55 & 12.32 & 12.05 & 14.65 & 14.45 & 14.03 & 14.09 & 14.07 & 15.73 & 11.82 & 14.15 \\
\hline $\mathrm{Fe}_{2} \mathrm{O}_{3}$ & 1.38 & 1.68 & 2.16 & 1.47 & 0.84 & 0.76 & 2.75 & 4.02 & 3.24 & 1.90 & 3.98 \\
\hline $\mathrm{MnO}$ & 0.06 & 0.06 & 0.05 & 0.04 & 0.01 & 0.02 & 0.06 & 0.07 & 0.07 & 0.04 & 0.07 \\
\hline $\mathrm{MgO}$ & 0.14 & 0.24 & 0.12 & 0.21 & 0.08 & 0.05 & 0.79 & 1.13 & 0.95 & 0.27 & 1.07 \\
\hline $\mathrm{CaO}$ & 0.49 & 0.70 & 0.52 & 0.62 & 0.36 & 0.40 & 1.27 & 2.19 & 3.04 & 0.89 & 1.21 \\
\hline $\mathrm{Na}_{2} \mathrm{O}$ & 3.36 & 3.15 & 3.10 & 3.09 & 3.48 & 3.53 & 2.96 & 3.13 & 3.74 & 2.82 & 3.38 \\
\hline $\mathrm{K}_{2} \mathrm{O}$ & 4.78 & 4.64 & 4.99 & 5.16 & 4.42 & 4.22 & 3.89 & 4.06 & 2.81 & 3.86 & 4.33 \\
\hline $\mathrm{P}_{2} \mathrm{O}_{5}$ & 0.03 & 0.06 & 0.03 & 0.23 & 0.19 & 0.24 & 0.18 & 0.17 & 0.18 & 0.07 & 0.18 \\
\hline LOI & 0.49 & 0.56 & 0.62 & 1.03 & 0.90 & 0.84 & 1.26 & 0.79 & 1.24 & 0.70 & 1.36 \\
\hline TOTAL & 99.96 & 98.45 & 100.80 & 100.60 & 100.60 & 98.41 & 100.70 & 99.36 & 100.30 & 99.83 & 98.36 \\
\hline $\mathrm{Ag}$ & $<0.3$ & $<0.3$ & $<0.3$ & $<0.3$ & $<0.3$ & $<0.3$ & $<0.3$ & $<0.3$ & $<0.3$ & 0.3 & $<0.3$ \\
\hline As & $<0.5$ & $<0.5$ & 7.4 & $<0.5$ & $<0.5$ & $<0.5$ & $<0.5$ & $<0.5$ & $<0.5$ & $<0.5$ & $<0.5$ \\
\hline $\mathrm{Au}$ & $<2$ & $<2$ & $<2$ & $<2$ & $<2$ & $<2$ & $<2$ & $<2$ & $<2$ & $<2$ & $<2$ \\
\hline $\mathrm{Ba}$ & 77 & 109 & 33 & 261 & 11 & 9 & 364 & 454 & 441 & 204 & 454 \\
\hline $\mathrm{Be}$ & 7 & 9 & 7 & 5 & 2 & 2 & 5 & 3 & 4 & 3 & 3 \\
\hline $\mathrm{Bi}$ & 0.1 & 1.2 & 60.0 & 0.7 & 0.4 & 7.3 & 1.4 & 1.4 & 0.1 & 10.3 & 0.5 \\
\hline $\mathrm{Cd}$ & $<0.5$ & $<0.5$ & $<0.5$ & $<0.5$ & $<0.5$ & $<0.5$ & $<0.5$ & $<0.5$ & $<0.5$ & $<0.5$ & $<0.5$ \\
\hline Co & $<1$ & 2.0 & 1.0 & 1.0 & $<1$ & $<1$ & 4.0 & 8.0 & 6.0 & 3.0 & 8.0 \\
\hline $\mathrm{Cr}$ & 25 & 22 & 26 & 23 & 12 & 6 & 26 & 35 & 18 & 17 & 26 \\
\hline Cs & 10.5 & 6.9 & 3.6 & 6.1 & 7.8 & 10.0 & 4.2 & 7.5 & 3.2 & 9.2 & 3.6 \\
\hline $\mathrm{Cu}$ & 3 & 11 & 3 & $<1$ & 11 & 2 & 12 & 11 & 7 & 23 & 14 \\
\hline $\mathrm{Ga}$ & 20 & 18 & 19 & 21 & 25 & 24 & 20 & 19 & 21 & 16 & 20 \\
\hline $\mathrm{Ge}$ & 2.6 & 2.1 & 2.3 & 1.9 & 2.3 & 2.3 & 1.6 & 2.0 & 1.9 & 2.3 & 2.2 \\
\hline $\mathrm{Hf}$ & 3.1 & 5.0 & 2.3 & 2.2 & 1.1 & 0.6 & 3.9 & 5.3 & 4.8 & 4.5 & 6.6 \\
\hline In & $<0.1$ & $<0.1$ & $<0.1$ & $<0.1$ & $<0.1$ & $<0.1$ & $<0.1$ & $<0.1$ & $<0.1$ & $<0.1$ & $<0.1$ \\
\hline Mo & $<2.0$ & $<2.0$ & 3.0 & $<2.0$ & $<2.0$ & $<2.0$ & $<2.0$ & $<2.0$ & $<2.0$ & 4.0 & $<2.0$ \\
\hline $\mathrm{Nb}$ & 21.2 & 17.8 & 10.3 & 13.4 & 17.5 & 11.7 & 15.0 & 15.3 & 11.7 & 12.4 & 10.9 \\
\hline $\mathrm{Ni}$ & 1 & 3 & 2 & 3 & 1 & 2 & 7 & 9 & 5 & 6 & 8 \\
\hline $\mathrm{Pb}$ & 33 & 32 & 34 & 36 & 15 & 16 & 28 & 17 & 14 & 21 & 17 \\
\hline $\mathrm{Rb}$ & 398 & 319 & 275 & 254 & 356 & 334 & 157 & 194 & 117 & 215 & 209 \\
\hline $\mathrm{s}$ & 0.003 & 0.009 & 0.006 & 0.004 & 0.003 & 0.002 & 0.006 & 0.011 & 0.012 & 0.007 & 0.007 \\
\hline $\mathrm{Sb}$ & $<0.2$ & 0.4 & $<0.2$ & $<0.2$ & $<0.2$ & $<0.2$ & $<0.2$ & $<0.2$ & $<0.2$ & $<0.2$ & $<0.2$ \\
\hline $\mathrm{Sc}$ & 5.0 & 5.0 & 5.0 & 3.0 & 4.0 & 3.0 & 5.0 & 10.0 & 6.0 & 5.0 & 9.0 \\
\hline Sn & 13.0 & 7.0 & 6.0 & 11.0 & 15.0 & 13.0 & 7.0 & 6.0 & 4.0 & 5.0 & 6.0 \\
\hline $\mathrm{Sr}$ & 30 & 54 & 37 & 51 & 8 & 9 & 140 & 147 & 272 & 46 & 106 \\
\hline $\mathrm{Ta}$ & 5.33 & 4.97 & 2.13 & 1.86 & 5.01 & 2.89 & 2.07 & 1.47 & 1.29 & 1.76 & 1.66 \\
\hline Th & 37.50 & 37.40 & 157.00 & 10.40 & 2.00 & 2.20 & 18.10 & 16.00 & 16.40 & 21.70 & 17.80 \\
\hline $\mathrm{Tl}$ & 1.97 & 1.59 & 1.32 & 1.14 & 1.74 & 1.77 & 0.89 & 0.96 & 0.70 & 1.13 & 0.91 \\
\hline $\mathrm{U}$ & 13.70 & 19.60 & 15.50 & 4.30 & 2.10 & 10.70 & 4.45 & 3.19 & 2.30 & 6.44 & 3.54 \\
\hline $\mathrm{V}$ & 9 & 13 & 9 & 8 & $<5$ & $<5$ & 33 & 66 & 39 & 19 & 65 \\
\hline $\mathrm{W}$ & 0.5 & 0.9 & 110.0 & 1.1 & 2.1 & 2.3 & 1.1 & 24.7 & $<0.5$ & 3.7 & 3.1 \\
\hline $\mathrm{Y}$ & 52.8 & 41.0 & 30.0 & 14.6 & 7.5 & 6.6 & 20.2 & 35.5 & 17.4 & 41.0 & 41.2 \\
\hline $\mathrm{Zn}$ & 28 & 33 & 31 & 50 & 34 & 33 & 66 & 61 & 62 & 27 & 58 \\
\hline $\mathrm{Zr}$ & 84 & 187 & 85 & 79 & 22 & 14 & 155 & 202 & 215 & 147 & 292 \\
\hline $\mathrm{La}$ & 23.60 & 25.00 & 82.00 & 14.00 & 1.73 & 1.56 & 32.90 & 32.10 & 35.20 & 24.90 & 39.50 \\
\hline $\mathrm{Ce}$ & 54.90 & 56.90 & 370.00 & 32.70 & 4.04 & 3.15 & 69.30 & 64.60 & 70.10 & 58.80 & 74.10 \\
\hline $\operatorname{Pr}$ & 6.92 & 7.05 & 24.70 & 3.79 & 0.45 & 0.37 & 7.81 & 7.70 & 8.05 & 6.47 & 9.35 \\
\hline $\mathrm{Nd}$ & 26.50 & 26.10 & 84.90 & 13.90 & 1.76 & 1.57 & 29.80 & 30.70 & 30.40 & 24.00 & 35.90 \\
\hline $\mathrm{Sm}$ & 6.72 & 6.10 & 14.70 & 3.63 & 0.76 & 0.66 & 6.32 & 6.67 & 5.17 & 5.16 & 7.21 \\
\hline $\mathrm{Eu}$ & 0.24 & 0.33 & 0.34 & 0.51 & 0.01 & 0.01 & 0.77 & 1.16 & 1.02 & 0.50 & 1.21 \\
\hline $\mathrm{Gd}$ & 6.22 & 5.15 & 9.01 & 3.58 & 0.99 & 0.92 & 5.37 & 6.57 & 4.23 & 5.02 & 6.99 \\
\hline $\mathrm{Tb}$ & 1.25 & 0.98 & 1.17 & 0.57 & 0.22 & 0.19 & 0.71 & 1.02 & 0.57 & 0.96 & 1.06 \\
\hline Dy & 7.67 & 6.30 & 6.00 & 2.84 & 1.22 & 1.05 & 3.77 & 5.80 & 2.87 & 6.25 & 6.56 \\
\hline Но & 1.53 & 1.21 & 1.01 & 0.43 & 0.20 & 0.17 & 0.61 & 1.13 & 0.50 & 1.31 & 1.25 \\
\hline Er & 4.89 & 3.79 & 2.99 & 1.07 & 0.56 & 0.50 & 1.70 & 3.42 & 1.42 & 4.30 & 3.72 \\
\hline $\mathrm{Tm}$ & 0.87 & 0.66 & 0.45 & 0.14 & 0.09 & 0.08 & 0.26 & 0.51 & 0.21 & 0.77 & 0.56 \\
\hline $\mathrm{Yb}$ & 5.78 & 4.37 & 2.79 & 0.90 & 0.61 & 0.57 & 1.66 & 3.19 & 1.30 & 5.60 & 3.71 \\
\hline $\mathrm{Lu}$ & 0.81 & 0.62 & 0.39 & 0.14 & 0.08 & 0.08 & 0.24 & 0.44 & 0.21 & 0.81 & 0.53 \\
\hline
\end{tabular}


APPENDIX B. Continued.

\begin{tabular}{|c|c|c|c|c|c|c|c|c|c|}
\hline $\begin{array}{c}\text { Sample \# } \\
\text { Pluton } \\
\text { Age }\end{array}$ & $\begin{array}{c}\text { 11-SHM-2 } \\
\text { Beadle Mtn. } \\
\text { Early } \\
\text { Devonian }\end{array}$ & $\begin{array}{l}\text { 11-SHM-30 } \\
\text { Beadle Mtn. } \\
\text { Early } \\
\text { Devonian }\end{array}$ & $\begin{array}{l}\text { 12-SHM-18 } \\
\text { Beadle Mtn. } \\
\text { Early } \\
\text { Devonian }\end{array}$ & $\begin{array}{l}\text { 11-SHM-11 } \\
\text { Beadle Mtn. } \\
\text { Early } \\
\text { Devonian }\end{array}$ & $\begin{array}{c}\text { 11-SHM-12 } \\
\text { Juniper Barren } \\
\text { Early Devonian }\end{array}$ & $\begin{array}{c}\text { 12-SHM-69 } \\
\text { Juniper Barren } \\
\text { Early Devonian }\end{array}$ & $\begin{array}{c}\text { 11-SHM-38 } \\
\text { Juniper Barren } \\
\text { Early Devonian }\end{array}$ & $\begin{array}{c}\text { 12-SHM-6 } \\
\text { Juniper Barren } \\
\text { Early Devonian }\end{array}$ & $\begin{array}{c}\text { 12-SHM-7 } \\
\text { Juniper Barren } \\
\text { Early Devonian }\end{array}$ \\
\hline $\mathrm{SiO}_{2}$ & 76.08 & 74.85 & 74.91 & 75.84 & 72.33 & 70.08 & 71.83 & 65.79 & 69.02 \\
\hline $\mathrm{TiO}_{2}$ & 0.12 & 0.16 & 0.13 & 0.11 & 0.21 & 0.66 & 0.51 & 0.95 & 0.62 \\
\hline $\mathrm{Al}_{2} \mathrm{O}_{3}$ & 13.40 & 14.09 & 13.89 & 13.93 & 15.77 & 14.32 & 14.24 & 15.11 & 13.88 \\
\hline $\mathrm{Fe}_{2} \mathrm{O}_{3}$ & 1.35 & 1.50 & 1.49 & 1.28 & 1.68 & 4.08 & 3.21 & 5.61 & 3.61 \\
\hline $\mathrm{MnO}$ & 0.04 & 0.03 & 0.05 & 0.04 & 0.04 & 0.08 & 0.06 & 0.10 & 0.07 \\
\hline $\mathrm{MgO}$ & 0.13 & 0.26 & 0.21 & 0.14 & 0.41 & 1.16 & 0.82 & 1.44 & 0.96 \\
\hline $\mathrm{CaO}$ & 0.43 & 0.66 & 0.53 & 0.39 & 0.71 & 2.12 & 1.66 & 2.76 & 2.17 \\
\hline $\mathrm{Na}_{2} \mathrm{O}$ & 3.24 & 2.84 & 3.14 & 3.09 & 2.98 & 3.19 & 3.18 & 3.19 & 3.03 \\
\hline $\mathrm{K}_{2} \mathrm{O}$ & 4.86 & 5.49 & 4.95 & 4.98 & 5.47 & 4.02 & 4.23 & 3.46 & 4.01 \\
\hline $\mathrm{P}_{2} \mathrm{O}_{5}$ & 0.10 & 0.18 & 0.20 & 0.21 & 0.20 & 0.17 & 0.14 & 0.24 & 0.17 \\
\hline LOI & 0.83 & 0.80 & 0.85 & 0.99 & 1.04 & 0.80 & 0.98 & 1.33 & 0.93 \\
\hline TOTAL & 100.60 & 100.80 & 100.30 & 101.00 & 100.80 & 100.70 & 100.90 & 99.97 & 98.46 \\
\hline Ag & $<0.3$ & $<0.3$ & $<0.3$ & $<0.3$ & $<0.3$ & $<0.3$ & $<0.3$ & $<0.3$ & $<0.3$ \\
\hline As & $<0.5$ & $<0.5$ & 1.5 & $<0.5$ & $<0.5$ & $<0.5$ & $<0.5$ & $<0.5$ & $<0.5$ \\
\hline $\mathrm{Au}$ & $<2$ & $<2$ & $<2$ & $<2$ & $<2$ & $<2$ & $<2$ & $<2$ & $<2$ \\
\hline $\mathrm{Ba}$ & 177 & 280 & 151 & 125 & 382 & 511 & 434 & 572 & 454 \\
\hline $\mathrm{Be}$ & 6 & 2 & 3 & 3 & 5 & 3 & 3 & 3 & 3 \\
\hline $\mathrm{Bi}$ & 0.2 & 0.6 & 1.3 & 1.7 & 0.7 & 1.2 & 0.2 & 0.3 & 0.6 \\
\hline $\mathrm{Cd}$ & $<0.5$ & $<0.5$ & $<0.5$ & $<0.5$ & $<0.5$ & $<0.5$ & $<0.5$ & $<0.5$ & $<0.5$ \\
\hline Co & $<1$ & 1.0 & $<1$ & $<1$ & 2.0 & 7.0 & 6.0 & 11.0 & 7.0 \\
\hline $\mathrm{Cr}$ & 9 & 17 & 19 & 20 & 14 & 41 & 25 & 49 & 32 \\
\hline Cs & 8.4 & 4.3 & 8.7 & 8.8 & 6.7 & 8.3 & 7.4 & 4.6 & 6.8 \\
\hline $\mathrm{Cu}$ & 2 & 1 & 1 & 1 & 6 & 17 & 6 & 13 & 3 \\
\hline $\mathrm{Ga}$ & 19 & 18 & 18 & 19 & 22 & 19 & 20 & 20 & 19 \\
\hline $\mathrm{Ge}$ & 2.5 & 1.7 & 2.4 & 2.5 & 1.8 & 1.6 & 2.3 & 2.0 & 1.9 \\
\hline $\mathrm{Hf}$ & 2.7 & 2.4 & 1.7 & 1.6 & 2.4 & 5.6 & 4.6 & 7.3 & 5.5 \\
\hline In & $<0.1$ & $<0.1$ & $<0.1$ & $<0.1$ & $<0.1$ & $<0.1$ & $<0.1$ & $<0.1$ & $<0.1$ \\
\hline Mo & $<2.0$ & $<2.0$ & $<2.0$ & $<2.0$ & $<2.0$ & $<2.0$ & $<2.0$ & $<2.0$ & $<2.0$ \\
\hline $\mathrm{Nb}$ & 21.6 & 10.3 & 8.5 & 14.7 & 11.2 & 9.9 & 14.0 & 16.4 & 9.9 \\
\hline $\mathrm{Ni}$ & 3 & 2 & 3 & 1 & 4 & 10 & 8 & 12 & 8 \\
\hline $\mathrm{Pb}$ & 29 & 38 & 24 & 24 & 39 & 19 & 21 & 21 & 20 \\
\hline $\mathrm{Rb}$ & 289 & 213 & 274 & 298 & 266 & 174 & 165 & 143 & 181 \\
\hline$S$ & 0.007 & 0.004 & 0.004 & 0.002 & 0.004 & 0.015 & 0.007 & 0.015 & 0.034 \\
\hline $\mathrm{Sb}$ & $<0.2$ & 0.4 & 0.3 & $<0.2$ & $<0.2$ & $<0.2$ & 0.6 & $<0.2$ & $<0.2$ \\
\hline $\mathrm{Sc}$ & 5.0 & 3.0 & 4.0 & 4.0 & 3.0 & 10.0 & 8.0 & 12.0 & 9.0 \\
\hline Sn & 13.0 & 6.0 & 9.0 & 11.0 & 10.0 & 5.0 & 5.0 & 4.0 & 6.0 \\
\hline $\mathrm{Sr}$ & 31 & 60 & 40 & 30 & 77 & 149 & 201 & 180 & 152 \\
\hline $\mathrm{Ta}$ & 3.26 & 1.28 & 2.36 & 2.86 & 1.78 & 1.59 & 1.55 & 1.47 & 1.51 \\
\hline Th & 19.90 & 11.90 & 11.00 & 9.20 & 11.80 & 18.20 & 20.20 & 14.30 & 19.30 \\
\hline $\mathrm{Tl}$ & 1.25 & 1.10 & 1.29 & 1.46 & 1.45 & 0.92 & 0.82 & 0.74 & 0.91 \\
\hline $\mathrm{U}$ & 7.38 & 4.78 & 5.88 & 3.78 & 3.79 & 4.17 & 4.09 & 3.43 & 5.66 \\
\hline $\mathrm{V}$ & 6 & 10 & 8 & 6 & 15 & 66 & 51 & 91 & 60 \\
\hline $\mathrm{W}$ & 2.9 & $<0.5$ & 1.2 & 2.7 & 1.3 & 2.8 & $<0.5$ & $<0.5$ & 2.0 \\
\hline $\mathrm{Y}$ & 57.8 & 23.8 & 22.5 & 18.6 & 15.2 & 41.5 & 35.4 & 36.7 & 35.1 \\
\hline $\mathrm{Zn}$ & 33 & 41 & 45 & 36 & 63 & 55 & 42 & 74 & 54 \\
\hline $\mathrm{Zr}$ & 77 & 77 & 57 & 46 & 83 & 241 & 178 & 323 & 236 \\
\hline $\mathrm{La}$ & 20.50 & 17.40 & 12.20 & 9.68 & 20.50 & 45.30 & 36.20 & 33.30 & 30.90 \\
\hline $\mathrm{Ce}$ & 37.20 & 37.70 & 26.90 & 20.20 & 43.20 & 80.50 & 74.60 & 78.10 & 66.80 \\
\hline $\operatorname{Pr}$ & 5.48 & 4.29 & 3.18 & 2.35 & 4.96 & 10.80 & 8.17 & 8.58 & 7.69 \\
\hline $\mathrm{Nd}$ & 20.80 & 16.70 & 11.90 & 8.86 & 18.70 & 40.70 & 31.00 & 34.30 & 28.70 \\
\hline $\mathrm{Sm}$ & 5.45 & 4.14 & 3.29 & 2.44 & 4.42 & 8.21 & 6.19 & 7.20 & 6.09 \\
\hline $\mathrm{Eu}$ & 0.46 & 0.54 & 0.37 & 0.26 & 0.73 & 1.20 & 1.04 & 1.63 & 1.12 \\
\hline $\mathrm{Gd}$ & 6.49 & 4.45 & 3.08 & 2.79 & 3.85 & 7.15 & 6.18 & 6.78 & 5.58 \\
\hline $\mathrm{Tb}$ & 1.25 & 0.80 & 0.63 & 0.53 & 0.52 & 1.15 & 0.98 & 1.10 & 0.94 \\
\hline Dy & 8.27 & 4.34 & 3.78 & 3.10 & 2.65 & 6.91 & 5.58 & 6.30 & 5.66 \\
\hline Ho & 1.65 & 0.72 & 0.68 & 0.56 & 0.44 & 1.32 & 1.07 & 1.24 & 1.09 \\
\hline $\mathrm{Er}$ & 5.23 & 1.95 & 1.91 & 1.57 & 1.25 & 3.94 & 3.18 & 3.32 & 3.18 \\
\hline $\mathrm{Tm}$ & 0.93 & 0.27 & 0.32 & 0.26 & 0.19 & 0.59 & 0.51 & 0.53 & 0.50 \\
\hline $\mathrm{Yb}$ & 6.44 & 1.65 & 2.05 & 1.67 & 1.13 & 3.51 & 3.34 & 3.48 & 3.22 \\
\hline $\mathrm{Lu}$ & 0.96 & 0.23 & 0.26 & 0.24 & 0.16 & 0.51 & 0.49 & 0.52 & 0.44 \\
\hline
\end{tabular}


APPENDIX B. Continued.

\begin{tabular}{|c|c|c|c|c|c|c|c|c|c|}
\hline $\begin{array}{l}\text { Sample \# } \\
\text { Pluton } \\
\text { Age }\end{array}$ & $\begin{array}{c}\text { RS-2 } \\
\text { Redstone Mtn. } \\
\text { late Silurian - } \\
\text { Early Devonian }\end{array}$ & $\begin{array}{c}\text { RS-5 } \\
\text { Redstone Mtn. } \\
\text { late Silurian - } \\
\text { Early Devonian }\end{array}$ & $\begin{array}{c}\text { RS-6 } \\
\text { Redstone Mtn. } \\
\text { late Silurian - } \\
\text { Early Devonian }\end{array}$ & $\begin{array}{c}\text { RS-7 } \\
\text { Redstone Mtn. } \\
\text { late Silurian - } \\
\text { Early Devonian }\end{array}$ & $\begin{array}{c}\text { RS-8 } \\
\text { Redstone Mtn. } \\
\text { late Silurian - } \\
\text { Early Devonian }\end{array}$ & $\begin{array}{c}\text { TD-11-3 } \\
\text { Redstone Mtn? } \\
\text { late Silurian - } \\
\text { Early Devonian }\end{array}$ & $\begin{array}{l}\text { 11-SHM-18 } \\
\text { Nashwaak } \\
\text { late Silurian }\end{array}$ & $\begin{array}{l}\text { 11-SHM-3 } \\
\text { Nashwaak } \\
\text { late Silurian }\end{array}$ & $\begin{array}{c}\text { 11-SHM-10 } \\
\text { Nashwaak } \\
\text { late Silurian }\end{array}$ \\
\hline $\mathrm{SiO}_{2}$ & 76.33 & 78.38 & 74.67 & 71.75 & 75.23 & 72.92 & 74.04 & 64.68 & 74.50 \\
\hline $\mathrm{TiO}_{2}$ & 0.14 & 0.12 & 0.21 & 0.39 & 0.13 & 0.25 & 0.20 & 0.98 & 0.15 \\
\hline $\mathrm{Al}_{2} \mathrm{O}_{3}$ & 11.51 & 12.12 & 12.23 & 13.57 & 12.20 & 12.88 & 13.76 & 15.28 & 14.47 \\
\hline $\mathrm{Fe}_{2} \mathrm{O}_{3}$ & 2.16 & 1.87 & 1.70 & 3.40 & 2.14 & 2.95 & 1.80 & 5.91 & 1.43 \\
\hline $\mathrm{MnO}$ & 0.01 & 0.03 & 0.02 & 0.07 & 0.02 & 0.10 & 0.05 & 0.09 & 0.04 \\
\hline $\mathrm{MgO}$ & 0.05 & 0.11 & 0.28 & 0.49 & 0.07 & 0.26 & 0.39 & 1.56 & 0.25 \\
\hline $\mathrm{CaO}$ & 0.51 & 0.52 & 0.59 & 1.09 & 0.65 & 0.07 & 1.13 & 3.09 & 0.51 \\
\hline $\mathrm{Na}_{2} \mathrm{O}$ & 3.42 & 6.38 & 2.79 & 5.15 & 3.64 & 1.43 & 3.14 & 3.13 & 3.21 \\
\hline $\mathrm{K}_{2} \mathrm{O}$ & 4.41 & 0.10 & 5.40 & 2.07 & 4.57 & 6.13 & 4.42 & 3.02 & 4.71 \\
\hline $\mathrm{P}_{2} \mathrm{O}_{5}$ & 0.01 & $<0.01$ & 0.03 & 0.14 & $<0.01$ & 0.02 & 0.14 & 0.29 & 0.16 \\
\hline LOI & 0.50 & 0.63 & 0.80 & 1.16 & 0.61 & 1.77 & 1.68 & 0.90 & 0.90 \\
\hline TOTAL & 99.05 & 100.30 & 98.72 & 99.28 & 99.24 & 98.79 & 100.70 & 98.94 & 100.30 \\
\hline $\mathrm{Ag}$ & $<0.5$ & $<0.5$ & $<0.5$ & $<0.5$ & $<0.5$ & $<0.5$ & $<0.3$ & $<0.3$ & 0.4 \\
\hline As & 7.0 & 26.0 & 17.0 & 15.0 & 13.0 & 35.0 & 2.3 & $<0.5$ & $<0.5$ \\
\hline $\mathrm{Au}$ & $<1$ & $<1$ & $<1$ & $<1$ & $<1$ & $<1$ & $<2$ & $<2$ & $<2$ \\
\hline $\mathrm{Ba}$ & 860 & 19 & 584 & 495 & 913 & 153 & 388 & 511 & 297 \\
\hline $\mathrm{Be}$ & 2 & 2 & 3 & 4 & 3 & 6 & 2 & 3 & 6 \\
\hline $\mathrm{Bi}$ & 0.4 & 1.0 & 0.8 & 1.5 & 0.6 & 31.8 & 0.2 & 0.3 & 0.3 \\
\hline $\mathrm{Cd}$ & $<0.5$ & $<0.5$ & $<0.5$ & $<0.5$ & $<0.5$ & $<0.5$ & $<0.5$ & $<0.5$ & $<0.5$ \\
\hline Co & 1.9 & $<0.1$ & $<0.1$ & 3.8 & $<0.1$ & 2.8 & 2.0 & 11.0 & 1.0 \\
\hline $\mathrm{Cr}$ & 10 & 18 & 21 & 14 & 16 & 12 & 18 & 26 & 9 \\
\hline Cs & 1.6 & 0.2 & 1.4 & 0.4 & 0.5 & 9.8 & 6.1 & 6.3 & 7.8 \\
\hline $\mathrm{Cu}$ & 2 & 2 & 1 & 3 & 6 & 115 & 3 & 16 & 1 \\
\hline $\mathrm{Ga}$ & 17 & 22 & 15 & 19 & 21 & 26 & 18 & 22 & 20 \\
\hline $\mathrm{Ge}$ & 2.3 & 1.9 & 2.2 & 2.3 & 2.3 & 3.8 & 1.9 & 1.8 & 2.5 \\
\hline $\mathrm{Hf}$ & 7.3 & 11.1 & 4.5 & 8.2 & 8.9 & 5.2 & 2.9 & 5.3 & 2.3 \\
\hline In & $<0.1$ & $<0.1$ & $<0.1$ & $<0.1$ & $<0.1$ & 0.2 & $<0.1$ & $<0.1$ & $<0.1$ \\
\hline Mo & $<2$ & $<2$ & $<2$ & $<2$ & $<2$ & 17.0 & $<2.0$ & $<2.0$ & $<2.0$ \\
\hline $\mathrm{Nb}$ & 19.2 & 33.0 & 11.3 & 18.2 & 26.1 & 29.7 & 11.5 & 15.0 & 15.7 \\
\hline $\mathrm{Ni}$ & 4 & 4 & 4 & 5 & 3 & 3 & 5 & 12 & 2 \\
\hline $\mathrm{Pb}$ & $<5$ & $<5$ & 12 & $<5$ & $<5$ & 19 & 25 & 11 & 23 \\
\hline $\mathrm{Rb}$ & 127 & 4 & 186 & 58 & 128 & 553 & 208 & 167 & 251 \\
\hline S & 0.003 & 0.004 & 0.003 & 0.005 & 0.004 & 0.004 & 0.005 & 0.026 & 0.003 \\
\hline $\mathrm{Sb}$ & 0.2 & $<0.1$ & $<0.1$ & 0.1 & $<0.1$ & 0.2 & $<0.2$ & $<0.2$ & 0.2 \\
\hline $\mathrm{Sc}$ & 5.3 & 1.4 & 4.7 & 8.6 & 4.0 & 6.0 & 4.0 & 12.0 & 4.0 \\
\hline Sn & 4.0 & 10.0 & 7.0 & 5.0 & 7.0 & 131.0 & 7.0 & 4.0 & 10.0 \\
\hline $\mathrm{Sr}$ & 66 & 59 & 117 & 147 & 81 & 36 & 78 & 187 & 49 \\
\hline $\mathrm{Ta}$ & 1.63 & 2.58 & 1.45 & 1.48 & 2.06 & 3.80 & 2.03 & 1.48 & 3.19 \\
\hline Th & 18.40 & 24.00 & 27.30 & 18.80 & 25.90 & 50.10 & 15.40 & 5.00 & 13.20 \\
\hline $\mathrm{Tl}$ & 0.44 & $<0.05$ & 1.00 & 0.28 & 0.59 & 2.95 & 1.10 & 0.82 & 1.09 \\
\hline $\mathrm{U}$ & 3.77 & 6.69 & 6.33 & 4.62 & 6.62 & 24.70 & 2.73 & 3.65 & 3.88 \\
\hline $\mathrm{V}$ & $<5$ & $<5$ & 12 & 13 & $<5$ & 13 & 18 & 104 & 12 \\
\hline $\mathrm{W}$ & $<1$ & $<1$ & $<1$ & $<1$ & $<1$ & 34.0 & $<0.5$ & 0.8 & 4.0 \\
\hline $\mathrm{Y}$ & 39.0 & 73.0 & 34.0 & 47.0 & 79.0 & 38.0 & 23.0 & 17.8 & 25.3 \\
\hline $\mathrm{Zn}$ & 11 & 17 & 17 & 28 & 10 & 23 & 35 & 79 & 32 \\
\hline $\mathrm{Zr}$ & 243 & 324 & 134 & 352 & 265 & 185 & 101 & 241 & 73 \\
\hline $\mathrm{La}$ & 41.00 & 57.60 & 38.80 & 58.00 & 88.10 & 40.90 & 23.80 & 26.40 & 17.40 \\
\hline $\mathrm{Ce}$ & 94.00 & 138.00 & 78.60 & 124.00 & 156.00 & 87.50 & 47.30 & 52.10 & 33.10 \\
\hline $\operatorname{Pr}$ & 9.39 & 14.80 & 8.54 & 13.50 & 20.10 & 10.70 & 5.06 & 5.99 & 3.81 \\
\hline $\mathrm{Nd}$ & 34.90 & 56.60 & 30.10 & 50.30 & 75.10 & 38.30 & 18.90 & 24.10 & 14.40 \\
\hline $\mathrm{Sm}$ & 7.43 & 12.90 & 6.13 & 10.10 & 15.70 & 9.09 & 4.08 & 5.02 & 3.46 \\
\hline $\mathrm{Eu}$ & 0.95 & 0.76 & 0.83 & 2.28 & 1.61 & 0.49 & 0.61 & 1.40 & 0.41 \\
\hline $\mathrm{Gd}$ & 6.72 & 12.20 & 6.03 & 9.02 & 14.30 & 7.30 & 3.98 & 4.68 & 3.62 \\
\hline $\mathrm{Tb}$ & 1.17 & 2.31 & 1.01 & 1.48 & 2.49 & 1.34 & 0.63 & 0.55 & 0.68 \\
\hline Dy & 7.20 & 14.30 & 6.53 & 8.88 & 15.20 & 7.90 & 3.68 & 2.63 & 3.98 \\
\hline Ho & 1.52 & 2.97 & 1.29 & 1.78 & 3.07 & 1.48 & 0.69 & 0.51 & 0.76 \\
\hline Er & 4.40 & 8.84 & 3.84 & 5.26 & 8.65 & 4.29 & 2.09 & 1.59 & 2.16 \\
\hline $\mathrm{Tm}$ & 0.70 & 1.40 & 0.64 & 0.81 & 1.34 & 0.71 & 0.32 & 0.25 & 0.32 \\
\hline $\mathrm{Yb}$ & 4.89 & 8.80 & 4.23 & 5.50 & 8.87 & 4.96 & 1.99 & 1.55 & 2.13 \\
\hline $\mathrm{Lu}$ & 0.78 & 1.44 & 0.63 & 0.85 & 1.38 & 0.78 & 0.28 & 0.24 & 0.32 \\
\hline
\end{tabular}


APPENDIX B. Continued.

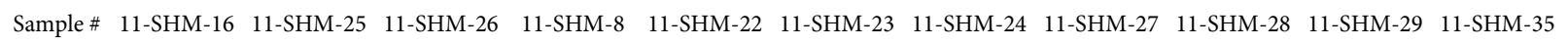
Pluton Nashwaak Nashwaak Nashwaak Nashwaak Nashwaak Nashwaak Nashwaak Nashwaak Nashwaak Nashwaak Nashwaak

Age late Silurian late Silurian late Silurian late Silurian late Silurian late Silurian late Silurian late Silurian late Silurian late Silurian late Silurian

\begin{tabular}{|c|c|c|c|c|c|c|c|c|c|c|c|}
\hline $\mathrm{SiO}_{2}$ & 76.05 & 78.21 & 76.83 & 75.50 & 72.67 & 73.83 & 78.62 & 78.10 & 72.43 & 73.59 & 72.20 \\
\hline $\mathrm{TiO}_{2}$ & 0.06 & 0.20 & 0.24 & 0.05 & 0.34 & 0.10 & 0.22 & 0.10 & 0.25 & 0.14 & 0.16 \\
\hline $\mathrm{Al}_{2} \mathrm{O}_{3}$ & 14.17 & 12.16 & 12.41 & 14.70 & 13.83 & 13.71 & 11.73 & 11.69 & 14.19 & 14.10 & 14.16 \\
\hline $\mathrm{Fe}_{2} \mathrm{O}_{3}$ & 0.97 & 0.98 & 1.65 & 0.71 & 2.80 & 1.17 & 1.41 & 1.16 & 2.08 & 1.50 & 1.55 \\
\hline $\mathrm{MnO}$ & 0.08 & 0.01 & 0.02 & 0.02 & 0.06 & 0.05 & 0.01 & 0.03 & 0.06 & 0.03 & 0.04 \\
\hline $\mathrm{MgO}$ & 0.13 & 0.21 & 0.21 & 0.12 & 0.56 & 0.18 & 0.17 & 0.05 & 0.54 & 0.34 & 0.28 \\
\hline $\mathrm{CaO}$ & 0.33 & 0.51 & 0.77 & 0.42 & 1.45 & 0.46 & 0.69 & 0.48 & 1.10 & 0.74 & 0.69 \\
\hline $\mathrm{Na}_{2} \mathrm{O}$ & 3.37 & 3.78 & 3.17 & 3.91 & 3.18 & 3.12 & 4.38 & 3.19 & 3.26 & 3.11 & 3.18 \\
\hline $\mathrm{K}_{2} \mathrm{O}$ & 4.43 & 3.91 & 4.80 & 4.22 & 4.40 & 4.52 & 2.77 & 4.48 & 4.22 & 4.80 & 5.05 \\
\hline $\mathrm{P}_{2} \mathrm{O}_{5}$ & 0.21 & 0.04 & 0.03 & 0.27 & 0.11 & 0.22 & 0.05 & $<0.01$ & 0.16 & 0.28 & 0.18 \\
\hline LOI & 0.89 & 0.42 & 0.30 & 0.85 & 0.56 & 0.88 & 0.39 & 0.31 & 0.74 & 0.82 & 0.66 \\
\hline TOTAL & 100.70 & 100.40 & 100.40 & 100.80 & 99.95 & 98.25 & 100.40 & 99.61 & 99.01 & 99.45 & 98.15 \\
\hline Ag & 0.3 & 0.4 & 0.4 & $<0.3$ & $<0.3$ & $<0.3$ & $<0.3$ & $<0.3$ & 0.3 & $<0.3$ & 0.6 \\
\hline As & $<0.5$ & $<0.5$ & $<0.5$ & 4.6 & $<0.5$ & $<0.5$ & $<0.5$ & $<0.5$ & $<0.5$ & $<0.5$ & 1.8 \\
\hline $\mathrm{Au}$ & $<2$ & $<2$ & $<2$ & $<2$ & $<2$ & $<2$ & $<2$ & $<2$ & $<2$ & $<2$ & $<2$ \\
\hline $\mathrm{Ba}$ & 42 & 221 & 327 & 78 & 384 & 135 & 294 & 22 & 353 & 278 & 240 \\
\hline $\mathrm{Be}$ & 5 & 3 & 4 & 4 & 3 & 4 & 2 & 3 & 5 & 10 & 4 \\
\hline $\mathrm{Bi}$ & 3.0 & $<0.1$ & $<0.1$ & 0.1 & 1.0 & 2.8 & $<0.1$ & $<0.1$ & 2.6 & 1.2 & 2.2 \\
\hline $\mathrm{Cd}$ & $<0.5$ & $<0.5$ & $<0.5$ & $<0.5$ & $<0.5$ & $<0.5$ & $<0.5$ & $<0.5$ & $<0.5$ & $<0.5$ & $<0.5$ \\
\hline Co & $<1$ & $<1$ & 2.0 & $<1$ & 3.0 & $<1$ & $<1$ & $<1$ & 3.0 & 1.0 & 2.0 \\
\hline $\mathrm{Cr}$ & $<5$ & $<5$ & 13 & 28 & 20 & 8 & 17 & 14 & 16 & 16 & 18 \\
\hline Cs & 8.5 & 1.7 & 5.6 & 5.4 & 9.6 & 10.9 & 0.7 & 3.4 & 11.3 & 9.6 & 11.8 \\
\hline $\mathrm{Cu}$ & 2 & 27 & 2 & 4 & 4 & $<1$ & 3 & 1 & 3 & 3 & 3 \\
\hline $\mathrm{Ga}$ & 20 & 16 & 17 & 19 & 21 & 18 & 16 & 17 & 19 & 18 & 20 \\
\hline $\mathrm{Ge}$ & 3.2 & 2.1 & 1.9 & 3.4 & 2.6 & 3.1 & 1.9 & 2.0 & 2.2 & 2.5 & 2.7 \\
\hline $\mathrm{Hf}$ & 1.0 & 3.9 & 5.2 & 0.7 & 3.3 & 1.4 & 4.5 & 3.8 & 2.7 & 1.9 & 2.1 \\
\hline In & $<0.1$ & $<0.1$ & $<0.1$ & $<0.1$ & $<0.1$ & $<0.1$ & $<0.1$ & $<0.1$ & $<0.1$ & $<0.1$ & $<0.1$ \\
\hline Mo & $<2.0$ & $<2.0$ & $<2.0$ & $<2.0$ & $<2.0$ & $<2.0$ & $<2.0$ & $<2.0$ & $<2.0$ & $<2.0$ & $<2.0$ \\
\hline $\mathrm{Nb}$ & 13.7 & 8.3 & 8.9 & 11.7 & 15.4 & 10.4 & 9.6 & 5.7 & 7.5 & 11.9 & 14.1 \\
\hline $\mathrm{Ni}$ & 2 & 3 & 3 & 2 & 5 & 3 & 3 & 1 & 5 & 4 & 4 \\
\hline $\mathrm{Pb}$ & 18 & 8 & 15 & 18 & 30 & 33 & $<5$ & 23 & 25 & 38 & 28 \\
\hline $\mathrm{Rb}$ & 232 & 141 & 219 & 209 & 214 & 252 & 85 & 277 & 231 & 220 & 252 \\
\hline $\mathrm{S}$ & 0.002 & 0.006 & 0.004 & 0.004 & 0.007 & 0.007 & 0.007 & 0.004 & 0.005 & 0.008 & 0.003 \\
\hline $\mathrm{Sb}$ & 0.4 & $<0.2$ & $<0.2$ & 0.5 & $<0.2$ & $<0.2$ & $<0.2$ & $<0.2$ & 0.5 & 0.4 & 0.6 \\
\hline $\mathrm{Sc}$ & 5.0 & 4.0 & 5.0 & 4.0 & 8.0 & 5.0 & 4.0 & 4.0 & 6.0 & 4.0 & 5.0 \\
\hline $\mathrm{Sn}$ & 19.0 & 6.0 & 5.0 & 23.0 & 7.0 & 20.0 & 9.0 & 5.0 & 10.0 & 13.0 & 11.0 \\
\hline $\mathrm{Sr}$ & 18 & 55 & 41 & 24 & 86 & 32 & 63 & 15 & 82 & 54 & 62 \\
\hline $\mathrm{Ta}$ & 3.43 & 0.84 & 2.42 & 2.51 & 1.95 & 2.26 & 1.14 & 0.92 & 2.42 & 2.79 & 2.80 \\
\hline Th & 2.30 & 27.00 & 33.70 & 2.50 & 18.50 & 2.90 & 30.10 & 40.60 & 11.50 & 6.80 & 12.20 \\
\hline $\mathrm{Tl}$ & 1.12 & 0.50 & 0.94 & 0.99 & 0.98 & 1.12 & 0.32 & 1.20 & 1.15 & 1.03 & 1.23 \\
\hline $\mathrm{U}$ & 4.33 & 3.37 & 8.48 & 5.79 & 2.43 & 2.66 & 4.46 & 5.50 & 3.91 & 3.53 & 3.72 \\
\hline $\mathrm{V}$ & 5 & 10 & 16 & $<5$ & 31 & 8 & 13 & $<5$ & 24 & 9 & 13 \\
\hline W & 3.3 & 0.6 & $<0.5$ & 5.3 & $<0.5$ & 3.3 & $<0.5$ & 0.7 & $<0.5$ & $<0.5$ & 1.0 \\
\hline $\mathrm{Y}$ & 7.3 & 31.1 & 43.1 & 6.1 & 31.4 & 11.9 & 45.8 & 41.5 & 21.7 & 19.1 & 25.9 \\
\hline $\mathrm{Zn}$ & 20 & 9 & 13 & 13 & 51 & 41 & 6 & 20 & 47 & 47 & 38 \\
\hline $\mathrm{Zr}$ & 24 & 129 & 166 & 15 & 133 & 46 & 144 & 98 & 101 & 60 & 72 \\
\hline $\mathrm{La}$ & 2.74 & 32.90 & 37.50 & 2.05 & 30.40 & 6.25 & 20.90 & 10.60 & 22.30 & 11.20 & 17.90 \\
\hline $\mathrm{Ce}$ & 5.35 & 66.60 & 71.70 & 3.46 & 63.90 & 12.80 & 73.90 & 60.80 & 44.20 & 23.00 & 37.90 \\
\hline $\operatorname{Pr}$ & 0.59 & 7.31 & 8.65 & 0.48 & 7.13 & 1.44 & 6.25 & 2.56 & 4.95 & 2.56 & 4.07 \\
\hline $\mathrm{Nd}$ & 2.15 & 26.60 & 31.50 & 1.79 & 27.30 & 5.59 & 25.10 & 9.71 & 18.30 & 9.69 & 14.30 \\
\hline $\mathrm{Sm}$ & 0.73 & 5.46 & 6.19 & 0.65 & 6.06 & 1.28 & 5.70 & 2.33 & 4.13 & 2.43 & 3.40 \\
\hline $\mathrm{Eu}$ & 0.09 & 0.43 & 0.63 & 0.13 & 0.69 & 0.26 & 0.44 & 0.13 & 0.64 & 0.51 & 0.46 \\
\hline $\mathrm{Gd}$ & 0.84 & 5.19 & 5.61 & 0.88 & 5.89 & 1.47 & 6.37 & 3.13 & 3.81 & 3.06 & 3.52 \\
\hline $\mathrm{Tb}$ & 0.20 & 0.81 & 0.99 & 0.17 & 0.91 & 0.30 & 1.10 & 0.65 & 0.66 & 0.55 & 0.67 \\
\hline Dy & 1.24 & 4.77 & 6.12 & 1.01 & 4.89 & 1.87 & 7.11 & 5.01 & 3.71 & 3.16 & 4.01 \\
\hline Ho & 0.23 & 0.93 & 1.21 & 0.18 & 0.90 & 0.33 & 1.47 & 1.16 & 0.69 & 0.55 & 0.75 \\
\hline Er & 0.66 & 2.87 & 4.05 & 0.51 & 2.57 & 1.00 & 4.31 & 3.83 & 2.03 & 1.44 & 2.22 \\
\hline $\mathrm{Tm}$ & 0.12 & 0.47 & 0.72 & 0.09 & 0.40 & 0.18 & 0.69 & 0.64 & 0.32 & 0.21 & 0.35 \\
\hline $\mathrm{Yb}$ & 0.87 & 3.01 & 5.10 & 0.63 & 2.57 & 1.23 & 4.70 & 4.26 & 2.01 & 1.28 & 2.19 \\
\hline $\mathrm{Lu}$ & 0.13 & 0.42 & 0.79 & 0.09 & 0.37 & 0.16 & 0.67 & 0.61 & 0.27 & 0.17 & 0.32 \\
\hline
\end{tabular}


APPENDIX B. Continued.

\begin{tabular}{|c|c|c|c|c|c|c|c|c|c|c|}
\hline $\begin{array}{l}\text { Sample \# } \\
\text { Pluton } \\
\text { Age }\end{array}$ & $\begin{array}{c}\text { 11-SHM-36 } \\
\text { Nashwaak } \\
\text { late Silurian }\end{array}$ & $\begin{array}{c}\text { 11-SHM-49 } \\
\text { Nashwaak } \\
\text { late Silurian }\end{array}$ & $\begin{array}{c}\text { 12-SHM-20 } \\
\text { Bogan Brook } \\
\text { late Silurian }\end{array}$ & $\begin{array}{c}\text { 11-SHM-6 } \\
\text { Bogan Brook } \\
\text { late Silurian }\end{array}$ & $\begin{array}{c}\text { 11-SHM-47 } \\
\text { Bogan Brook } \\
\text { late Silurian }\end{array}$ & $\begin{array}{l}\text { 11-SHM-33 } \\
\text { McKiel Lake } \\
\text { Middle } \\
\text { Ordovician }\end{array}$ & $\begin{array}{l}\text { 11-SHM-17 } \\
\text { McKiel Lake } \\
\text { Middle } \\
\text { Ordovician }\end{array}$ & $\begin{array}{l}\text { 11-SHM-15 } \\
\text { McKiel Lake } \\
\text { Middle } \\
\text { Ordovician }\end{array}$ & $\begin{array}{l}\text { 12-SHM-8 } \\
\text { McKiel Lake } \\
\text { Middle } \\
\text { Ordovician }\end{array}$ & $\begin{array}{c}\text { 12-SHM-9 } \\
\text { McKiel Lake } \\
\text { Middle } \\
\text { Ordovician }\end{array}$ \\
\hline $\mathrm{SiO}_{2}$ & 72.47 & 73.24 & 68.44 & 66.89 & 68.42 & 75.49 & 68.82 & 70.29 & 71.77 & 70.34 \\
\hline $\mathrm{TiO}_{2}$ & 0.14 & 0.17 & 0.58 & 0.75 & 0.70 & 0.32 & 0.80 & 0.69 & 0.51 & 0.23 \\
\hline $\mathrm{Al}_{2} \mathrm{O}_{3}$ & 14.29 & 14.23 & 14.84 & 15.53 & 14.92 & 12.67 & 13.87 & 14.17 & 13.00 & 14.62 \\
\hline $\mathrm{Fe}_{2} \mathrm{O}_{3}$ & 1.42 & 1.73 & 3.89 & 4.27 & 3.96 & 2.07 & 4.94 & 4.13 & 3.15 & 2.58 \\
\hline $\mathrm{MnO}$ & 0.05 & 0.05 & 0.06 & 0.08 & 0.09 & 0.05 & 0.09 & 0.08 & 0.06 & 0.04 \\
\hline $\mathrm{MgO}$ & 0.34 & 0.30 & 0.93 & 1.51 & 1.33 & 0.43 & 1.12 & 1.01 & 0.68 & 0.42 \\
\hline $\mathrm{CaO}$ & 0.69 & 0.63 & 2.60 & 3.68 & 3.33 & 0.94 & 2.69 & 1.87 & 1.74 & 2.29 \\
\hline $\mathrm{Na}_{2} \mathrm{O}$ & 3.37 & 3.00 & 3.29 & 3.42 & 3.11 & 3.09 & 3.02 & 2.75 & 2.85 & 3.92 \\
\hline $\mathrm{K}_{2} \mathrm{O}$ & 4.68 & 4.83 & 3.76 & 2.98 & 2.71 & 4.23 & 3.36 & 3.97 & 3.84 & 2.52 \\
\hline $\mathrm{P}_{2} \mathrm{O}_{5}$ & 0.30 & 0.16 & 0.17 & 0.15 & 0.15 & 0.07 & 0.21 & 0.15 & 0.12 & 0.09 \\
\hline LOI & 0.78 & 0.92 & 1.15 & 0.93 & 0.67 & 0.87 & 0.84 & 0.86 & 0.92 & 0.93 \\
\hline TOTAL & 98.53 & 99.24 & 99.70 & 100.20 & 99.39 & 100.20 & 99.74 & 99.98 & 98.64 & 97.98 \\
\hline $\mathrm{Ag}$ & $<0.3$ & $<0.3$ & 0.5 & $<0.3$ & $<0.3$ & 0.3 & 0.3 & $<0.3$ & $<0.3$ & 0.4 \\
\hline As & $<0.5$ & 2.8 & $<0.5$ & $<0.5$ & $<0.5$ & $<0.5$ & 1.2 & $<0.5$ & $<0.5$ & $<0.5$ \\
\hline $\mathrm{Au}$ & $<2$ & $<2$ & $<2$ & $<2$ & $<2$ & $<2$ & $<2$ & $<2$ & $<2$ & $<2$ \\
\hline $\mathrm{Ba}$ & 258 & 248 & 533 & 460 & 348 & 415 & 622 & 517 & 501 & 453 \\
\hline $\mathrm{Be}$ & 7 & 4 & 3 & 3 & 3 & 2 & 2 & 2 & 3 & 2 \\
\hline $\mathrm{Bi}$ & 2.5 & 1.0 & 0.2 & 0.1 & 0.7 & 0.2 & 0.2 & 0.2 & $<0.1$ & $<0.1$ \\
\hline $\mathrm{Cd}$ & $<0.5$ & $<0.5$ & $<0.5$ & $<0.5$ & $<0.5$ & $<0.5$ & $<0.5$ & $<0.5$ & $<0.5$ & $<0.5$ \\
\hline Co & 1.0 & 2.0 & 6.0 & 10.0 & 9.0 & 3.0 & 9.0 & 7.0 & 5.0 & 3.0 \\
\hline $\mathrm{Cr}$ & 9 & 20 & 25 & 31 & 26 & 20 & 16 & 34 & 33 & $<5$ \\
\hline Cs & 10.9 & 11.6 & 8.5 & 5.9 & 9.7 & 2.9 & 5.6 & 6.5 & 1.7 & 1.9 \\
\hline $\mathrm{Cu}$ & 4 & 15 & 9 & 10 & 27 & 3 & 16 & 3 & 4 & 1 \\
\hline $\mathrm{Ga}$ & 19 & 17 & 20 & 20 & 18 & 16 & 19 & 17 & 19 & 18 \\
\hline $\mathrm{Ge}$ & 2.5 & 2.2 & 2.0 & 1.7 & 2.3 & 1.9 & 1.8 & 2.3 & 1.7 & 1.6 \\
\hline $\mathrm{Hf}$ & 1.4 & 2.4 & 5.7 & 4.3 & 2.7 & 3.6 & 7.6 & 5.7 & 4.6 & 4.9 \\
\hline In & $<0.1$ & $<0.1$ & $<0.1$ & $<0.1$ & $<0.1$ & $<0.1$ & $<0.1$ & $<0.1$ & $<0.1$ & $<0.1$ \\
\hline Mo & $<2.0$ & $<2.0$ & $<2.0$ & $<2.0$ & $<2.0$ & $<2.0$ & $<2.0$ & $<2.0$ & $<2.0$ & $<2.0$ \\
\hline $\mathrm{Nb}$ & 7.7 & 12.2 & 9.3 & 12.3 & 7.5 & 10.3 & 14.6 & 13.0 & 10.0 & 7.8 \\
\hline $\mathrm{Ni}$ & 4 & 4 & 7 & 10 & 9 & 5 & 11 & 13 & 9 & 3 \\
\hline $\mathrm{Pb}$ & 37 & 28 & 25 & 18 & 13 & 23 & 14 & 19 & 20 & 15 \\
\hline $\mathrm{Rb}$ & 244 & 224 & 178 & 140 & 120 & 181 & 135 & 145 & 144 & 86 \\
\hline$S$ & 0.003 & 0.005 & 0.013 & 0.017 & 0.028 & 0.005 & 0.011 & 0.010 & 0.009 & 0.013 \\
\hline $\mathrm{Sb}$ & 0.7 & 0.7 & $<0.2$ & $<0.2$ & 0.5 & $<0.2$ & $<0.2$ & 0.3 & $<0.2$ & 0.2 \\
\hline Sc & 4.0 & 5.0 & 10.0 & 11.0 & 17.0 & 6.0 & 13.0 & 12.0 & 7.0 & 3.0 \\
\hline Sn & 17.0 & 10.0 & 4.0 & 4.0 & 3.0 & 3.0 & 3.0 & 2.0 & 7.0 & 3.0 \\
\hline $\mathrm{Sr}$ & 49 & 56 & 168 & 247 & 206 & 100 & 139 & 150 & 122 & 231 \\
\hline $\mathrm{Ta}$ & 2.94 & 1.94 & 1.35 & 1.39 & 0.47 & 1.34 & 1.15 & 1.00 & 1.09 & 0.76 \\
\hline Th & 6.00 & 12.70 & 14.80 & 14.90 & 9.80 & 17.10 & 13.40 & 9.80 & 11.30 & 9.80 \\
\hline $\mathrm{Tl}$ & 1.18 & 1.17 & 0.86 & 0.75 & 0.56 & 1.00 & 0.73 & 0.76 & 0.65 & 0.45 \\
\hline $\mathrm{U}$ & 3.18 & 5.30 & 4.01 & 6.97 & 3.34 & 5.46 & 2.59 & 1.13 & 1.62 & 1.83 \\
\hline $\mathrm{V}$ & 10 & 13 & 55 & 87 & 77 & 25 & 73 & 61 & 45 & 15 \\
\hline $\mathrm{W}$ & 1.7 & 1.1 & $<0.5$ & 0.5 & $<0.5$ & $<0.5$ & $<0.5$ & 0.8 & $<0.5$ & $<0.5$ \\
\hline $\mathrm{Y}$ & 18.1 & 23.2 & 33.4 & 24.8 & 9.2 & 32.8 & 39.7 & 14.8 & 14.5 & 16.3 \\
\hline $\mathrm{Zn}$ & 49 & 42 & 50 & 50 & 39 & 27 & 67 & 63 & 41 & 47 \\
\hline $\mathrm{Zr}$ & 55 & 76 & 248 & 174 & 111 & 132 & 327 & 235 & 199 & 186 \\
\hline $\mathrm{La}$ & 10.50 & 18.00 & 40.50 & 29.00 & 23.40 & 22.30 & 22.00 & 29.70 & 33.50 & 29.60 \\
\hline $\mathrm{Ce}$ & 21.50 & 39.60 & 78.50 & 58.80 & 40.40 & 55.60 & 61.80 & 61.50 & 69.40 & 58.10 \\
\hline $\operatorname{Pr}$ & 2.55 & 4.64 & 9.34 & 6.26 & 4.02 & 5.09 & 5.72 & 6.76 & 7.83 & 6.66 \\
\hline $\mathrm{Nd}$ & 9.99 & 16.80 & 35.00 & 24.10 & 13.00 & 18.70 & 24.30 & 27.30 & 29.70 & 24.50 \\
\hline $\mathrm{Sm}$ & 2.40 & 4.21 & 6.81 & 4.89 & 2.37 & 4.07 & 6.02 & 5.22 & 5.27 & 4.13 \\
\hline $\mathrm{Eu}$ & 0.52 & 0.52 & 1.28 & 1.09 & 0.73 & 0.51 & 1.44 & 1.21 & 1.01 & 0.99 \\
\hline $\mathrm{Gd}$ & 2.37 & 4.02 & 5.83 & 4.65 & 2.25 & 4.46 & 7.06 & 4.58 & 3.86 & 3.69 \\
\hline $\mathrm{Tb}$ & 0.50 & 0.70 & 0.94 & 0.68 & 0.31 & 0.74 & 1.12 & 0.59 & 0.54 & 0.50 \\
\hline Dy & 2.88 & 4.08 & 5.53 & 3.99 & 1.62 & 4.99 & 6.70 & 3.07 & 2.96 & 2.82 \\
\hline Ho & 0.51 & 0.72 & 1.03 & 0.76 & 0.30 & 1.05 & 1.31 & 0.52 & 0.47 & 0.51 \\
\hline Er & 1.38 & 2.08 & 3.03 & 2.27 & 0.84 & 3.16 & 3.78 & 1.33 & 1.32 & 1.44 \\
\hline $\mathrm{Tm}$ & 0.20 & 0.30 & 0.47 & 0.34 & 0.12 & 0.54 & 0.58 & 0.19 & 0.20 & 0.22 \\
\hline $\mathrm{Yb}$ & 1.21 & 1.92 & 2.89 & 2.19 & 0.85 & 3.57 & 3.63 & 1.23 & 1.15 & 1.50 \\
\hline $\mathrm{Lu}$ & 0.16 & 0.29 & 0.40 & 0.37 & 0.15 & 0.49 & 0.55 & 0.18 & 0.14 & 0.25 \\
\hline
\end{tabular}




\begin{tabular}{|c|c|c|c|c|c|c|}
\hline $\begin{array}{l}\text { Sample \# } \\
\text { Pluton } \\
\text { Age }\end{array}$ & $\begin{array}{l}\text { 12-SHM-12 } \\
\text { McKiel Lake } \\
\text { Middle } \\
\text { Ordovician }\end{array}$ & $\begin{array}{l}\text { 12-SHM-13 } \\
\text { McKiel Lake } \\
\text { Middle } \\
\text { Ordovician }\end{array}$ & $\begin{array}{c}\text { 12-SHM-21 } \\
\text { Little Clearwater } \\
\text { Middle } \\
\text { Ordovician }\end{array}$ & $\begin{array}{c}\text { 12-SHM-22 } \\
\text { Little Clearwater } \\
\text { Middle } \\
\text { Ordovician }\end{array}$ & $\begin{array}{c}\text { 11-SHM-44 } \\
\text { Little Clearwater } \\
\text { Middle } \\
\text { Ordovician }\end{array}$ & $\begin{array}{c}\text { 11-SHM-45 } \\
\text { Little Clearwater } \\
\text { Middle } \\
\text { Ordovician }\end{array}$ \\
\hline $\mathrm{SiO}_{2}$ & 72.95 & 78.10 & 74.98 & 74.94 & 79.56 & 74.23 \\
\hline $\mathrm{TiO}_{2}$ & 0.25 & 0.14 & 0.34 & 0.32 & 0.14 & 0.31 \\
\hline $\mathrm{Al}_{2} \mathrm{O}_{3}$ & 13.82 & 11.69 & 12.44 & 12.74 & 12.80 & 12.60 \\
\hline $\mathrm{Fe}_{2} \mathrm{O}_{3}$ & 2.02 & 1.26 & 2.16 & 2.15 & 0.71 & 2.15 \\
\hline $\mathrm{MnO}$ & 0.04 & 0.02 & 0.04 & 0.05 & 0.01 & 0.04 \\
\hline $\mathrm{MgO}$ & 0.32 & 0.23 & 0.68 & 0.43 & 0.25 & 0.42 \\
\hline $\mathrm{CaO}$ & 1.05 & 0.56 & 0.64 & 0.63 & 0.12 & 0.59 \\
\hline $\mathrm{Na}_{2} \mathrm{O}$ & 2.73 & 3.22 & 3.36 & 3.18 & 0.12 & 3.53 \\
\hline $\mathrm{K}_{2} \mathrm{O}$ & 6.00 & 4.04 & 3.76 & 4.57 & 4.61 & 3.63 \\
\hline $\mathrm{P}_{2} \mathrm{O}_{5}$ & 0.22 & 0.05 & 0.07 & 0.07 & 0.13 & 0.07 \\
\hline LOI & 0.87 & 0.55 & 0.87 & 0.67 & 2.13 & 0.73 \\
\hline TOTAL & 100.20 & 99.85 & 99.36 & 99.75 & 100.60 & 98.29 \\
\hline Ag & $<0.3$ & 0.4 & $<0.3$ & $<0.3$ & $<0.3$ & 0.3 \\
\hline As & $<0.5$ & $<0.5$ & $<0.5$ & $<0.5$ & 46.7 & $<0.5$ \\
\hline $\mathrm{Au}$ & 18 & $<2$ & $<2$ & $<2$ & $<2$ & $<2$ \\
\hline $\mathrm{Ba}$ & 591 & 279 & 248 & 370 & 186 & 333 \\
\hline $\mathrm{Be}$ & 3 & 3 & 3 & 3 & 1 & 4 \\
\hline $\mathrm{Bi}$ & $<0.1$ & $<0.1$ & 0.2 & 0.4 & 0.6 & 0.3 \\
\hline $\mathrm{Cd}$ & $<0.5$ & $<0.5$ & $<0.5$ & $<0.5$ & $<0.5$ & $<0.5$ \\
\hline Co & 2.0 & 1.0 & 3.0 & 3.0 & 1.0 & 3.0 \\
\hline $\mathrm{Cr}$ & 25 & 27 & 19 & 21 & 17 & 14 \\
\hline Cs & 2.4 & 1.2 & 3.8 & 4.5 & 12.4 & 4.4 \\
\hline $\mathrm{Cu}$ & 5 & 2 & 7 & 2 & 9 & 2 \\
\hline $\mathrm{Ga}$ & 17 & 16 & 17 & 17 & 12 & 17 \\
\hline $\mathrm{Ge}$ & 1.8 & 1.6 & 2.1 & 2.1 & 2.0 & 2.1 \\
\hline $\mathrm{Hf}$ & 3.1 & 5.1 & 4.7 & 5.1 & 2.7 & 4.6 \\
\hline In & $<0.1$ & $<0.1$ & $<0.1$ & $<0.1$ & $<0.1$ & $<0.1$ \\
\hline Mo & $<2.0$ & $<2.0$ & $<2.0$ & $<2.0$ & $<2.0$ & $<2.0$ \\
\hline $\mathrm{Nb}$ & 4.4 & 5.2 & 15.6 & 15.1 & 3.5 & 16.7 \\
\hline $\mathrm{Ni}$ & 4 & 2 & 4 & 4 & 3 & 4 \\
\hline $\mathrm{Pb}$ & 29 & 26 & 15 & 16 & 20 & 12 \\
\hline $\mathrm{Rb}$ & 180 & 134 & 159 & 192 & 190 & 153 \\
\hline S & 0.008 & 0.003 & 0.004 & 0.004 & 0.002 & 0.003 \\
\hline $\mathrm{Sb}$ & $<0.2$ & $<0.2$ & $<0.2$ & $<0.2$ & 11.0 & 0.4 \\
\hline $\mathrm{Sc}$ & 5.0 & 3.0 & 6.0 & 6.0 & 4.0 & 5.0 \\
\hline Sn & 4.0 & 8.0 & 5.0 & 4.0 & $<1$ & 6.0 \\
\hline $\mathrm{Sr}$ & 90 & 42 & 55 & 55 & 26 & 49 \\
\hline $\mathrm{Ta}$ & 0.75 & 0.88 & 1.71 & 1.79 & 0.47 & 1.94 \\
\hline Th & 10.60 & 20.80 & 21.00 & 23.60 & 10.90 & 18.60 \\
\hline $\mathrm{Tl}$ & 0.75 & 0.62 & 0.69 & 0.90 & 0.75 & 0.73 \\
\hline $\mathrm{U}$ & 3.78 & 2.92 & 4.73 & 3.79 & 3.11 & 4.80 \\
\hline $\mathrm{V}$ & 19 & 7 & 26 & 25 & 13 & 25 \\
\hline $\mathrm{W}$ & $<0.5$ & $<0.5$ & 1.1 & 1.4 & 1.5 & $<0.5$ \\
\hline $\mathrm{Y}$ & 53.3 & 53.7 & 42.5 & 38.9 & 27.1 & 40.2 \\
\hline $\mathrm{Zn}$ & 32 & 22 & 19 & 29 & 15 & 18 \\
\hline $\mathrm{Zr}$ & 120 & 149 & 186 & 181 & 80 & 158 \\
\hline $\mathrm{La}$ & 18.50 & 27.50 & 36.60 & 39.60 & 12.00 & 33.90 \\
\hline $\mathrm{Ce}$ & 40.60 & 58.20 & 76.50 & 82.20 & 25.60 & 68.20 \\
\hline $\operatorname{Pr}$ & 4.93 & 6.77 & 8.66 & 9.27 & 3.02 & 7.90 \\
\hline $\mathrm{Nd}$ & 20.20 & 24.40 & 32.50 & 33.70 & 11.10 & 28.90 \\
\hline $\mathrm{Sm}$ & 5.56 & 5.26 & 6.61 & 6.57 & 2.56 & 5.81 \\
\hline $\mathrm{Eu}$ & 1.13 & 0.40 & 0.79 & 0.74 & 0.37 & 0.64 \\
\hline Gd & 6.01 & 5.40 & 6.33 & 6.16 & 2.96 & 5.77 \\
\hline $\mathrm{Tb}$ & 1.23 & 1.06 & 1.05 & 1.04 & 0.55 & 0.98 \\
\hline Dy & 8.18 & 7.21 & 6.43 & 6.45 & 3.89 & 6.03 \\
\hline Ho & 1.63 & 1.54 & 1.26 & 1.31 & 0.82 & 1.23 \\
\hline $\mathrm{Er}$ & 4.97 & 4.87 & 3.62 & 3.83 & 2.54 & 3.56 \\
\hline $\mathrm{Tm}$ & 0.82 & 0.79 & 0.57 & 0.59 & 0.41 & 0.56 \\
\hline $\mathrm{Yb}$ & 5.15 & 5.17 & 3.90 & 3.95 & 2.72 & 3.69 \\
\hline $\mathrm{Lu}$ & 0.72 & 0.72 & 0.61 & 0.60 & 0.39 & 0.53 \\
\hline
\end{tabular}

